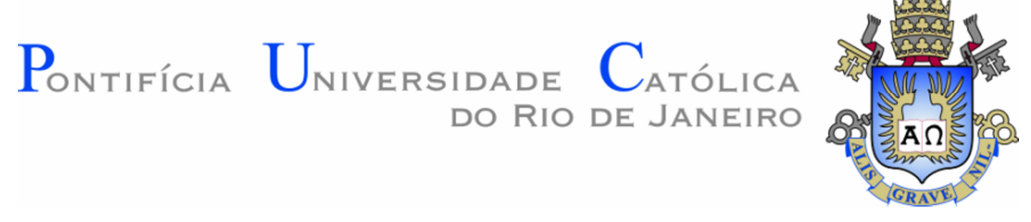

Carlos Alberto Castañeda Olivera

\title{
Flotação do sistema hematita-quartzo utilizando o biossurfactante solúvel produzido por Rhodococcus erythropolis
}

Tese de Doutorado

Tese apresentada ao Programa de Pós-Graduação em Engenharia de Materiais e de Processos Químicos e Metalúrgicos da PUC-Rio como requisito parcial para obtenção do grau de Doutor em Engenharia de Materiais e de Processos Químicos e Metalúrgicos.

Orientador: Prof. Maurício Leonardo Torem Co-orientador: Dr. Antonio Gutiérrez Merma

Rio de Janeiro

Abril de 2018 

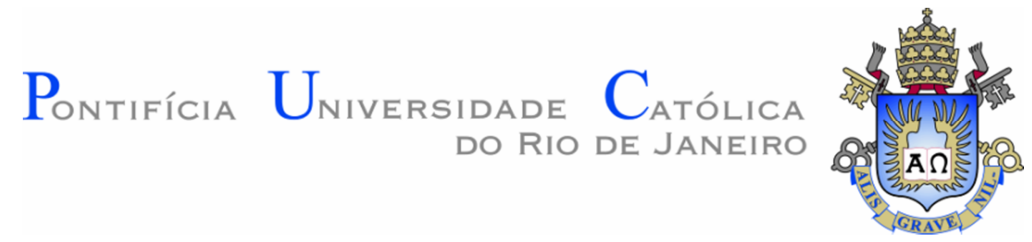

Carlos Alberto Castañeda Olivera

\section{Flotação do sistema hematita-quartzo utilizando o biossurfactante solúvel produzido por Rhodococcus erythropolis}

Tese apresentada como requisito parcial para obtenção do grau de Doutor pelo Programa de Pós-Graduação em Engenharia de Materiais e de Processos Químicos e Metalúrgicos da PUC-Rio. Aprovada pela Comissão Examinadora abaixo assinada.

Prof. Maurício Leonardo Torem

Orientador

Departamento de Engenharia Química e de Materiais - PUC-Rio

Dr. Antonio Gutiérrez Merma

Co-orientador

Departamento de Engenharia Química e de Materiais - PUC-Rio

Dr. Ronald Rojas Hacha

Departamento de Engenharia Química e de Materiais - PUC-Rio

Prof. Brunno Ferreira dos Santos Departamento de Engenharia Química e de Materiais - PUC-Rio

Dr. ${ }^{a}$ Flávia Paulucci Cianga Silvas Instituto Tecnológico Vale - ITV

Prof. Hudson Jean Bianquini Couto Centro de Tecnologia Mineral - CETEM/MCTI

Prof. Marcio da Silveira Carvalho

Coordenador Setorial do Centro Técnico e Científico - PUC-Rio

Rio de Janeiro, 04 de Abril de 2018 
Todos os direitos reservados. É proibida a reprodução total ou parcial do trabalho sem autorização da universidade, do autor e do orientador.

\section{Carlos Alberto Castañeda Olivera}

Graduou-se em Engenharia Metalúrgica pela Universidade Nacional José Faustino Sanchez Carrión (UNJFSC) em 2008. Fez Mestrado em Engenharia de Materiais e de Processos Químicos e Metalúrgicos da PUC-Rio. Possui o MBA em Gerenciamento de Projetos pela IAG-Escola de Negócios da PUC-Rio. Tem experiência na área de Processamento de Minérios Polimetálicos, Extração de Ouro e Laboratório Metalúrgico. Atualmente, pesquisa na área de Tecnologia Mineral e Ambiental.

Ficha Catalográfica

Castañeda Olivera, Carlos Alberto

Flotação do sistema hematita-quartzo utilizando o biossurfactante solúvel produzido por Rhodococcus erythropolis / Carlos Alberto Castañeda Olivera; orientador: Maurício Leonardo Torem; co-orientador: Antonio Gutiérrez Merma. - 2018.

148 f. : il. color. ; $30 \mathrm{~cm}$

Tese (doutorado)-Pontifícia Universidade Católica do Rio de Janeiro, Departamento de Engenharia Química e de Materiais, 2018.

Inclui bibliografia

1. Engenharia de Materiais - Teses. 2. Engenharia Química - Teses. 3. Biossurfactante. 4. Biorreagente. 5. Microflotação. 6. Hematita. 7. Quartzo. I. Torem, Maurício Leonardo. II. Gutiérrez Merma, Antonio. III. Pontifícia Universidade Católica do Rio de Janeiro. Departamento de Engenharia Química e de Materiais. IV. Título.

CDD: 620.11 
Para meus pais: Dionila e Santos (in memorian), por estarem sempre presentes em minha vida. 


\section{Agradecimentos}

A lista de agradecimentos por mais uma vitória na minha vida é grande, porém não posso deixar de citar pessoas que contribuíram direta ou indiretamente nessa etapa tão importante.

Em primeiro lugar, a Deus, pelo maravilhoso dom da vida e, por me dar saúde, força, proteção e sabedoria.

Aos meus pais Dionila Olivera Valdez e Santos Castañeda Deza (in memorian), por participarem da minha existência, pela educação e apoio.

Aos meus irmãos e familiares, que mesmo de longe, sempre estiveram presentes em minha caminhada acadêmica, ajudando-me e motivando-me a seguir em frente.

Ao meu orientador Prof. Dr. Maurício Leonardo Torem pelo apoio e confiança depositada e, aos professores do Departamento de Engenharia Química e de Materiais (DEQM) da Pontifícia Universidade Católica do Rio de Janeiro (PUCRio).

Aos Drs. Antonio Gutiérrez Merma (co-orientador) e Ronald Rojas Hacha pela amizade e ajuda durante o desenvolvimento da minha tese.

À Prof. ${ }^{a}$ Dr. $^{\text {a }}$ Renata Antoun Simão e ao Dr. Meysam M. Keley da COPPE/UFRJ, pelo apoio com as medidas do ângulo de contato dos minerais.

À Dr. ${ }^{a}$ Flávia Paulucci Cianga Silvas pela ajuda e informações técnicas 
prestadas na elaboração deste trabalho.

À minha grande amiga Eliana Paola Marin do Departamento de Engenharia Mecânica pela amizade e suporte nas medições da tensão superficial.

À minha amiga Vanessa Figueiredo da Silva Coelho por seu apoio na revisão cuidadosa de língua portuguesa em minha tese.

Aos companheiros de trabalho do Grupo de Pesquisa em Tecnologia Mineral e Ambiental (GPTMA) do Departamento de Engenharia Química e de Materiais (DEQM) da Pontifícia Universidade Católica do Rio de Janeiro (PUC-Rio).

Aos meus colegas e queridos amigos da casa XXI do Departamento de Engenharia Química e de Materiais (DEQM) pela amizade e ajuda durante o curso de doutorado.

À Coordenação de Aperfeiçoamento de Pessoal de Nível Superior (CAPES), ao Conselho Nacional de Desenvolvimento Científico e Tecnológico $(\mathrm{CNPq})$ e à Pontifícia Universidade Católica do Rio de Janeiro (PUC-Rio) pelo auxilio prestado e pela concessão de bolsas, que tornou viável a execução desta pesquisa.

Ao ITV-VALE pela oportunidade de ter participado no projeto e pelo suporte financeiro.

Ao Centro de Tecnologia Mineral (CETEM/MCTI) pela grande colaboração na caracterização das amostras minerais.

Aos problemas vividos e superados, com os quais eu aprendi muito.

Ao Brasil e as suas pessoas amáveis por ter compartilhado esses anos todos.

Enfim, a todos vocês e a todas aquelas pessoas que de alguma outra forma participaram no desenvolvimento da minha tese, têm minha eterna gratidão. 


\section{Resumo}

Olivera, Carlos Alberto Castañeda; Torem, Maurício Leonardo; Merma, Antonio Gutiérrez. Flotação do sistema hematita-quartzo utilizando o biossurfactante solúvel produzido por Rhodococcus erythropolis. Rio de Janeiro, 2018. 148p. Tese de Doutorado - Departamento de Engenharia Química e de Materiais, Pontifícia Universidade Católica do Rio de Janeiro.

A busca por novos reagentes de baixa toxicidade e de alta biodegradabilidade tem sido estimulada. Como resultado, diversas pesquisas vêm desenvolvendo biorreagentes, dentre eles os biossurfactantes. Os biossurfactantes são moléculas de origem microbiana que possuem ação superficial. Essas moléculas, com propriedades anfifílicas, são produzidas biologicamente e têm aplicação em diversos setores industriais. Assim sendo, esta pesquisa teve como objetivo estudar a flotação do sistema hematita-quartzo utilizando o biossurfactante solúvel produzido por Rhodococcus erythropolis como biorreagente coletor. O biossurfactante (BS) foi caracterizado por análises químicas para determinar a percentagem de proteínas, carboidratos e lipídeos e, suas propriedades físico-químicas foram determinadas por tensão superficial e concentração micelar crítica (CMC). Os minerais e sua interação com o BS foram caracterizados por medições de potencial zeta, medidas de ângulo de contato e espectroscopia no infravermelho (FTIR) para determinar suas propriedades eletrocinéticas, hidrofobicidade e grupos funcionais, respectivamente. Os resultados de adsorção revelaram maior adsorção do biossurfactante na superfície de hematita do que na superfície de quartzo e, isto foi confirmado por analises FTIR e testes de microflotação. Os resultados de microflotação de hematita e de quartzo foram maiores em $\mathrm{pH} 3$ e com concentração de BS de $100 \mathrm{mg} / \mathrm{L}$, com recuperações em torno de 99,88\% e $31,05 \%$, respectivamente e, os mesmos foram analisados estatisticamente para obter uma função polinomial representativa da microflotação. Os testes de microflotação do sistema hematita-quartzo mostraram que o biossurfactante é mais seletivo com hematita do que quartzo. O estudo cinético mostrou que os dados experimentais da microflotação de hematita foram ajustados quanto ao modelo cinético de primeira ordem como ao modelo cinético de ordem 
fracionária, enquanto os dados experimentais da microflotação de quartzo foram ajustados ao modelo cinético de ordem fracionária. Finalmente, os resultados deste trabalho evidenciaram que a utilização do biossurfactante solúvel produzido por Rhodococcus erythropolis como reagente coletor no sistema hematita-quartzo foi viável, demonstrando o seu grande potencial e mostrandose bastante promissor para uma futura aplicação na indústria da flotação mineral.

\section{Palavras chave}

Biossurfactante; biorreagente; microflotação; hematita; quartzo. 


\section{Abstract}

Olivera, Carlos Alberto Castañeda; Torem, Maurício Leonardo (Advisor); Merma, Antonio Gutiérrez (Co-advisor). Flotation of the hematitequartz system using the soluble biosurfactant produced by Rhodococcus erythropolis. Rio de Janeiro, 2018. 148p. Tese de Doutorado - Departamento de Engenharia Química e de Materiais, Pontifícia Universidade Católica do Rio de Janeiro.

The search for new reagents of low toxicity and high biodegradability has been stimulated. As a result, several researches have been developing bioreagents, among them biosurfactants. Biosurfactants are molecules of microbial origin that have surface action. These molecules, with amphiphilic properties, are produced biologically and have application in various industrial sectors. Therefore, this research aimed to study the flotation of the hematitequartz system using the soluble biosurfactant produced by Rhodococcus erythropolis as a collector bioreagent. The biosurfactant (BS) was characterized by chemical analysis to determine the percentage of proteins, carbohydrates and lipids and its physicochemical properties were determined by surface tension and critical micellar concentration (CMC). The minerals and their interaction with BS were characterized by measurements of zeta potential, contact angle measurements and infrared spectroscopy (FTIR) to determine their electrokinetic properties, hydrophobicity and functional groups, respectively. The adsorption results revealed higher adsorption of the biosurfactant onto the hematite surface than onto quartz surface and this was confirmed by FTIR analysis and microflotation tests. The results of hematite and quartz microflotation were higher at $\mathrm{pH} 3$ and at the concentration of $100 \mathrm{mg} / \mathrm{L}$, with recoveries around $99.88 \%$ and $31.05 \%$, respectively, and they were analyzed statistically to obtain a polynomial function representative of microflotation. The microflotation tests of the hematite-quartz system showed that the biosurfactant is more selective with hematite than quartz. The kinetic study showed that the experimental data of hematite microflocation were adjusted to both the first order kinetic model and the kinetic model of non-integral order, while the experimental data of the quartz microflotation were adjusted to the kinetic model of non-integral order. Finally, the results of this work showed that the use of the 
soluble biosurfactant produced by Rhodococcus erythropolis as a collector reagent in the hematite-quartz system was feasible, demonstrating its great potential and showing quite promising for a future application in the mineral flotation industry.

\section{Keywords}

Biosurfactant; bioreagent; microflotation; hematite; quartz. 


\section{Sumário}

1 Introdução 22

2 Objetivos e relevância do trabalho 24

2.1. Objetivo geral 24

2.2. Objetivos específicos 24

2.3. Relevância do trabalho 25

3 Revisão bibliográfica 26

3.1. Minerais em estudo: Hematita e quartzo 26

3.2. Flotação mineral 27

3.2.1. Flotação em espuma $\quad 27$

3.2.2. Flotação de minério de ferro 29

3.3. Bioflotação mineral 30

3.3.1. Aspectos gerais $\quad 30$

3.3.2. Características das bactérias na bioflotação mineral 30

3.3.3. Composição superficial dos microrganismos 31

3.3.4. Biorreagentes na flotação de minério de ferro 32

3.3.5. Rhodococcus erythropolis 33

3.3.6. Propriedades eletrocinéticas dos biorreagentes 35

3.3.7. Adsorção dos biorreagentes 40

3.3.8. Molhabilidade e ângulo de contato 41

3.3.9. Cinética de flotação mineral 43

3.4. Surfactantes e Biossurfactantes 45

3.4.1. Surfactantes 45

3.4.2. Biossurfactantes 48

3.4.3. Classificação dos biossurfactantes 48

3.4.4. Microrganismos produtores de biossurfactantes 52

3.4.5. Propriedades e vantagens dos biossurfactantes 53

3.4.6. Estudos de flotação mineral usando biossurfactantes como biorreagente 56 
Materiais e Métodos

3.5. Preparação e caracterização das amostras minerais 58

3.6. Cultivo e crescimento do Rhodococcus erythropolis 59

3.7. Caracterização do biossurfactante produzido por Rhodococcus erythropolis $\quad 61$

3.7.1. Processo de extração do biossurfactante 61

3.7.2. Determinação de proteínas, carboidratos e lipídeos presentes no biossurfactante solúvel 63

3.7.3. Determinação da tensão superficial do biossurfactante solúvel

3.8. Ensaios de adsorção 64

3.9. Comportamento dos minerais antes e após interação 64

3.9.1. Medidas de potencial zeta 64

3.9.2. Medidas de ângulo de contato 65

3.9.3. Espectroscopia no infravermelho (FTIR) 66

3.10. Ensaios de microflotação. 66

3.11. Cinética de microflotação 69

4 Resultados e discussão $\quad 71$

4.1. Preparação e caracterização das amostras minerais 71

4.2. Caracterização do biossurfactante produzido pela bactéria Rhodococcus erythropolis 73

4.2.1. Processo de extração do biossurfactante 73

4.2.2. Determinação de proteínas, carboidratos e lipídeos presentes no biossurfactante solúvel. 74

4.2.3. Determinação da tensão superficial do biossurfactante solúvel $\quad 76$

4.2.4. Espectroscopia no infravermelho do biossurfactante solúvel 78

4.3. Comportamento dos minerais antes e após interação com o biossurfactante 79

4.3.1. Estudos de potencial zeta 79

4.3.2. Medidas de ângulo de contato 83

4.3.3. Espectroscopia no infravermelho 86

4.4. Estudos de adsorção 90 
4.4.1. Adsorção do biossurfactante na superfície da hematita 90

4.4.2. Adsorção do biossurfactante na superfície do quartzo 92

4.5. Ensaios de microflotação 93

4.5.1. Arraste mecânico 93

4.5.2. Microflotação de hematita 94

4.5.3. Microflotação de quartzo 100

4.5.4. Microflotação do sistema hematita-quartzo 106

4.6. Cinética de microflotação 114

4.6.1. Cinética da flotabilidade da hematita 114

4.6.2. Cinética da flotabilidade do quartzo 116

5 Conclusões 119

6 Recomendações para futuros trabalhos 122

7 Referências bibliográficas $\quad 123$

8 Apêndices 135 


\section{Lista de figuras}

Figura 1. Princípio de flotação em espuma (adaptado de Wills e Finch, 2015).

Figura 2. Mecanismos de recuperação (Santos, 2014).

Figura 3. Parede celular da bactéria Gram positiva e bactéria Gram negativa (Talaro e Chess, 2017).

Figura 4. Células Rhodococcus erythropolis (Olivera, 2014).

Figura 5. Efeito de Rhodococcus erythropolis na recuperação de hematita, quartzo, apatita e caulinita, pH 6 (Adaptado de Yang et al., 2013b).

Figura 6. Flotabilidade da hematita em função do tempo: $\mathrm{pH} 6 \mathrm{e}$ concentração de biomassa de 200 mg/L (Olivera, 2014).

Figura 7. Estrutura da dupla camada elétrica (Santos, 2014)

Figura 8. Perfis de potencial zeta com eletrólito indiferente: $\mathrm{NaCl}$ $10^{-3} \mathrm{~mol} / \mathrm{L}$ (Olivera, 2014).

Figura 9. Curvas de potencial zeta para o Rhodococcus erythropolis, hematita, quartzo, apatita e caulinita (Adaptado de Yang et al., 2013b).

Figura 10. Representação clássica do ângulo de contato e forças de tensão superficial (Adaptado de Wills e Finch 2015).

Figura 11. Fórmulas desenvolvidas de alguns surfactantes comuns (Adaptado de Salager, 2002).

Figura 12. Tensão superficial, tensão interfacial e solubilidade em função da concentração de surfactante (Pacheco, 2008). 
Figura 13. Características dos biossurfactantes úteis em várias aplicações (Adaptado de Khan et al., 2015).

Figura 14. Fluxograma detalhado da preparação das amostras minerais.

Figura 15. Colônias de Rhodococcus erythropolis em placa de petri.

Figura 16. Crescimento bacteriano

Figura 17. Fluxograma do protocolo de extração do biossurfactante com etanol.

Figura 18- Seções polidas das amostras quartzo e hematita.

Figura 19. Sistema de microflotação: a) pH-metro, b) Bomba de vácuo e compressor, c) Agitador magnético, d) Tubo de Hallimond modificado, e) Rotâmetro e f) Bolhômetro.

Figura 20. Difratograma da amostra de hematita.

Figura 21. Difratograma da amostra de quartzo.

Figura 22. Biossurfactante extraído do Rhodococcus erythropolis:

a) Biossurfactante bruto e b) Biossurfactante solúvel.

Figura 23. Tensão superficial do biorreagente em função da concentração do biossurfactante: $\mathrm{pH} 3$.

Figura 24. Tensão superficial do biorreagente em função do $\mathrm{pH}$ (concentração do biossurfactante: $100 \mathrm{mg} / \mathrm{L}$ ).

Figura 25. Espectro de FTIR de transmitância do biossurfactante.

Figura 26. Perfis de potencial zeta da hematita em diferentes concentrações de eletrólito indiferente. 
Figura 27. Perfis de potencial zeta da hematita antes e após a interação com o biossurfactante. Concentração de eletrólito indiferente: $\mathrm{NaCl} 10^{-2} \mathrm{~mol} / \mathrm{L}$.

Figura 28. Perfil de potencial zeta do quartzo em diferentes concentrações de eletrólito indiferente.

Figura 29. Perfis de potencial zeta do quartzo antes e após a interação com o biossurfactante. Concentração de eletrólito indiferente: $\mathrm{NaCl} 10^{-2} \mathrm{~mol} / \mathrm{L}$.

Figura 30. Medidas de ângulo de contato da hematita após interação com obiossurfactante. Concentração do biossurfactante: $100 \mathrm{mg} / \mathrm{L}$.

Figura 31. Medidas de ângulo de contato do quartzo após interação com 0 biossurfactante. Concentração do biossurfactante: $100 \mathrm{mg} / \mathrm{L}$.

Figura 32. Espectro de FTIR de transmitância do mineral hematita.

Figura 33. Espectro de FTIR de transmitância do mineral hematita (antes e após interação com o biossurfactante).

Figura 34. Espectro de FTIR de transmitância do mineral quartzo.

Figura 35. Espectro de FTIR de transmitância do mineral quartzo (antes e após interação com o biossurfactante).

Figura 36. Influência do pH na adsorção do biossurfactante sobre a superfície da hematita.

Figura 37. Influência do pH na adsorção do biossurfactante sobre a superfície do quartzo.

Figura 38. Arraste mecânico da hematita e quartzo, em função do $\mathrm{pH}$. 
Figura 39. Efeito do $\mathrm{pH}$ na microflotação de hematita. Concentração do biossurfactante: $10 \mathrm{mg} / \mathrm{L}$.

Figura 40. Efeito da concentração do biossurfactante na microflotação de hematita. pH: 3 .

Figura 41. a) Superfície de resposta 3D da microflotação de hematita em função da concentração do biossurfactante e do $\mathrm{pH}$ da solução; b) Gráfico de contorno 3D da microflotação de hematita em função da concentração do biossurfactante e do pH da solução.

Figura 42. Efeito do $\mathrm{pH}$ na microflotação de quartzo. Concentração do biossurfactante: $10 \mathrm{mg} / \mathrm{L}$.

Figura 43. Efeito da concentração do biossurfactante na microflotação de quartzo. pH: 3.

Figura 44. a) Superfície de resposta 3D da microflotação de quartzo em função da concentração do biossurfactante e do $\mathrm{pH}$ da solução; b) Gráfico de contorno 3D da microflotação de quartzo em função da concentração do biossurfactante e do $\mathrm{pH}$ da solução.

Figura 45. Efeito da concentração de metassilicato de sódio na depressão de quartzo. Concentração do biossurfactante de 100 $\mathrm{mg} / \mathrm{L}$ e $\mathrm{pH}$ da solução $=3$.

Figura 46. Microflotação do sistema hematita-quartzo e teor de ferro em função do pH da solução. Concentração do metassilicato de sódio de $100 \mathrm{mg} / \mathrm{L}$ e concentração do biossurfactante de 100 mg/L. Relação da mistura hematita-quartzo (1:1).

Figura 47. Recuperação da hematita e do quartzo em função do pH da solução. Concentração do metassilicato de sódio de 100 $\mathrm{mg} / \mathrm{L}$ e concentração do biossurfactante de $100 \mathrm{mg} / \mathrm{L}$. Relação da mistura hematita-quartzo (1:1). 
Figura 48. Microflotação do sistema hematita-quartzo e teor de ferro em função da concentração do metassilicato de sódio. Concentração do biossurfactante de 100 mg/L e pH da solução = 3. Relação da mistura hematita-quartzo (1:1).

Figura 49. Recuperação da hematita e do quartzo em função da concentração do metassilicato de sódio. Concentração do biossurfactante de $100 \mathrm{mg} / \mathrm{L}$ e $\mathrm{pH}$ da solução = 3 . Relação da mistura hematita-quartzo $(1: 1)$.

Figura 50. Flotabilidade de hematita em função do tempo. Concentração do biossurfactante: $10 \mathrm{mg} / \mathrm{L}$ e pH = 3 .

Figura 51. Ajuste linear da cinética de microflotação de hematita usando tanto o modelo de primeira ordem como o modelo de ordem fracionária.

Figura 52. Flotabilidade de quartzo em função do tempo. Concentração do biossurfactante: $10 \mathrm{mg} / \mathrm{L}$ e $\mathrm{pH}=3$.

Figura 53. Ajuste linear da cinética de microflotação de quartzo usando o modelo de ordem fracionária.

Figura 54. Curva padrão de proteínas

Figura 55. Curva padrão de carboidratos

Figura 56. Curva padrão do biossurfactante

Figura 57. Ajuste linear da cinética de microflotação de hematita usando o modelo de segunda ordem

Figura 58. Ajuste linear da cinética de microflotação de quartzo usando o modelo de primeira ordem

Figura 59. Ajuste linear da cinética de microflotação de quartzo usando o modelo de segunda ordem 


\section{Lista de tabelas}

Tabela 1. Grupos ionizáveis encontrados na superfície bacteriana e suas constantes de dissociação (Poortinga et al., 2002).

Tabela 2. Bactérias usadas na flotação de hematita e de quartzo

Tabela 3. Fundamentos dos métodos de sorção (Naja e Volesky, 2011)

Tabela 4. Modelos cinéticos de flotação mineral (Olivera et al., 2017).

Tabela 5. Classificação dos biossurfactantes produzidos por diferentes microrganismos (Nitschke e Pastore 2002).

Tabela 6. Testes e frações granulométricas

Tabela 7. Meio de cultura TSB

Tabela 8. Condições experimentais empregadas nos testes de microflotação

Tabela 9. Parâmetros utilizados na determinação da cinética de microflotação mineral.

Tabela 10. Composição química das amostras de hematita e quartzo por fluorescência de raios-X

Tabela 11. Composição do biossurfactante solúvel.

Tabela 12. Ângulo de contato de hematita e quartzo sem interação com o biossurfactante. 
Tabela 13. Flotabilidade (\%) da hematita nos ensaios de microflotação utilizando o biossurfactante solúvel produzido por Rhodococcus erythropolis

Tabela 14. Coeficientes do modelo de regressão polinomial da microflotação de hematita.

Tabela 15. Flotabilidade (\%) do quartzo nos ensaios de microflotação utilizando o biossurfactante solúvel produzido por Rhodococcus erythropolis

Tabela 16. Coeficientes do modelo de regressão polinomial da microflotação de quartzo.

Tabela 17. Microflotação do sistema hematita-quartzo em diferentes relações de mistura.

Tabela 18. Constantes cinéticas da microflotação de hematita

Tabela 19. Constantes cinéticas da microflotação de quartzo 
"Não confunda derrotas com fracasso nem vitórias com sucesso. Na vida de um campeão sempre haverá algumas derrotas, assim como na vida de um perdedor sempre haverá vitórias. A diferença é que, enquanto os campeões crescem nas derrotas, os perdedores se acomodam nas vitórias."

Roberto Shinyashiki 


\section{Introdução}

A utilização de microrganismos e/ou seus produtos metabólicos como reagentes, em particular, coletores, espumantes e modificadores (que podem ser depressores, ativadores e reguladores de $\mathrm{pH}$, etc) em operações de processamento mineral, vem se tornando muito atraente, por apresentar um grande potencial tecnológico, aceitabilidade ambiental, e flexibilidade de escolha para sua seletividade mineral e também para o processamento de partículas minerais finas e ultrafinas. Além disso, estes novos reagentes de flotação poderiam alcançar menores custos operacionais no processamento de minérios de baixo grau (AbdelKhalek et al., 2015; Mesquita et al., 2003; Dwyer et al., 2012; Merma et al., 2013).

Em bioflotação, os microrganismos e/ou seus produtos metabólicos podem modificar a superfície mineral, tanto direta como indiretamente. $\mathrm{O}$ mecanismo direto envolve a adesão direta das células microbianas as partículas minerais, enquanto o mecanismo indireto refere-se aos produtos do metabolismo ou frações solúveis da célula que agem como reagentes ativos na superfície. Ambas as interações levam a alterações na química da superfície, tornando-a hidrofílica ou hidrofóbica dependendo do caráter da bactéria (Merma et al., 2013).

A revisão da literatura mostrou que diversas bactérias têm sido utilizadas na bioflotação de hematita e quartzo, ressaltam-se entre elas: Mycobacterium phlei (Dubel et al., 1992; Yang et al., 2007), Bacillus polymyxa (Deo \& Natarajan, 1997; Shashikala \& Raichur, 2002), Paenibacillus polymyxa (Deo \& Natarajan, 1998), Desulfovibrio desulfuricans (Sabari \& Natarajan, 2010), Rhodococcus opacus (Mesquita et al., 2003), Bacillus subtilis (Sarvamangala \& Natarajan, 2011), Rhodococcus ruber (Lopez et al., 2015) e Rhodococcus erythropolis (Olivera et al., 2017; Yang et al., 2013a).

Os produtos microbianos tais como biossurfactantes, são aplicados na flotação de minerais como biorreagentes, que vêm sendo uma alternativa de tecnologia ecologicamente aceitável (Didyk \& Sadowski, 2012). Esses 
biossurfactantes são compostos bioquímicos que possuem uma estrutura comum: uma porção lipofílica usualmente composta por cadeia hidrocarbônica de um ou mais ácidos graxos, que podem ser saturados, insaturados, hidroxilados ou ramificados, ligados a uma porção hidrofílica, que pode ser um éster, um grupo hidróxi, fosfato, carboxilato ou carboidrato (Nitschke \& Pastore, 2002).

Desta forma, baseando-se na viabilidade do uso de Rhodococcus erythropolis como biorreagente coletor de hematita, o presente trabalho busca explorar sua capacidade metabólica no que diz respeito à produção de biossurfactante, a fim de se obter melhoras na flotação do sistema hematitaquartzo.

Assim, esta tese está organizada em sete capítulos. O capitulo 1 é a presente introdução. No Capitulo 2 são apresentados os objetivos e relevância que nortearam o desenvolvimento deste trabalho. No Capítulo 3 é apresentada a revisão bibliográfica sobre os fundamentos do processo de flotacão e bioflotação mineral, principalmente, para minerais de hematita e de quartzo, assim como uma revisão de literatura sobre surfactantes e biossurfactantes. Posteriormente, no Capítulo 4, descrevem-se as metodologias utilizadas para a produção do biossurfactante por Rhodococcus erythropolis, caracterização dos minerais e do biorreagente, ensaios de microflotação e cinética de microflotação. No Capítulo 5, os resultados são exibidos e discutidos, com posterior conclusão (Capítulo 6) e recomendações (Capítulo 7) para continuidade dos estudos, visando avanços na produção do biossurfactante usando o Rhodococcus erythropolis. 


\section{2 \\ Objetivos e relevância do trabalho}

2.1.

Objetivo geral

- Estudar a flotação do sistema hematita-quartzo utilizando o biossurfactante solúvel produzido por Rhodococcus erythropolis como reagente coletor.

\section{2.}

\section{Objetivos específicos}

- Extrair o biossurfactante solúvel produzido por Rhodococcus erythropolis.

- Quantificar as proteínas, carboidratos e lipídeos presentes no biossurfactante solúvel.

- Determinar a CMC (concentração micelar critica) do biossurfactante por meio das medidas da tensão superficial.

- Avaliar o comportamento eletroforético dos minerais, antes e após interação com o biossurfactante.

- Avaliar a hidrofobicidade dos minerais, antes e após da interação com o biossurfactante.

- Caracterizar por espectroscopia FTIR o biossurfactante e minerais, antes e após sua interação.

- Estudar a adsorção do biossurfactante na superfície dos minerais.

- Avaliar o efeito do $\mathrm{pH}$, concentração do biossurfactante e tempo na microflotação dos minerais.

- Analisar estatisticamente os dados de flotabilidade para obter a função polinomial representativa da microflotação.

- Determinar o modelo cinético com melhor ajuste aos dados experimentais de microflotação. 


\section{3. Relevância do trabalho}

O sistema de flotação hematita-quartzo foi escolhido por ser pratica de separação industrial bem estabelecida, como também pelo fato do Brasil ocupar uma posição mundial de destaque na produção e exportação de minério de ferro, e pela importância do ferro no contexto econômico nacional e internacional, devido ao seu baixo preço e aplicabilidade.

Por outo lado, a crescente demanda mundial por matérias-primas minerais vem incentivando a exploração de jazidas de baixo teor, além do tratamento e recuperação de resíduos oriundos da atividade mineral. Assim, a pesquisa de novos reagentes que apresentem maior seletividade e não sejam agressivos ao meio ambiente tem-se intensificado, dentro deles os biorreagentes. Esses biorreagentes obtidos a partir de bactérias, leveduras e fungos filamentosos, têm a capacidade de produzir biomoléculas com propriedades biossurfactantes, semelhantes aos reagentes químicos convencionais. Portanto, com o objetivo fundamental de substituir total ou parcialmente os surfactantes sintéticos, o uso de biossurfactantes como reagentes representa uma alternativa promissora aos surfatantes sintéticos utilizados na indústria mineral porque podem apresentar baixa toxicidade e natureza biodegradável.

Outra grande vantagem dos biossurfactantes, além de produzirem baixos impactos ambientais, quando comparados com os reagentes convencionais, é a possibilidade de produção utilizando substratos renováveis, o que pode ser expresso, numa consequente redução dos custos do processo. Por outra parte, além de que podem apresentar baixa toxicidade e alta biodegradabilidade, estas biomoléculas são responsáveis pela adesão e flotabilidade seletiva dos minerais e possuem diversas funções, tais como diferenças significativas quanto aos grupos hidrofóbicos e hidrofílicos, alta diversidade química, características multifuncionais, e grande estabilidade em condições extremas do $\mathrm{pH}$, temperatura e salinidade. 


\section{3 Revisão bibliográfica}

\section{1 .}

Minerais em estudo: Hematita e quartzo

A hematita é o mais abundante e importante mineral para as indústrias de ferro e aço (Sarvamangala et al., 2012). As impurezas (ganga) como o quartzo e alumino-silicatos (argilas) presente em minérios de ferro portadores de hematita são removidos por meio da flotação, utilizando reagentes químicos coletores (Sabari \& Natarajan, 2010).

Os tipos de minerais primários industriais que contêm ferro incluem óxidos e hidróxidos e, em menor grau, carbonatos (Filippov et al., 2014). No Brasil, a grande maioria dos minérios de ferro é essencialmente hematita, geralmente envolvendo outros minerais como magnetita, goethita e minerais de ganga, principalmente quartzo (Iglesias, 2012).

Já o quartzo é o segundo mineral mais abundante na crosta continental da terra. Existem muitas variedades de quartzo, que ocorre em quase todos os tipos de rochas ígneas, metamórficas e sedimentares. Por isso, ele é encontrado como uma impureza principal em todos os tipos de depósitos de minério valiosos (Singh et al., 2012) e é removido para se obter um concentrado adequado para a extração econômica dos metais valiosos (Sahoo et al., 2016b).

No minério de ferro, onde o quartzo é a principal impureza, a flotação reversa é preferida para a concentração dos minerais de ferro. Nesse processo, o coletor desempenha um papel importante no enriquecimento da qualidade das espécies minerais desejadas (Sahoo et al., 2016b). 


\section{2.}

\section{Flotação mineral}

\subsection{1.}

\section{Flotação em espuma}

A flotação em espuma, ou simplesmente flotação, é um processo físicoquímico que permite a separação das partículas minerais de interesse da ganga para obtenção final de um concentrado com um teor elevado do mineral de interesse. A separação das partículas minerais de interesse é realizada em suspensões aquosas de minerais moídos (polpa) e ocorre pelo borbulhamento de ar forçado, baseando-se nas propriedades hidrofílicas e hidrofóbicas dos minerais (Aghazadeh et al., 2015; Ali et al., 2013; Jamett et al., 2015; Marabini et al., 2007).

A Figura 1 ilustra o princípio de flotação verdadeira em uma célula de flotação mecânica. $\mathrm{O}$ agitador proporciona turbulência suficiente na fase da polpa para promover a colisão de partículas e bolhas, o que resulta na ligação de partículas hidrofóbicas às bolhas (formando agregados de partículas-bolhas) e o seu transporte para a fase de espuma para recuperação (Wills \& Finch, 2015).

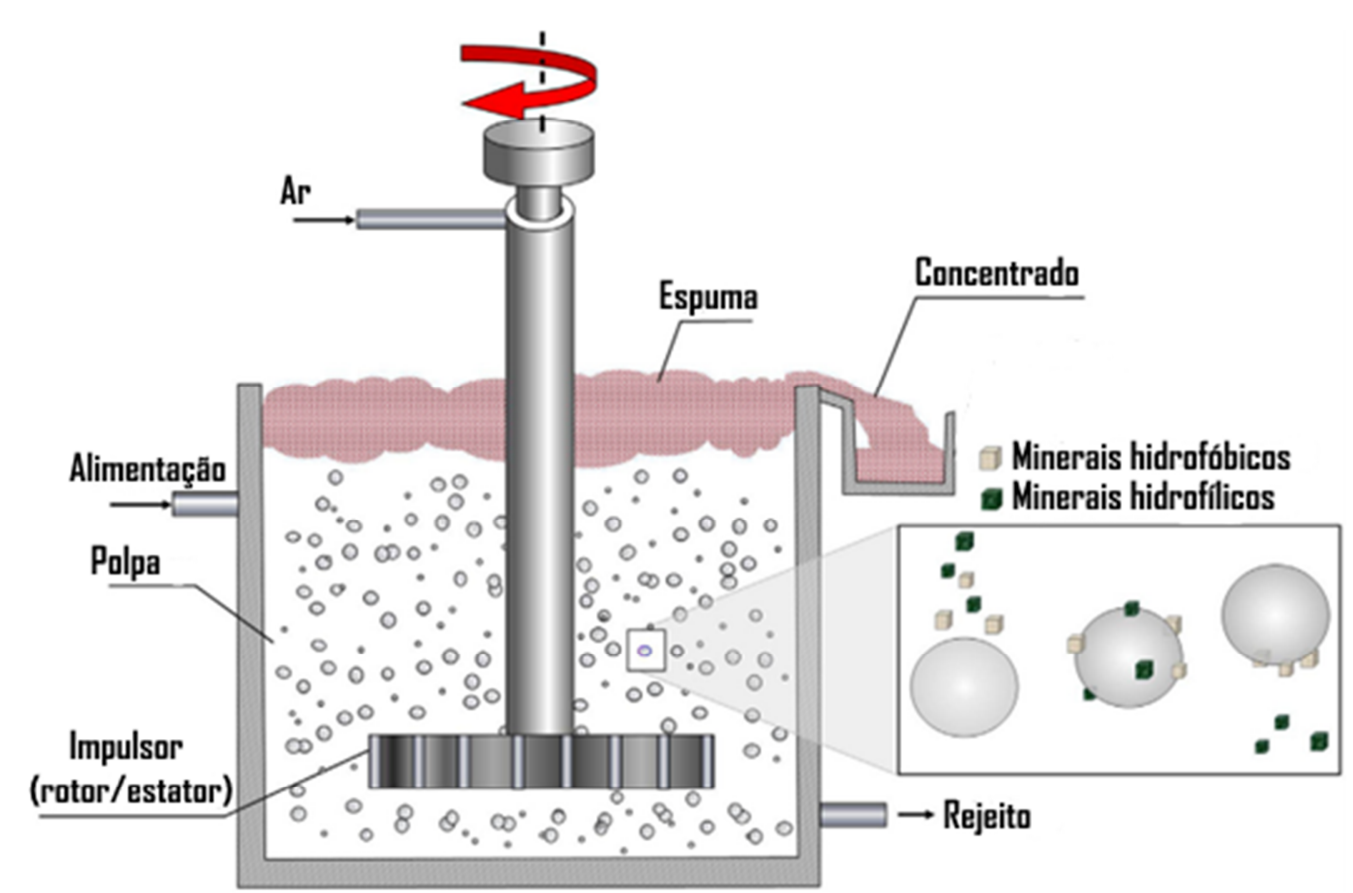

Figura 1. Princípio de flotação em espuma (Adaptado de Wills \& Finch, 2015). 
O processo de recuperação de partículas por flotação em espuma compreende três mecanismos (Wills \& Finch, 2015):

1. Colisão e adesão seletiva (attachment) de partículas com as bolhas de ar, conhecido por true flotation (flotação verdadeira);

2. Arraste hidrodinâmico (entrainment) de partículas à zona de espuma;

3. Aprisionamento físico (entrapment) de partículas entre os agregados bolha-partícula.

$\mathrm{Na}$ Figura 2 é mostrada uma representação esquemática dos três mecanismos básicos que ocorre no processo de recuperação de partículas por flotação (Santos, 2014).

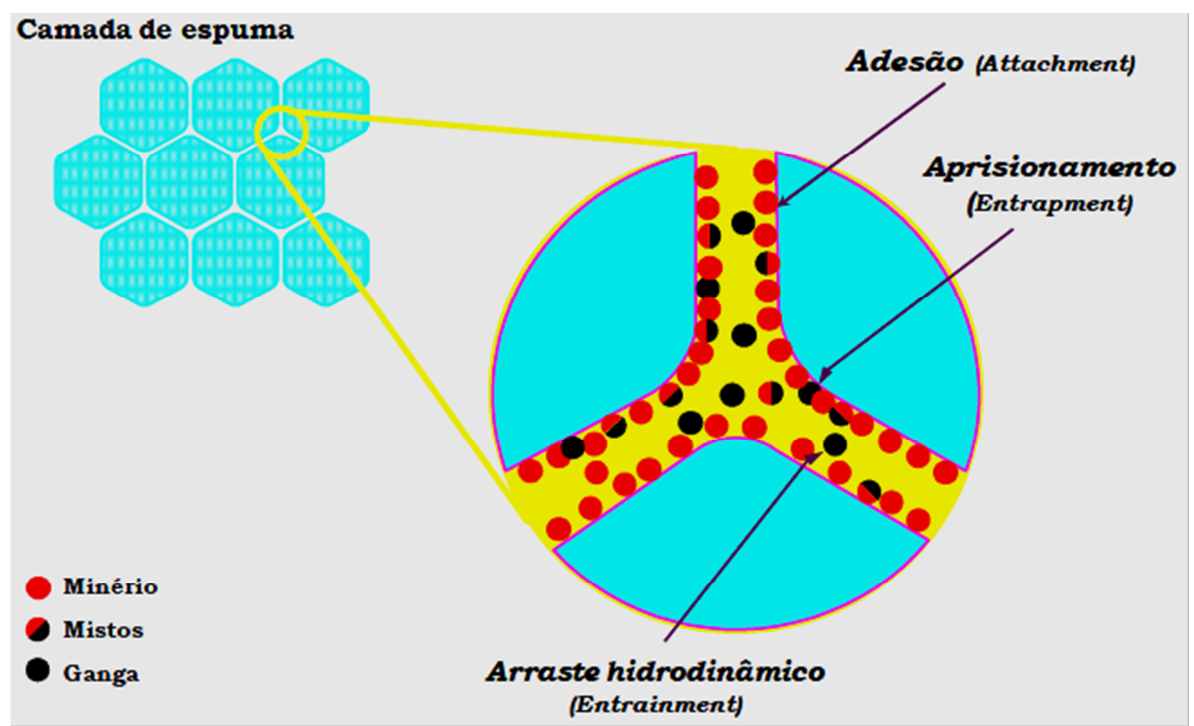

Figura 2. Mecanismos de recuperação (Santos, 2014).

No processo de flotação, os reagentes de flotação são os agentes mais importantes (Bulatovic, 2007) e sua classificação moderna é baseada em sua função específica no processo de flotação, sendo divididos em grupos de: coletores, espumantes e modificadores que podem ser depressores, ativadores, reguladores de $\mathrm{pH}$ e agentes dispersantes (Nagaraj, 2005). A função principal destes grupos de reagentes de flotação é descrita a seguir (Bulatovic, 2007):

- Coletores, cuja função principal é proporcionar propriedades hidrofóbicas às superfícies dos minerais; 
- Espumantes, que permitem a formação de uma espuma estável e o tamanho das bolhas apropriado para levar os minerais ao concentrado;

- Modificadores (que podem ser depressores, ativadores e reguladores de $\mathrm{pH}$, etc), que servem para adequar a ação efetiva do coletor e aumentar sua seletividade.

\subsection{2.}

\section{Flotação de minério de ferro}

A intensa pesquisa sobre flotação de minério de ferro começou nos Estados Unidos da América no ano 1930, desenvolvendo-se uma variedade de rotas de flotação para remover sílica a partir de minerais de ferro. As rotas de flotação de minério de ferro podem ser classificadas em cinco grupos principais: flotação catiônica de óxido de ferro, flotação catiônica de quartzo, flotação aniônica de óxido de ferro, flotação aniônica de quartzo, e combinação entre os métodos (Ma, 2012).

Atualmente, a rota estabelecida industrialmente e mais utilizada no mundo é a flotação catiônica reversa de minério de ferro. Neste processo, a sílica sob a forma de quartzo é flotado por coletores catiônicos tais como cloreto de dodecilamina, brometo de cetil trimetil amônio, éter aminas, éter monoaminas, diaminas (Sahoo et al., 2016a) e o minério de ferro predominantemente sob a forma de hematita, permanece na polpa auxiliado pelo depressor amido de milho (Ma, 2012). Este processo de flotação também pode ser aplicado para reduzir o conteúdo de sílica em concentrados de magnetita que são obtidos através da separação magnética em meio úmido (Filippov et al., 2014).

Já a flotação aniônica direta, que utiliza reagentes coletores de ácidos graxos tais como o ácido oleico ou seu sal de sódio (Sahoo et al., 2016a) é, geralmente, utilizada para minérios de ferro que possuem baixo teor ou para rejeitos que foram descartados em barragens (Araujo et al., 2005). 


\section{3. \\ Bioflotação mineral}

\subsection{1.}

\section{Aspectos gerais}

A bioflotação é a separação seletiva de um constituinte mineral de interesse de um minério mediante interação com microrganismos, que atuam como reagentes coletores ou modificadores que viabilizam a separação do constituinte mineral (Botero, 2007). Este processo de separação seletiva é baseado nos mesmos princípios e fundamentos da flotação convencional.

Entretanto, o processo de alteração das propriedades da superfície mineral pela interação de microrganismos pode ocorrer por três mecanismos diferentes (Dwyer et al., 2012):

a) Por meio de adesão da célula na superfície mineral.

b) Os microrganismos podem catalisar reações de oxidação ou de redução que modificam a superfície mineral.

c) As proteínas extracelulares e polissacarídeos produzidos pelo microrganismo podem interagir com a superfície mineral.

Durante a bioflotação, os biorreagentes modificam a superficie hidrofílica do mineral tornando-a hidrofóbica e dessa forma, facilita a separação do mineral de interesse (Botero et al., 2008; Farahat et al., 2008; Sharma, 2001; Sharma et al., 2001), apresentando-se como um processo promissor e muito atraente por se tratar de uma tecnologia ecologicamente aceitável (Calfa \& Torem, 2007; Farahat et al., 2009; Merma et al., 2013).

\subsection{2.}

\section{Características das bactérias na bioflotação mineral}

As bactérias são organismos unicelulares, procariotos, que podem ser encontrados na forma isolada ou em colônias. São microrganismos constituídos por uma célula, sem núcleo celular e com tamanhos que variam de 1 a $10 \mu \mathrm{m}$. A maioria das bactérias podem ser descritas como Gram-negativas ou Grampositivas, dependendo da composição da superfície celular e estrutura (Dwyer et al., 2012). Na Figura 3 mostra-se a parede celular quanto das bactérias Gramnegativas como das bactérias Gram-positivas. 
As bactérias Gram-negativas são células procarióticas que contém uma membrana externa e peptideoglicano em suas paredes celulares e, coram-se em rosa na coloração de Gram. Enquanto as bactérias Gram-positivas constituem um grupo grande e diverso que são uma importante linhagem filogenética de células procarióticas que contém principalmente peptideoglicano em suas paredes celulares e, coram-se em roxo na coloração de Gram (Madigan et al., 2010).

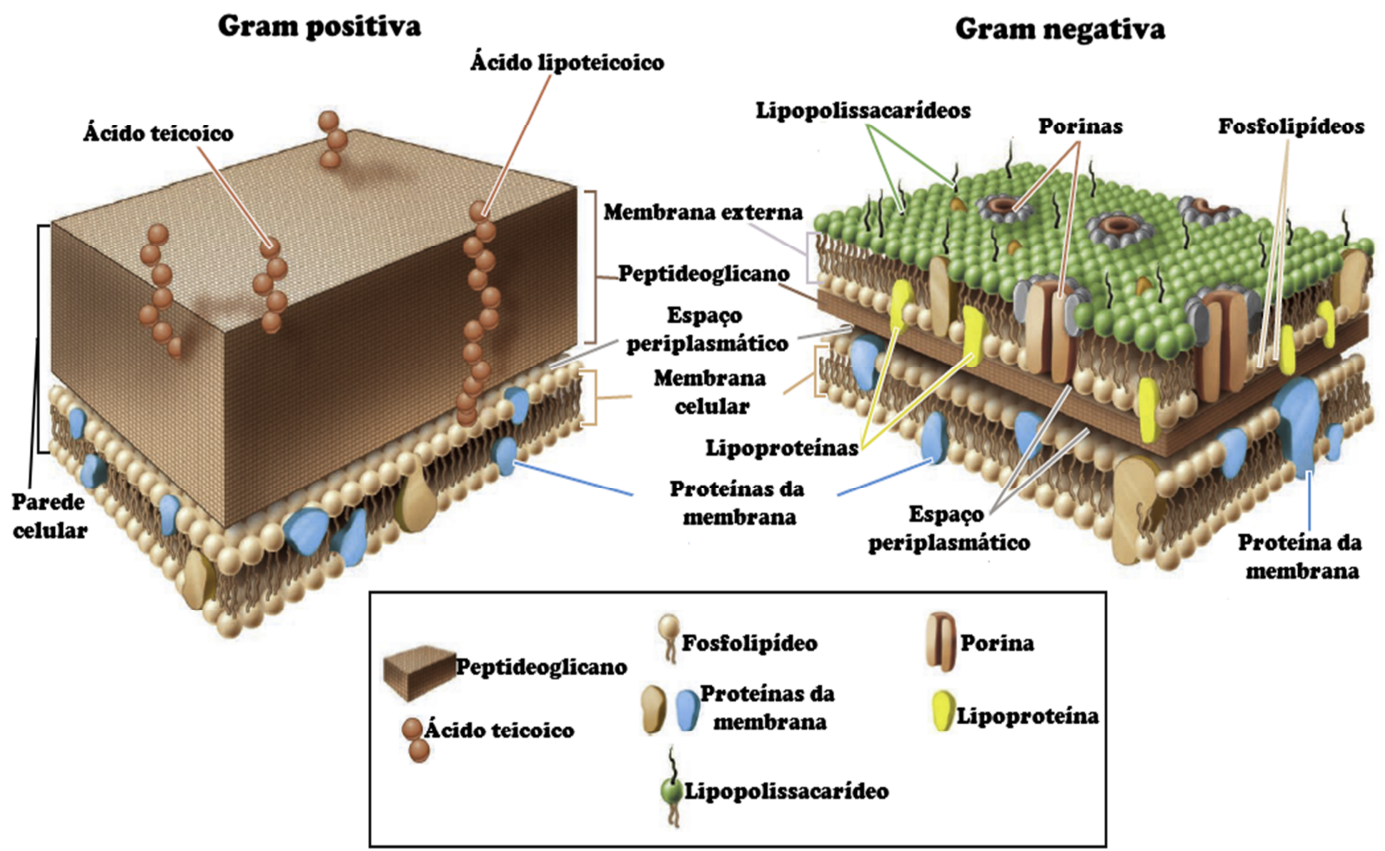

Figura 3. Parede celular da bactéria Gram positiva e bactéria Gram negativa (Adaptado de Talaro \& Chess, 2017).

\subsection{3.}

\section{Composição superficial dos microrganismos}

A parede celular é composta principalmente de polímeros como peptidoglicano, além de substâncias poliméricas extracelulares (EPS), fosfoglicerídeos, fosfolipídios, aminoácidos, proteínas, lipídeos, polissacarídeos e ácidos orgânicos, como o ácido micólico (Botero et al., 2007).

Dentre os diversos compostos, destacam-se alguns grupos funcionais, tais como carboxila (-COOH), amina (-NH2), hidroxila $(-\mathrm{OH})$ e fosfato (-PO4-) que dão origem à carga na superfície bacteriana através da sua ionização (Botero et al., 2007; Poortinga et al., 2002; Sharma \& Hanumantha, 2003). Algumas das 
possíveis reações químicas de carregamento da superfície bacteriana são dadas na Tabela 1.

Tabela 1. Grupos ionizáveis encontrados na superfície bacteriana e suas constantes de dissociação (POORTINGA et al., 2002).

\begin{tabular}{|c|c|c|}
\hline Reação & Origem & pKa \\
\hline \multirow{2}{*}{$-\mathrm{COOH} \leftrightarrow-\mathrm{COO}^{-}+\mathrm{H}^{+}$} & Polissacarídeos & 2,8 \\
\cline { 2 - 3 } & Proteína, peptideoglicano & Entre 4,0 e 5,0 \\
\hline$-\mathrm{NH}_{3}{ }^{+} \leftrightarrow-\mathrm{NH}_{2}+\mathrm{H}^{+}$ & Proteína, peptideoglicano & Entre 9,0 e 9,8 \\
\hline$-\mathrm{HPO}_{4}{ }^{-} \leftrightarrow \mathrm{PO}^{-}+\mathrm{H}^{+}$ & Ácidos teicóicos & 2,1 \\
\hline$-\mathrm{H}_{2} \mathrm{PO}_{4} \leftrightarrow-\mathrm{HPO}_{4}-{ }^{-}+\mathrm{H}^{+}$ & Fosfolipídeos & 2,1 \\
\hline$-\mathrm{HPO}_{4}{ }^{-} \leftrightarrow \mathrm{PO}_{4}{ }^{2-}+\mathrm{H}^{+}$ & Fosfolipídeos & 7,2 \\
\hline
\end{tabular}

Esses grupos funcionais conferem ao microrganismo características hidrofóbicas ou hidrofílicas, dependendo do gênero e da espécie. Sendo assim, diversos autores como: Deo \& Natarajan (1997); Sharma et al. (2001); Padukone \& Natarajan (2011) afirmam que a presença de polissacarídeos na superfície bacteriana oferece caráter hidrofílico às bactérias e aos minerais com quem interagem, enquanto que os compostos proteicos fornecem um caráter hidrofóbico.

\subsection{4.}

\section{Biorreagentes na flotação de minério de ferro}

O desenvolvimento de biorreagentes para a separação seletiva de minerais tem sido objeto de muitas pesquisas, onde o interesse em trabalhar com microrganismos que sejam seletivos na recuperação minerais é cada vez maior. Um passo essencial é compreender os mecanismos e consequências resultantes das interações micróbio-minerais antes de estabelecer sua utilidade no processamento mineral (Sarvamangala \& Natarajan, 2011).

A literatura recente demonstrou a possível utilização de espécies microbianas como reagentes de flotação na separação seletiva de vários sistemas minerais. Algumas dessas espécies são apresentadas na Tabela 2, principalmente as que foram utilizadas como biorreagentes na flotação de hematita e quartzo. 
Tabela 2. Bactérias usadas na flotação de hematita e de quartzo

\begin{tabular}{|c|c|c|c|}
\hline Biorreagente & Sistema & Função & Autor/ Ano \\
\hline \multirow{2}{*}{$\begin{array}{c}\text { Mycobacterium } \\
\text { phlei }\end{array}$} & Hematita & Coletor & (Dubel et al., 1992) \\
\hline & Finos de hematita & $\begin{array}{l}\text { Coletor e } \\
\text { Floculante }\end{array}$ & (Yang et al., 2007) \\
\hline $\begin{array}{c}\text { Bacillus polymyxa } \\
\text { ou Paenibacillus } \\
\text { polymyxa }\end{array}$ & $\begin{array}{c}\text { Hematita, } \\
\text { corundum, calcita, } \\
\text { quartzo }\end{array}$ & $\begin{array}{c}\text { Ativador de } \\
\text { quartzo }\end{array}$ & (Deo \& Natarajan, 1997) \\
\hline $\begin{array}{l}\text { Desulfovibrio } \\
\text { desulfuricans }\end{array}$ & Hematita-quartzo & $\begin{array}{c}\text { Coletor de } \\
\text { quartzo }\end{array}$ & $\begin{array}{c}\text { (Sabari \& } \\
\text { Natarajan, 2010) }\end{array}$ \\
\hline $\begin{array}{c}\text { Rhodococcus } \\
\text { opacus }\end{array}$ & Hematita-quarzo & Coletor & (Mesquita et al., 2003) \\
\hline Rhodococcus ruber & Hematita & Coletor & (Lopez et al., 2015) \\
\hline \multirow[t]{2}{*}{$\begin{array}{l}\text { Rhodococcus } \\
\text { erythropolis }\end{array}$} & $\begin{array}{c}\text { Hematita e gangas } \\
\text { (quartzo, caulinita } \\
\text { e apatita) }\end{array}$ & Coletor & (Yang et al., 2013a) \\
\hline & Hematita & Coletor & (Olivera et al., 2017) \\
\hline
\end{tabular}

\subsection{5.}

\section{Rhodococcus erythropolis}

A Rhodococus erythropolis é uma bactéria que pertence ao gênero Rhodococcus. As bactérias deste gênero são actinobactérias aeróbias, Grampositivas, com alto conteúdo de guanina e citosina, contido em seu DNA. Estes microrganismos apresentam ciclo de vida alternante entre cocos e bastonetes, algumas vezes mostrando projeções filamentosas (Ciapina, 2008; Finnerty, 1992). São amplamente distribuídas no ambiente e habitam em uma grande variedade de fontes, como ambientes marinhos, em solos Alpinos, no Ártico, na Antártica, em águas subterrâneas, excretas de animais, intestinos de insetos e em plantas doentes (Bell et al., 1998; Carvalho \& Fonseca, 2005; Martínková et al., 2009; Whyte et al., 2002). 
As células Rhodococcus erythropolis são microrganismos não patogênicos e tem sido amplamente utilizado para a bioremediação de águas e solos contaminados por petróleo (Carvalho, 2012; Liu \& Liu, 2011). Na Figura 4, observam-se diversas células Rhodococcus erythropolis.

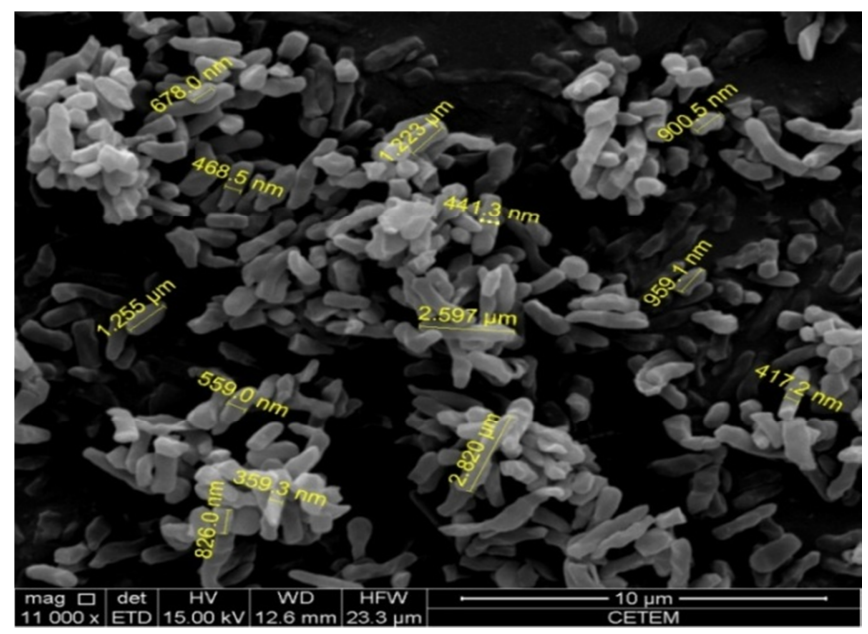

Figura 4. Células Rhodococcus erythropolis (Olivera, 2014).

Na flotação mineral, foi utilizada como coletor de hematita com a finalidade de determinar sua viabilidade na separação de minério composto por minerais de hematita, quartzo, caulinita e apatita (Yang et al., 2013a). Na Figura 5, mostra-se a eficiência da recuperação de hematita $(89,67 \%)$ em comparação com outros minerais puros.

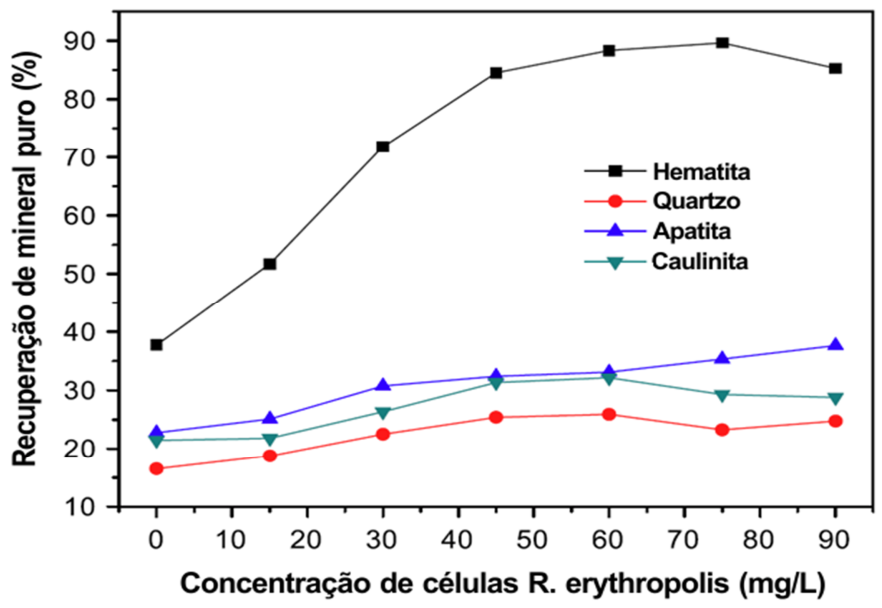

Figura 5. Efeito de Rhodococcus erythropolis na recuperação de hematita, quartzo, apatita e caulinita, pH 6 (Adaptado de Yang et al., 2013a). 
No trabalho de Olivera (2014) também foi utilizada como coletor de hematita e demonstrou-se que o Rhodococcus erythropolis tem uma aplicação viável como biorreagente. A maior flotabilidade $(83,86 \%)$ foi alcançada no $\mathrm{pH} 6$, com uma concentração de biomassa de $200 \mathrm{mg} / \mathrm{L}$, conforme é mostrado na Figura 6.

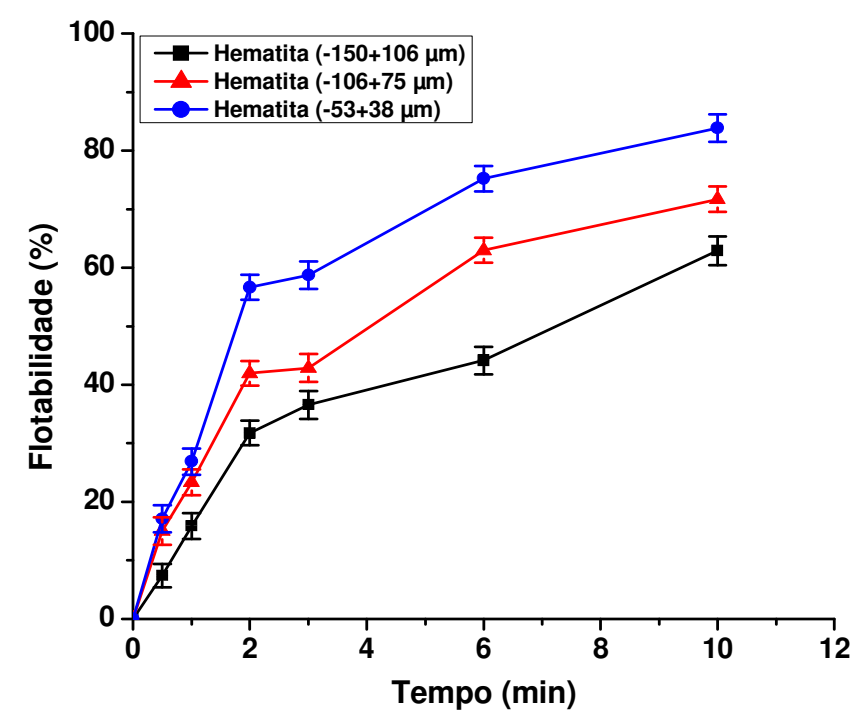

Figura 6. Flotabilidade da hematita em função do tempo: pH 6 e concentração de biomassa de 200 mg/L (Adaptado de Olivera, 2014).

\subsection{6.}

\section{Propriedades eletrocinéticas dos biorreagentes}

A adesão ou adsorção de microrganismos à superfície mineral depende das condições da solução como $\mathrm{pH}$ e força iônica, e das propriedades superficiais do mineral e do microrganismo, que incluem potencial zeta e hidrofobicidade (Hirajima et al., 2012).

Portanto, os fenômenos que ocorrem na interface sólida-líquida podem ser avaliados por meio dos efeitos eletrocinéticos das partículas em suspensão e interpretados pela teoria da dupla camada elétrica (Monte \& Peres, 2010).

No início do século XX, Gouy e Chapman propuseram que a carga superficial do mineral seria anulada por uma camada difusa de íons de carga oposta, ao contrario do modelo de camada de cargas elétricas fixas, anteriormente propostas por Helmholtz. No modelo da dupla camada difusa, os íons em solução são atraídos eletrostaticamente para a superfície do sólido, onde essa atração será 
contrabalanceada pelo movimento dos contra-íons, imprescindíveis à equalização da concentração de cargas ao longo da interface. O íons em solução com cargas iguais às das partículas são denominados co-íons enquanto aqueles com carga oposta à da partícula são denominados contra-íons. Tanto os co-íons como os contra-íons podem adsorver-se especificamente na superfície do sólido. O plano interno de Helmholtz (PIH) é aquele que passa pelos centros desses íons, especificamente adsorvidos por mecanismo químico na superfície do sólido. Já o plano externo de Helmholtz (PEH) passa pelo centro dos contra-íons, situados próximos à superfície do sólido adsorvidos pelo mecanismo físico ou eletrostático (Santos, 2014).

Posteriormente aos estudos de Gouy e Chapman, Stern propôs a possibilidade da existência de cargas alinhadas além da camada difusa. Uma das mais importantes contribuições da teoria de Stern foi considerar os efeitos de adsorção específica, isto é, os íons poderiam ser adsorvidos na superfície por forças de caráter não eletrostático. Ainda sobre o modelo de Stern, nas vizinhanças da superfície, uma primeira camada estacionária seria formada por íons adsorvidos à superfície por adsorção específica ou forças eletrostáticas, enquanto o restante dos íons de carga oposta à da superfície e necessários à neutralização, estariam espalhados por efeito da agitação térmica, decrescendo exponencialmente sua concentração, conforme a teoria de Gouy-Chapman. Assim, o modelo de Stern-Gouy-Chapman é o mais utilizado para descrever a estrutura da dupla camada elétrica em sistemas coloidais considerando a influencia dos eletrólitos na carga superficial da partícula (Santos, 2014; Monte \& Peres, 2010). A Figura 7 ilustra o modelo de Stern da dupla camada elétrica e a distribuição do potencial eletrostático. 

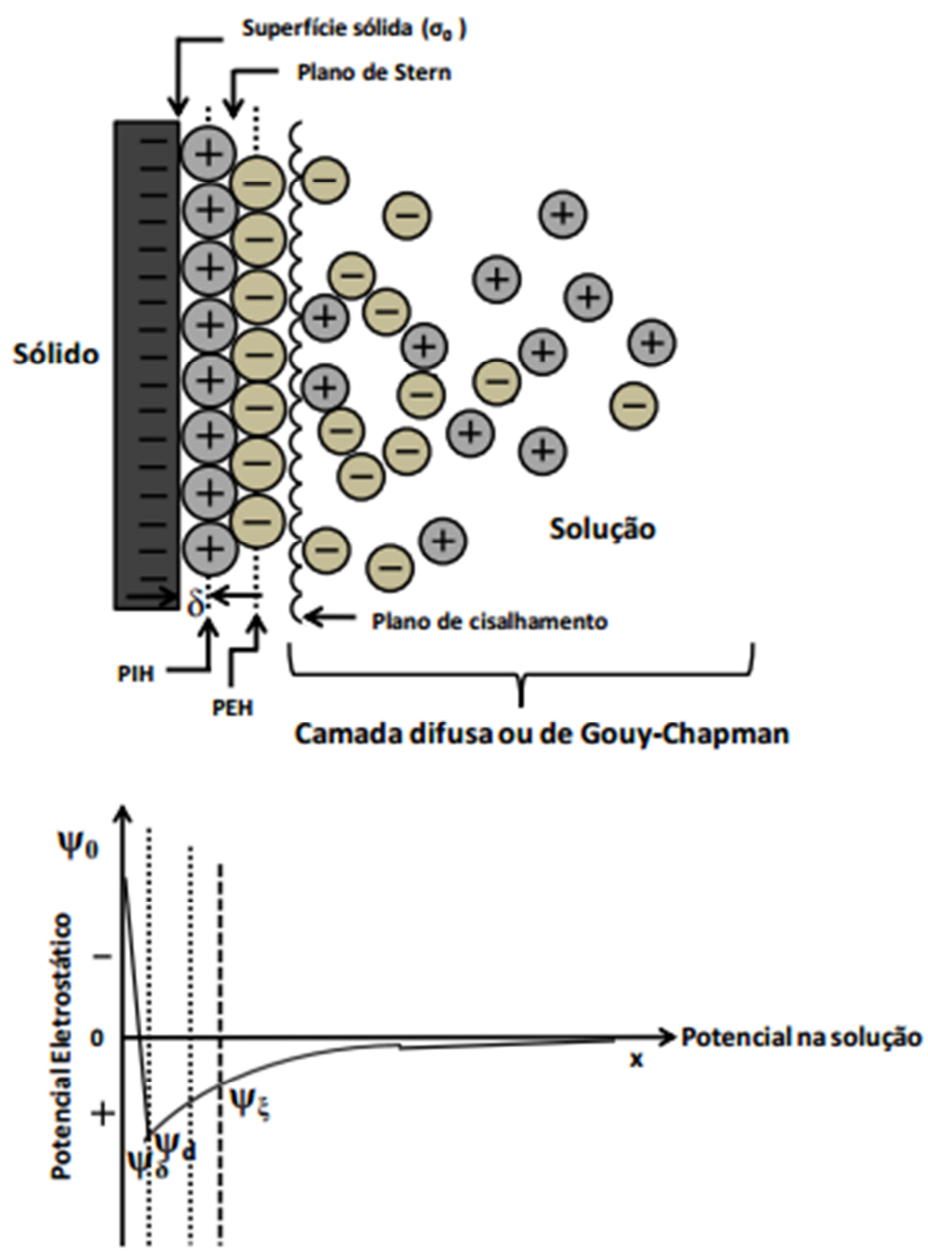

Figura 7. Estrutura da dupla camada elétrica (Santos, 2014)

O potencial eletrostático da superfície $\left(\Psi_{0}\right)$, da camada de Stern $\left(\Psi_{\delta}\right)$ e da camada difusa $\left(\Psi_{\mathrm{d}}\right)$ são hipotéticos. Na dupla camada elétrica (DCE), o único potencial que pode ser medido experimentalmente é o potencial zeta $\left(\Psi_{\xi}\right)$, isto é, o potencial medido no plano de cisalhamento entre a partícula e a solução, quando ambos estão em movimento relativo, na presença de um campo elétrico. Esse deslocamento diferencial das partes da DCE leva ao aparecimento de um potencial eletrocinético, podendo ser medido por meio dos quatros fenômenos ou efeitos eletrocinéticos: eletroforese, eletroosmose, potencial de escoamento e potencial de sedimentação (Monte \& Peres, 2010).

O potencial zeta $\left(\Psi_{\xi}\right)$ é um importante parâmetro a ser medido com auxílio da eletrocinética. As técnicas mais usadas para sua determinação são a eletroforese e o potencial de escoamento. A técnica de eletroforese consiste em medir a mobilidade eletroforética das partículas carregadas em uma suspensão 
aquosa (as partículas eletricamente carregadas, suspensas em uma polpa, movimentam-se sob a ação de um campo elétrico aplicado), enquanto, o potencial de escoamento é o campo elétrico gerado quando um líquido flui sobre uma superfície estacionária carregada eletricamente (Hunter, 1981; Monte \& Peres, 2010).

$\mathrm{Na}$ prática, efetuam-se várias medidas da mobilidade eletroforética das partículas dispersas em solução aquosa. $\mathrm{O}$ cálculo de $\Psi_{\xi}$ com base nessas medidas pode ser feito segundo a equação de Smoluchowski (Hunter, 1981):

$$
\Psi_{\xi}=12.8 \mu_{\mathrm{e}}
$$

Onde o potencial zeta $\left(\Psi_{\xi}\right)$ é expresso em $\mathrm{mV}$ e a mobilidade $\left(\mu_{\mathrm{e}}\right)$ em $\mu \mathrm{m} \mathrm{s}^{-1} /$ $\mathrm{V} \mathrm{cm}{ }^{-1}$.

Os íons determinantes do potencial são aqueles que exercem um controle significativo sobre a carga da superfície e a carga da superfície da fase dispersa. Sendo assim, o ponto isoelétrico (PIE) é definido como o logaritmo negativo da atividade dos íons para o qual a carga líquida no plano de cisalhamento é nula, e é obtido pela medida do potencial zeta na presença de um eletrólito indiferente (Monte \& Peres, 2010).

Na revisão da literatura, alguns dos valores do ponto isoelétrico encontrados para o mineral hematita estão em: pH 5,8 (Deo et al., 2001); pH 5,1 (Mesquita et al., 2003); pH 6 - 6,5 (Sarvamangala \& Natarajan, 2011); pH 5,2 (Yang et al., 2013a); pH 5,5 (Yang et al., 2013b, 2014a); pH 5,5 (Lopez et al., 2015) e pH 5,3 (Olivera et al., 2017). Já para o bactéria Rhodococcus erythropolis, segundo o trabalho de Yang et al. (2013b), sua superfície foi carregada negativamente na faixa de pH 2 a pH 10, mas no trabalho de Olivera et al. (2017) foi encontrado o valor do ponto isoelétrico ao redor do pH 2,2. Essa variação do PIE é atribuída a diversos fatores, entre eles, os mais importantes são a sua composição, origem e o método usado para determinar o potencial zeta, além do tempo de acondicionamento da amostra em solução.

A Figura 8, mostra o perfil das curvas de potencial zeta encontradas por (Olivera, 2014): hematita, Rhodococcus erythropolis e interação. O ponto isoelétrico da hematita e Rhodococcus erythropolis foram encontrados em $\mathrm{pH}$ 5,3 e pH 2,2 respectivamente. Após interação, o ponto isoelétrico da hematita diminuiu de $\mathrm{pH}$ 5,3 para $\mathrm{pH}$ 2,1, adotando um comportamento muito próximo ao 
perfil da curva de potencial zeta da bactéria. Esta modificação do perfil da curva de potencial zeta pode ser relacionada com a aderência das células bacterianas e/ou adsorção de qualquer produto metabólico sobre a superfície do mineral.

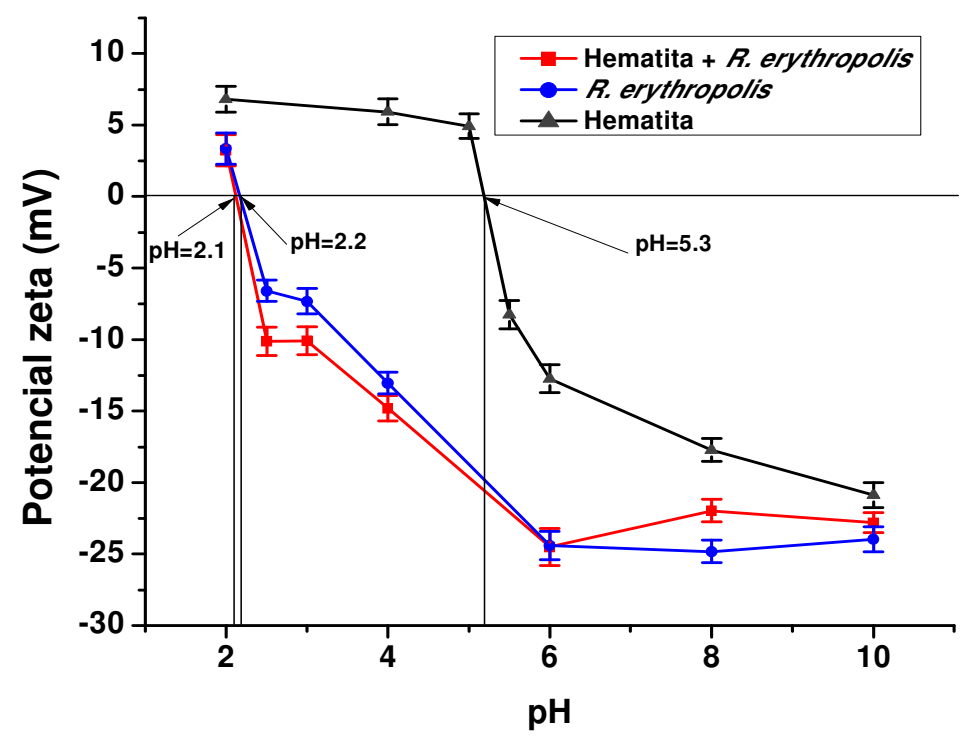

Figura 8. Perfis de potencial zeta com eletrólito indiferente: $\mathrm{NaCl} 10^{-3} \mathrm{~mol} / \mathrm{L}$ (Adaptado de Olivera, 2014).

O potencial do mineral quartzo também foi estudado por diversos pesquisadores. No trabalho de Barros et al. (2008) foi observado que o mineral quartzo não apresentou ponto isoelétrico e seu potencial eletrocinético foi negativo em toda a faixa de $\mathrm{pH}$ estudada $(\mathrm{pH} 8,5-\mathrm{pH} 10,5)$. Enquanto, no trabalho de Yang et al. (2013b), o ponto isoelétrico do quartzo foi em torno do $\mathrm{pH}$ 3,0 e para os outros minerais como apatita, caulinita e hematita foram em torno do pH 3,0, 3,3 e 5,2, respectivamente, conforme é mostrado na Figura 9.

$\mathrm{Na}$ literatura recente, Zhou et al. (2015) mediram o potencial zeta de quartzo, apatita e dolomita. $\mathrm{O}$ potencial dos minerais diminuiu conforme o $\mathrm{pH}$ da solução aumentou, sendo o potencial zeta do quartzo mais negativo e não apresentou ponto isoelétrico. Enquanto o PIE da apatita e dolomita foi encontrado em torno do $\mathrm{pH} 4,2$ e 6,2 , respectivamente. 


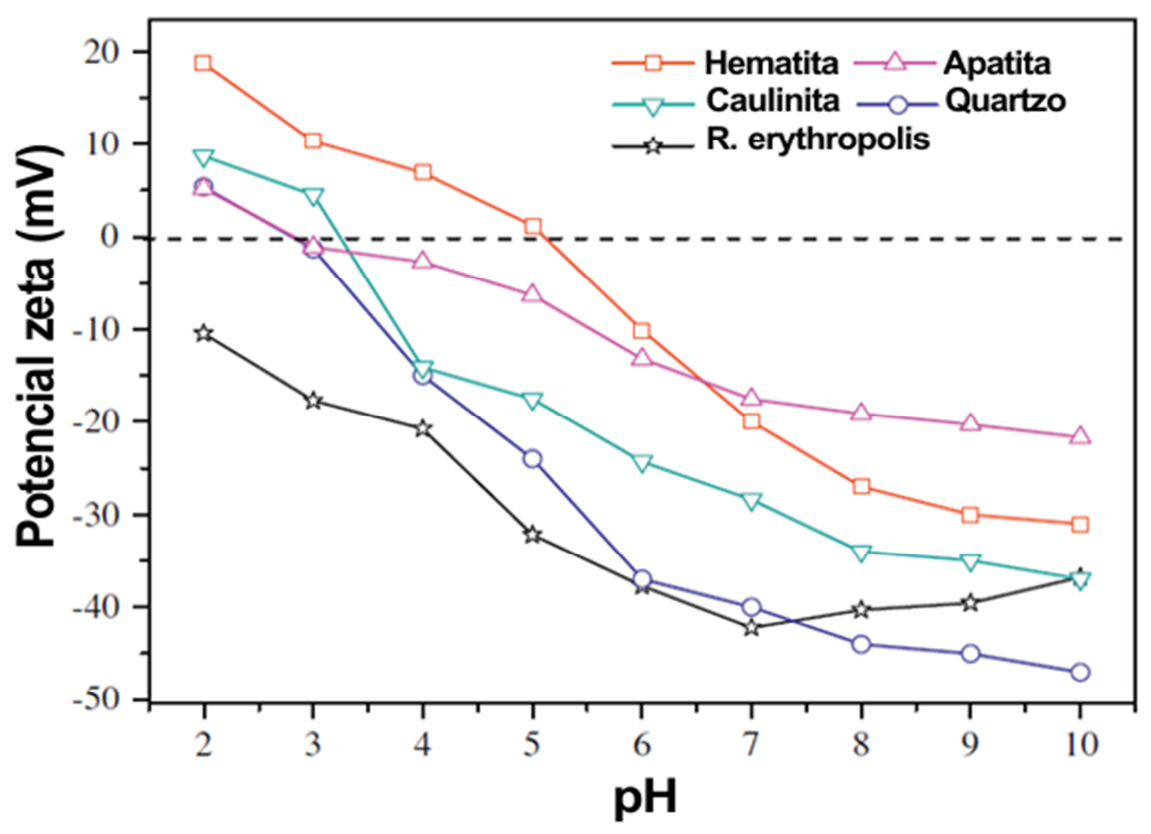

Figura 9. Curvas de potencial zeta para o Rhodococcus erythropolis, hematita, quartzo, apatita e caulinita (Adaptado de Yang et al., 2013a).

\subsection{7. Adsorção dos biorreagentes}

Adsorção é um fenômeno físico-químico onde o componente em uma fase gasosa ou líquida é transferido para a superfície de uma fase sólida. Os componentes que se unem à superfície são chamados de adsorvatos, enquanto que a fase sólida que retém o adsorvato é chamada adsorvente (Oliveira, 2010). A atração pode ser muitas vezes baseada em cargas eletrostáticas. A adsorção negativa é a adsorção de espécies positivas por locais de adsorção negativa e viceversa para a adsorção positiva. Embora o termo adsorção implique um fenômeno de superfície, o sequestro real pode ter lugar com base em fenômenos físicos (adsorção física) ou através de uma variedade de meios de ligação química (quimissorção). A adsorção física é não específica, e as forças que atraem as moléculas para a superfície sólida são relativamente fracas. Enquanto a quimissorção é específica e envolve forças muito mais fortes do que na adsorção física (Naja \& Volesky, 2011). As diferenças entre a quimissorção e a adsorção física são resumidas na Tabela 3. 
Tabela 3. Fundamentos dos métodos de sorção (Naja \& Volesky, 2011)

\begin{tabular}{|l|l|l|}
\hline Parâmetro & Adsorção Física & Quimissorção \\
\hline Faixa de & Mais baixo & Mais alto \\
temperatura & Mais baixo & Mais alto \\
Calor de adsorção & Condensação & Reação \\
Ordem de H & Rápida & Não ativada \\
Taxa & Baixa & Baixa \\
Energia de ativação & Possível & Monocamada \\
Cobertura & multicamada & Frequentemente \\
Reversibilidade & Alta & irreversível \\
\hline
\end{tabular}

Além de ser complexo, o processo de adsorção depende de várias características da solução aquosa tais como $\mathrm{pH}$, salinidade, temperatura, força iônica, íons bivalentes e adicionalmente o tipo, concentração e composição dos surfactantes envolvidos (Azam et al., 2013; Mende et al., 2016; Naja \& Volesky, 2011).

\subsection{8.}

\section{Molhabilidade e ângulo de contato}

A flotação de partículas minerais de interesse é vinculada à molhabilidade com a água, de modo que se explora a termodinâmica de molhabilidade entre uma gota do líquido e a superfície no qual ela repousa. O parâmetro que define a molhabilidade é o ângulo de contato, que é o ângulo entre um plano tangente a uma gota do líquido e um plano contendo a superfície onde o líquido se encontra depositado, conforme esquematizado na Figura 10. Logo, a molhabilidade de uma superfície depende do equilíbrio termodinâmico entre este sistema de três interfaces: sólido, líquido e gás. Assim, o ângulo de contato representa uma medida quantitativa do processo de molhabilidade (Cunha, 2015). 


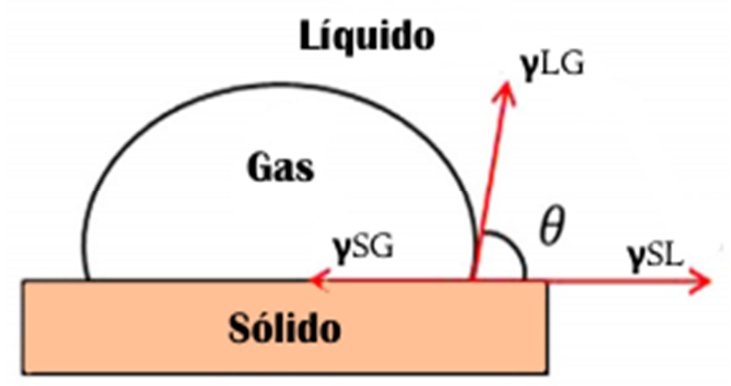

Figura 10. Representação clássica do ângulo de contato e forças de tensão superficial (Adaptado de Wills \& Finch, 2015).

A equação de Young estabelece a condição termodinâmica de equilíbrio entre as interfaces envolvidas, onde o ângulo de contato $\theta$ depende da tensão superficial ou energia livre superficial, $\gamma$, das três interfaces:

$$
\gamma_{S G}-\gamma_{S L}=\gamma_{L G} \cdot \cos \theta
$$

Onde:

$\gamma_{\mathrm{SG}}$ : Tensão superficial na interface sólido-gás

$\gamma_{\mathrm{SL}}$ : Tensão superficial na interface sólido-líquido

$\gamma_{\text {LG }}$ : Tensão superficial na interface líquido-gás

A equação de Young é válida para um sistema ideal, onde todos os efeitos gravitacionais estão ausentes e as três fases em equilíbrio.

A variação da energia livre de adesão entre partículas hidrofóbicas e bolhas de ar é obtida pela equação de Dupré.

$$
\Delta G=\gamma_{S G}-\left(\gamma_{S L}+\gamma_{L G}\right)
$$

A equação de Dupré expressa o decréscimo máximo possível da energia livre do sistema, que resulta no contato partícula-bolha, sem levar em consideração, no entanto, o trabalho requerido para deformar a bolha antes da ligação com o sólido bem como a geometria do sistema. 
Combinando a equação de Young (2) com a forma apropriada da equação de Dupré (3), obtém-se a equação de Young-Dupré, a qual fornece o critério termodinâmico para a flotação:

$$
\Delta G=\gamma_{L G}(\cos \theta-1)
$$

Está equação é usado com frequência para analisar o processo de flotação, o que significa que a ligação partícula-bolha e a subsequente flotação são possíveis se a variação da energia livre da ligação é negativa, isto é, quanto mais negativo o valor de $\Delta G$ maior é a probabilidade da flotação da partícula. Dessa forma $\Delta G$ é negativo quando o ângulo de contato está entre $0^{\circ}$ e $180^{\circ}$, isto é, quando a superfície é hidrofóbica.

Além da condição termodinâmica, as equações de Young (2) e de YoungDupré (4) introduzem o conceito que a flotabilidade de um sólido é controlada pela energia superficial. Dessa forma, o processo de flotação pode ser visto como a arte e a ciência de converter os sólidos de energia superficial alta em sólidos de energia superficial baixa (hidrofóbicos). Assim, as moléculas do surfactante interagem com o sólido, além das interações com as outras interfaces disponíveis, causando uma diminuição da energia superficial do sólido, $\gamma_{S}$, sendo que esses valores devem ser bem menores que os obtidos na interface líquido/gás, $\gamma_{L G}$ (Monte \& Peres, 2010).

\subsection{9.}

\section{Cinética de flotação mineral}

A abordagem de engenharia é considerar a flotação como um processo de taxa por analogia com a cinética da reação química. Os reagentes em flotação são a bolha e a partícula e, o produto é o agregado bolha-partícula. Deste ponto de vista, a taxa de flotação dependerá de um número de fatores como: concentração de partículas e bolhas, frequência de colisão, eficiência da ligação da partícula após colisão e estabilidade da ligação (Wills \& Finch, 2015).

Os modelos matemáticos que descrevem a flotação em espuma como um processo de taxa são classificados em seis categorias: modelos cinéticos baseados em analogia química, modelos probabilísticos e estocásticos, modelos 
multifásicos, modelos mecanicistas, modelos cinéticos e modelos de flotação contínua (Hernáinz \& Calero, 2001).

Os modelos cinéticos que consideram o processo de flotação como uma reação entre partículas e bolhas são os mais comuns, devido à sua simplicidade e capacidade de simular razoavelmente bem a operação de flotação. Esses modelos são formulados em termos da taxa de flotação e podem ser quantificados em termos de parâmetros físicos, químicos e hidrodinâmicos do sistema de flotação (Alvarez-Silva et al., 2016).

Segundo Hernáinz et al. (2005), a avaliação das equações de taxa pode ser baseada em suposições ou em fatos estabelecidos sobre o mecanismo dos processos ou, mais comumente determinados empiricamente ou por analogia com os processos de taxa semelhante. Por analogia com a cinética química, a equação que representa a cinética de flotação pode ser expressa, assim:

$$
\frac{d C}{d t}=-K \cdot C^{n}
$$

Onde, C: concentração de sólidos, t: tempo de flotação, n: ordem da reação, e k: constante de taxa de flotação, que pode ser definida como uma medida da eficiência de flotação.

Existem diferentes métodos para determinar a cinética da bioflotação, sendo os modelos mais comumente usados: modelo de primeira ordem, modelo de segunda ordem e modelo de ordem fracionária; conforme é mostrado na Tabela 4.

Tabela 4. Modelos cinéticos de flotação mineral (Olivera et al., 2017).

\begin{tabular}{|c|c|c|}
\hline Ordem & \multicolumn{2}{|c|}{ Equação } \\
\hline $\mathrm{n}=1$ & $\ln \left(\frac{\mathrm{m}_{0}}{\mathrm{~m}}\right)=\mathrm{K}_{1} \cdot \mathrm{t}$ & $\ln \left[\frac{1}{(1-R)}\right]=K_{1} \cdot t$ \\
\hline $\mathrm{n}=2$ & $\frac{1}{m_{f}}=\frac{1}{m_{0}}+K_{2} \cdot t$ & $\frac{\mathrm{R}}{(1-\mathrm{R})}=\mathrm{m}_{0} \mathrm{~K}_{2} \cdot \mathrm{t}$ \\
\hline Fracionária & $\ln \left[\overline{\left(R_{0}\right.}\right.$ & $\overline{R)}]=\mathrm{K} \cdot \mathrm{t}$ \\
\hline
\end{tabular}




\section{Onde:}

$\mathbf{m}_{\mathbf{0}}$ : Massa inicial, $\mathbf{m}_{\mathbf{f}}$ : Massa final, $\mathbf{k}$ : Constante de taxa do modelo, $\mathbf{t}$ : tempo, $\mathbf{R}$ : Percentagem de recuperação do mineral e $\mathbf{R}_{\infty}$ : Percentagem de máxima recuperação do mineral no tempo infinito.

Do ponto de vista prático, a hidrofobicidade e a mineralização da bolha de ar são provavelmente os dois fatores mais importantes na flotação mineral e ambos governam a seletividade e a cinética da flotação, respectivamente. Dessa forma a hidrofobicidade da partícula é o primeiro pré-requisito importante, enquanto o mecanismo de mineralização da bolha está associado com um grande número de fatores físicos, químicos e mecânicos (Bulatovic, 2007).

\section{4 .}

\section{Surfactantes e Biossurfactantes}

\subsection{1.}

\section{Surfactantes}

Os surfactantes são moléculas anfipáticas constituídas de uma porção hidrofóbica e uma porção hidrofílica. A porção apolar é frequentemente uma cadeia hidrocarbonada enquanto a porção polar pode ser iônica (aniônica ou catiônica), não-iônica ou anfotérica (Nitschke \& Pastore, 2002).

O termo anfifílico é derivado do grego "amphi", que significa "ambos" ou "nos dois lados", refere-se ao fato de que todas as moléculas surfactantes consistem de pelo menos duas partes, uma das quais é solúvel em um fluido específico, por exemplo, água (a parte hidrofílica) e a outra insolúvel em água (a parte hidrofóbica) (Tadros, 2014).

Do ponto de vista comercial, os surfactantes ou agentes tensoativos são frequentemente classificados de acordo com sua aplicação. No entanto, isso não é muito útil porque muitos surfactantes têm vários usos, o que provoca confusão. A classificação mais aceitável e cientificamente válida de surfactantes é baseada na sua dissociação em água. Dessa forma, três classes principais podem ser distinguidas: aniônicos, não iônicos e catiônicos (Salager, 2002). A Figura 11, mostra alguns exemplos típicos de cada classe. 
Os surfactantes aniônicos são dissociados em água em um ânion anfifílico e um cátion, o qual é em geral um metal alcalino $\left(\mathrm{Na}^{+}, \mathrm{K}^{+}\right)$ou uma amônia quaternária. Esses surfactantes são mais utilizados e entre eles incluem-se sulfonatos de alquilbenzeno (detergentes), sais de ácidos graxos (sabões), lauril sulfato (agente espumante), dialquil-sulfossuccinato (agente molhante) e lignossulfonatos (dispersantes) (Salager, 2002).

Os surfactantes não iônicos são aqueles que em solução aquosa não se ionizam porque possuem grupos hidrofílicos como álcool, fenol, éter, éster, ou amida. Uma grande parte destes agentes tensoativos pode tornar-se relativamente hidrofílico devido à presença de uma cadeia de poliéster (óxido de etileno). O grupo hidrofóbico é geralmente um radical alquilo ou alquilo benzeno e, por vezes, uma estrutura de origem natural como um ácido graxo, especialmente quando é necessária uma baixa toxicidade (Salager, 2002).

Os surfactantes catiônicos são dissociados em solução aquosa num cátion anfifílico e um ânion, na maioria das vezes do tipo halogênio. A grande maioria destes agentes tensoativos corresponde os compostos de nitrogênio, tais como os sais de aminas graxas ou de amônia quaternária (Salager, 2002).

Quando uma única molécula de surfactante exibe dissociações tanto aniônico como catiônico é chamado anfótero ou zwitteriônico. Este é o caso de produtos sintéticos, tais como betaínas ou sulfobetaínas e substâncias naturais, tais como aminoácidos e fosfolipídios (Salager, 2002). 
<smiles></smiles>

Dodecil-benzenossulfonato de sódio<smiles>CCCCCCCCCP(=O)(OC)OC</smiles>

Dimetil éter do ácido tetradecil fosfônico

$$
\begin{gathered}
\mathrm{C}_{11} \mathrm{H}_{29}-\mathrm{C}-\mathrm{N}-\mathrm{CH}_{2}-\mathrm{CH}_{2} \\
\text { O I }
\end{gathered}
$$

Lauril monoetanol amida<smiles>CC(=O)OOCC(C)O</smiles>

Gliceral diéster (diglicerídeo)<smiles>CCNCCC(=O)O</smiles><smiles>CC(C)C1=CC2=CCC3C(C)(C(=O)O)CCCC3(C)C2CC1</smiles><smiles>CCCCCCCCOc1ccc([Hg]C)cc1</smiles>

Dctilfenol polietoxilado<smiles>[R]OC1OC(CO)C(O)C(O)C1OC([R])=O</smiles>

Monoéster de sorbitana<smiles>CCCCCCCCC</smiles>

Cloreto de n-dadecil piridina

Figura 11. Fórmulas desenvolvidas de alguns surfactantes comuns ( Adaptado de Salager, 2002).

Os surfactantes ou agentes tensoativos de superfície, em geral, podem ser classificados em dois grupos principais: surfactantes sintéticos e biossurfactantes. Os surfactantes sintéticos são produzidos através de reações químicas orgânicas e os biossurfactantes são produzidos por processos biológicos, sendo excretados extracelularmente por microrganismos tais como bactérias, fungos e leveduras (Pornsunthorntawee et al., 2009). 


\subsection{2. \\ Biossurfactantes}

Os biossurfactantes são compostos produzidos por microrganismos extracelularmente ou como parte das membranas celulares, sendo que a maior parte deles usados comercialmente é produzida por bactérias (Decesaro et al., 2015). Esses biossurfactantes apresentam as mesmas características dos surfactantes químicos, reduzem a tensão superficial, a concentração micelar critica e a tensão interfacial. Possuem uma estrutura comum, onde a molécula é constituída por duas porções, uma hidrofílica que pode ser composta de aminoácidos ou peptídeos, mono, di ou polissacarídeos, e a outra hidrofóbica constituída de uma cadeia hidrocarbônica de um ou mais ácidos graxos, saturados ou insaturados (Almeida, 2009).

Os biossurfactantes podem estar envolvidos na patogênese devido à sua atividade superficial; no entanto, por razões de segurança e regulamentares, as estirpes produtoras devem ser não patogênicas. Podemos mencionar como exemplo o biossurfactante de tipo ramnolipídeos, este não é o caso, mas a Pseudomonas aeruginosa que é sua bactéria produtora mais comum, é um agente patogênico (Walter et al., 2010).

$\mathrm{Na}$ maioria dos casos, os biossurfactantes são compostos de baixo peso molecular, tais como lipopeptídeo, glicolipídeo, e fosfolipídeo ou de alto peso molecular como lipoproteínas, lipopolissacarídeos, proteínas, polissacáridos e biopolímeros complexos (Liu et al., 2016).

Uma das estratégias mais importantes para aumentar a produção de biossurfactante por microrganismos é a modificação do meio de cultura, no qual a mistura de compostos de hidrocarbonetos, fontes de carbono (açúcares) e as fontes de nitrogênio são otimizadas para aumentar a síntese do biossurfactante (Fooladi et al., 2016).

\subsection{3.}

\section{Classificação dos biossurfactantes}

Os biossurfactantes possuem propriedades físico-químicas similares a dos surfactantes sintéticos e se classificam segundo sua composição química, com base no seu grupo funcional e quanto à origem microbiana, sendo que as 
principais classes de biossurfactantes incluem: glicolipídeos, lipopeptídeos e lipoproteínas, fosfolipídios e ácidos graxos, surfactantes poliméricos e surfactantes particulados (Decesaro et al., 2015; Pacwa-Płociniczak et al., 2011).

\subsubsection{1.}

\section{Glicolipídeos}

Os glicolipídeos são os biossurfactantes mais comumente descritos e são formados por carboidratos (parte hidrofílica) ligados com ácidos alifáticos de cadeia longa ou ácidos hidroxi-alifático (porção hidrofóbica). A ligação é por meio de éter ou de um grupo éster. Os glicolipídeos mais bem estudados são os ramnolipídeos, soforolipídeos e trealolipídeos (Dhanarajan \& Sen, 2014).

Ramnolipídeos são biossurfactantes extracelulares produzidos principalmente pela bactéria Pseudomonas aeruginosa e são compostos de uma parte ramnose e uma parte lipídica. Esses biossurfactantes são caracterizados por terem propriedades físico-químicas únicas, como: atividade superficial, capacidade de molhar, detergência e outras qualidades anfipáticas que os tornam altamente importantes para aplicações na indústria alimentícia, cosmética, farmacêutica, química e agrícola (Moussa et al., 2017).

Os Soforolipídeos consistem de um carboidrato dimérico da soforose ligado a um hidroxi-ácido graxo de cadeia longa, e são produzidos principalmente por leveduras tais como Torulopsis bombicola, T. apicola e Wickerhamiella domericqiae. Esses biossurfactantes têm a capacidade de diminuir a tensão superficial da água de $72,8 \mathrm{mN} / \mathrm{m}$ para $40-30 \mathrm{mN} / \mathrm{m}$, com uma concentração micelar crítica de 40-100 mg/L (Mukherjee \& Das, 2010).

Trealolipídeos consistem de um dissacarídeo trealose unido a grupos de ácidos graxos por ligação éster, e são produzidos por vários microrganismos, incluindo os gêneros de Mycobacterium, Rhodococcus, Arthrobacter, Nocardia e Gordonia. Esses biossurfactantes são mais amplamente utilizados em tecnologias de biorremediação já que seus compostos são conhecidos por aumentarem a biodisponibilidade de hidrocarbonetos (Dhanarajan \& Sen, 2014). 


\subsubsection{2.}

\section{Lipopeptídeos}

Os lipopeptídeos consistem em cadeias lineares curtas ou estruturas cíclicas de aminoácidos, unidas a um ácido graxo através de ligações éster ou de amida, ou de ambas. Esses biossurfactantes contêm os aminoácidos raros e modificados, que não são utilizados para a síntese proteica ribossômica, e variam de acordo com os tipos de aminoácidos presentes no anel peptídico, bem como no comprimento da cadeia e na estrutura do componente ácido graxo (Dhanarajan \& Sem, 2014).

Os compostos mais conhecidos desta classe são a surfactina e liquenisina. A Surfactina é um dos biossurfactantes mais eficazes devido à sua atividade surfactante excepcional, tornando-se mais estudado e melhor caracterizado (Mukherjee \& Das, 2010). Esses biossurfactantes apresentam estruturas análogas que possuem diferentes peptídeos e cadeias de ácidos graxos (Jajor et al., 2016), que podem diminuir a tensão superficial da água de $72 \mathrm{mN} / \mathrm{m}$ para $27,9 \mathrm{mN} / \mathrm{m}$, e tem uma concentração micelar crítica de 0,017 g/L (Mukherjee \& Das, 2010).

A liquenisina é um lipopeptídeo cíclico produzido por Bacillus licheniformis, com estrutura e propriedades físico-químicas semelhantes a da surfactina. Esses biossurfactantes possuem elevada atividade surfactante, alcançando uma tensão superficial da água de $29 \mathrm{mN} / \mathrm{m}$ com uma concentração micelar crítica de $15 \mathrm{mg} / \mathrm{L}$ (Coronel-León et al., 2017).

\subsubsection{3. \\ Ácidos graxos e fosfolipídeos}

Várias bactérias e leveduras são capazes de excretar ácidos graxos e fosfolipídeos quando crescem em n-alcanos (Dhanarajan \& Sen, 2014; Hausmann \& Syldatk, 2015).

Os biossurfactantes de ácidos graxos são ácidos graxos saturados com comprimentos de cadeia de $\mathrm{C} 12$ a $\mathrm{C} 14$ e ácidos graxos complexos contendo grupos hidroxilo e ramificações de alquilo. A maior redução das tensões superficiais e de interface foi alcançada por ácidos graxos com comprimentos de cadeia longa (C12 - C14) (Hausmann \& Syldatk, 2015). 
Os fosfolipídeos são a principal parte das membranas microbianas e, normalmente, não estão presentes numa forma extracelular. No entanto, vesículas de membrana extracelular produzidas por Acinetobacter sp. HO1-N crescido com hexadecano foram ricas em fosfolipídeos, principalmente fosfatidiletanolamina e fosfatidilglicerol, e também tinha traços de lipídeos neutros (Dhanarajan \& Sen, 2014). Similarmente, o Rhodococcus erythropolis DSM 43215 também excretou fosfatidiletanolaminas que diminuem a tensão superficial e ocorrem no crescimento em n-alcanos (Hausmann \& Syldatk, 2015).

\subsubsection{4.}

\section{Biossurfactantes poliméricos}

Vários gêneros microbianos, incluindo Acinetobacter, Arthrobacter, Pseudomonas, Halomonas, Bacillus e Candida, foram relatados para produzir biossurfactantes poliméricos. Os biossurfactantes poliméricos não reduzem necessariamente a tensão superficial, mas reduzem eficazmente a tensão interfacial entre líquidos imiscíveis e formam emulsões estáveis. Os biossurfactantes poliméricos mais estudados são o emulsan e o liposan (Dhanarajan \& Sen, 2014).

O biossurfactante emulsan da Acinetobacter calcoaceticus RAG-1 é um bioemulsificador polimérico extracelular potente caracterizado como um heteropolissacarídeo anfipático polianiônico (Mukherjee \& Das, 2010). É um lipopolissacarídeo composto de um heteropolissacarídeo ligado a um ácido graxo através de ligações éster e amida (Dhanarajan \& Sen, 2014).

O liposan é outro emulsionante eficaz produzido por Candida lipolytica capaz de formar emulsões estáveis óleo-em-água. É composto por aproximadamente $83 \%$ de carboidratos e $17 \%$ de proteínas (Dhanarajan \& Sen, 2014).

\subsubsection{5.}

\section{Biossurfactantes particulados}

Alguns exemplos de biossurfactante particulados são as vesículas extracelulares de células microbianas, que ajudam na emulsificação de hidrocarbonetos. A acumulação de vesículas extracelulares com 20-50 mm de 
diâmetro e uma densidade flutuante de $1,158 \mathrm{~g} / \mathrm{cm}^{3}$ foi relatada em células de Acinetobacter sp. HO1-N. As vesículas purificadas são compostas por proteína, fosfolipídeo e lipopolissacarídeo, exibindo uma boa atividade de emulsificação (Dhanarajan \& Sen, 2014; Mukherjee \& Das, 2010).

\subsection{4.}

Microrganismos produtores de biossurfactantes

Existem vários tipos de microrganismos conhecidos que são capazes de produzir biossurfactantes. Dentre os mais importantes cita-se:

As Pseudomonas aeruginosa produzem raminolipídios, os quais são biossurfactantes do tipo glicolipídio (Khoshdast et al., 2012). Enquanto os trealolipídeos e lipopeptídeos são encontrados nas bactérias do gênero Rhodococcus e Bacillus, respectivamente (Franzetti et al., 2010). Outros tipos de microrganismos conhecidos que são capazes de produzir biossurfactantes, são mostrados na Tabela 5 . 
Tabela 5. Classificação dos biossurfactantes produzidos por diferentes microrganismos (Nitschke \& Pastore, 2002).

\begin{tabular}{|c|c|}
\hline Tipo de biossurfactante & Microrganismo \\
\hline \multicolumn{2}{|l|}{ Glicolipídeos } \\
\hline $\begin{array}{l}\text { Raminolipídios } \\
\text { Soforolipídios } \\
\text { Trealolipídios }\end{array}$ & $\begin{array}{c}\text { Pseudomonas aeruginosa } \\
\text { Torulopsis bombicola, Torulopsis apicola } \\
\text { Rhodococcus erythropolis, } \\
\text { Mycobacterium sp }\end{array}$ \\
\hline \multicolumn{2}{|l|}{ Lipopeptídios e lipoproteínas } \\
\hline $\begin{array}{l}\text { Peptídio-lipídio } \\
\text { Viscosina } \\
\text { Serrawetina } \\
\text { Surfactina } \\
\text { Subtilisina } \\
\text { Polimixina } \\
\end{array}$ & $\begin{array}{c}\text { Bacillus licheniformis } \\
\text { Pseudomonas fluorescens } \\
\text { Serratia marcescens } \\
\text { Bacillus subtilis } \\
\text { Bacillus brevis } \\
\text { Bacillus polymyxa }\end{array}$ \\
\hline \multicolumn{2}{|l|}{$\begin{array}{l}\text { Ácidos graxos, lipídios } \\
\text { neutros e fosfolipídios }\end{array}$} \\
\hline $\begin{array}{l}\text { Ácidos graxos } \\
\text { Lipídios neutros } \\
\text { Fosfolípidios }\end{array}$ & $\begin{array}{l}\text { Corynebacterium lepus } \\
\text { Nocardia erythropolis } \\
\text { Thiobacillus thiooxidans }\end{array}$ \\
\hline \multicolumn{2}{|l|}{ Surfatantes poliméricos } \\
\hline $\begin{array}{c}\text { Emulsan } \\
\text { Biodispersan } \\
\text { Liposan } \\
\text { Carboidrato-lipídio-proteína } \\
\text { Manana-lipídio-proteína }\end{array}$ & $\begin{array}{c}\text { Acinetobacter calcoaceticus } \\
\text { Acinetobacter calcoaceticus } \\
\text { Candida lipolytica } \\
\text { Pseudomonas fluorescens } \\
\text { Candida tropicalis }\end{array}$ \\
\hline \multicolumn{2}{|l|}{ Surfatantes particulados } \\
\hline $\begin{array}{l}\text { Vesículas } \\
\text { Células }\end{array}$ & $\begin{array}{c}\text { Acinetobacter calcoaceticus } \\
\text { Várias bactérias }\end{array}$ \\
\hline
\end{tabular}

3.4.5.

Propriedades e vantagens dos biossurfactantes

A eficácia dos surfatantes é determinada através da sua capacidade de reduzir a tensão superficial e interfacial dos sistemas. A tensão superficial que é a medida de energia livre da superfície por unidade de área, necessária para trazer uma molécula do interior do líquido para a superfície (Mulligan, 2005). Enquanto a tensão interfacial é descrito como o trabalho necessário para criar uma nova superfície entre dois fluidos imiscíveis (Saien \& Bahrami, 2016). Além disso, o tipo de carga, comportamento físico-químico, solubilidade e comportamento de 
adsorção são alguns dos mais importantes critérios de seleção para surfactantes (Mulligan, 2005).

As tensões superficial e interfacial estão correlacionadas com a concentração de surfactante até o momento em que a concentração micelar crítica (CMC) é alcançada (Figura 12). A CMC é definida como a concentração mínima de surfactante necessária para atingir valores mais baixos de tensão superficial e interfacial. Com a adição de surfactantes acima da CMC ocorre a associação das moléculas, resultando na formação de micelas, sem afetar a tensão superficial. Desta maneira, mesmo adicionando surfactante acima da $\mathrm{CMC}$, as tensões superficial e interfacial se mantem constantes (Pacheco, 2008).

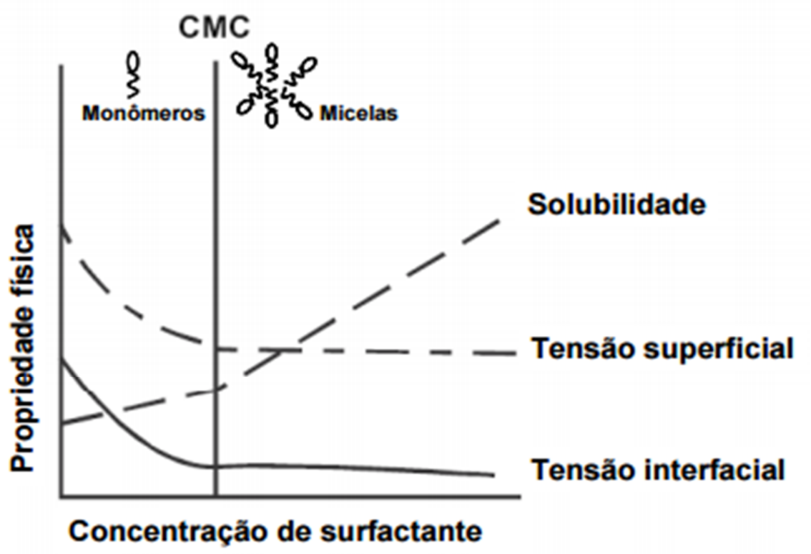

Figura 12. Tensão superficial, tensão interfacial e solubilidade em função da concentração de surfactante (Pacheco, 2008).

As propriedades dos biossurfactantes que os tornam úteis em várias aplicações são apresentadas na Figura 13. 


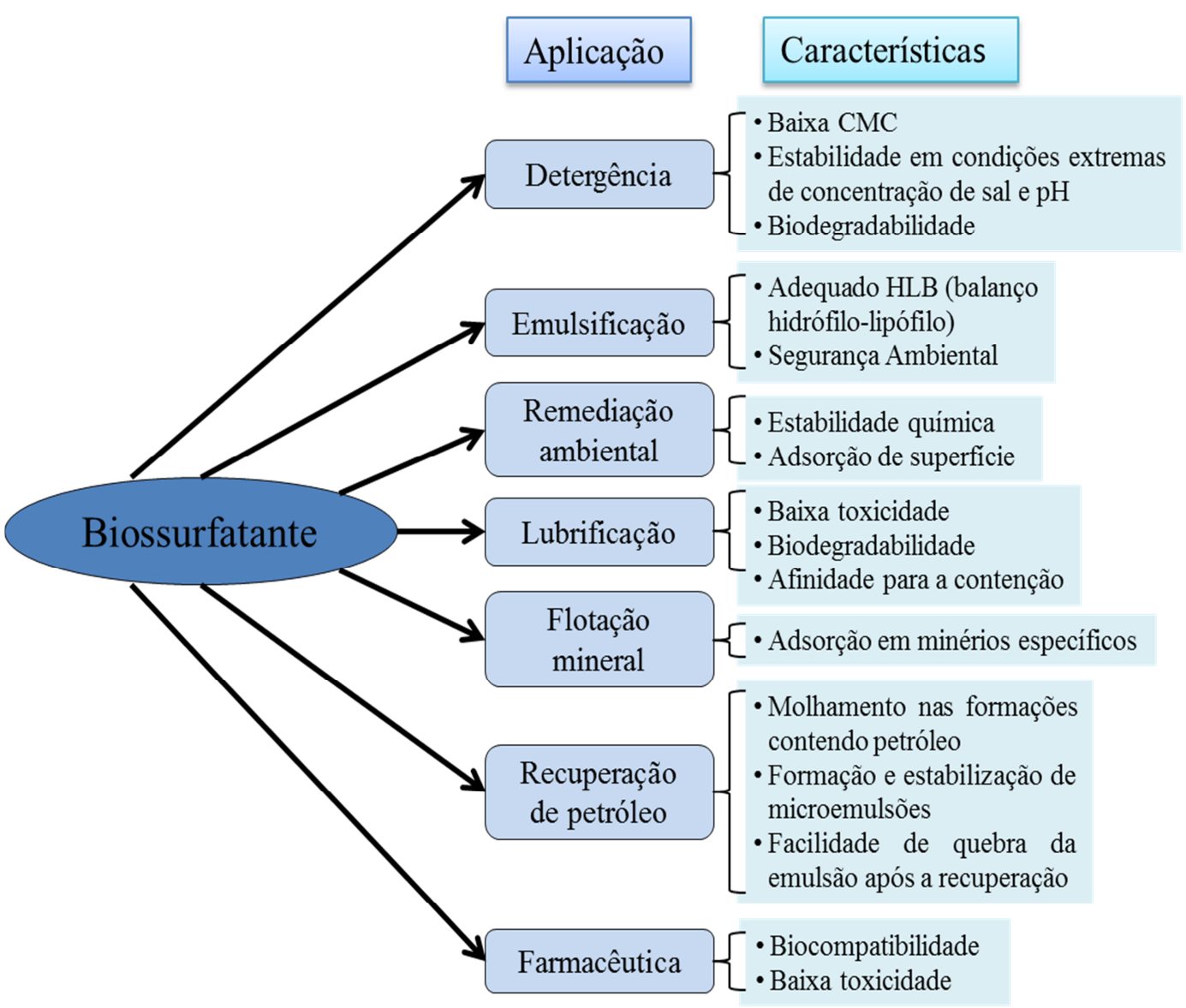

Figura 13. Características dos biossurfactantes úteis em várias aplicações (Khan et al., 2015).

Apesar da diversidade de composição química e propriedades, algumas características são comuns à maioria dos biossurfactantes. Muitas dessas características representam vantagens sobre os surfactantes convencionais. Algumas dessas vantagens são as seguintes (Mulligan et al., 2014):

Biodegradabilidade: Ao contrário dos surfactantes sintéticos, os biossurfactantes são facilmente degradados e particularmente adequados para aplicações ambientais tais como biorremediação e dispersão de derrames de petróleo.

Baixa toxicidade: Os biossurfactantes são geralmente considerados como os produtos de baixa toxicidade ou não tóxicos e, portanto, são apropriados para indústrias farmacêuticas, cosméticas e alimentares.

Biocompatibilidade e digestibilidade: Permite sua aplicação em cosméticos e produtos farmacêuticos e como aditivos alimentares. 
Disponibilidade de matérias-primas: Os biossurfactantes podem ser produzidos a partir de matérias-primas baratas que estão disponíveis em grandes quantidades; a fonte de carbono pode provir de hidrocarbonetos, hidratos de carbono e/ou lipídios, que podem ser utilizados separadamente ou em combinação uns com os outros.

Economia de produção aceitável: Dependendo da aplicação, os biossurfactantes também podem ser produzidos a partir de resíduos industriais e subprodutos, o que é de particular interesse para a produção em massa (por exemplo, para utilização em tecnologias relacionadas com o petróleo).

Especificidade: Os biossurfactantes, sendo moléculas orgânicas complexas com grupos funcionais específicos, são frequentemente específicos na sua ação de interesse.

Eficácia: A temperaturas extremas, $\mathrm{pH}$ e salinidade.

\subsection{6. \\ Estudos de flotação mineral usando biossurfactantes como biorreagente}

Durante alguns anos a produção de biossurfactantes por vários microrganismos tem sido estudada extensivamente, dando origem a uma série de estudos relacionados à sua produção, tipos e propriedades. Como consequência, muitas propriedades comercialmente atrativas e claras vantagens comparadas com os surfactantes químicos têm sido observadas. Dentro deste contexto, produtos microbianos, tais como biossurfactantes, ácidos orgânicos e solventes orgânicos podem também ser aplicados à flotação mineral (Pacheco, 2008).

Zouboulis et al. (2003) utilizaram os biossurfactantes surfactina e liquenisina como coletores de flotação para remover goethita. Os resultados da atividade coletora foram superiores em comparação com dodecilamina e dodecil sulfato de sódio sob as condições experimentais estudadas.

Fazaelipoor et al. (2010) investigaram a utilização do biossurfactante produzido por Pseudomonas aeruginosa como um espumante na flotação de carvão. O estudo mostrou que o biossurfactante é um bom redutor da tensão superficial da água e apresentou boa estabilidade da espuma que poderia ser aplicado com sucesso na flotação de carvão. Similarmente, Khoshdast et al. (2011) demonstraram que o ramnolipídeo produzido por Pseudomonas 
aeruginosa pode ser utilizado como um espumante ou co-espumante promissor nas práticas de processamento mineral.

No trabalho de Patra \& Natarajan (2008) foi avaliado o uso de diferentes frações proteicas extraídas da bactéria Paenibacillus polymyxa como reagente de flotação de quartzo, pirita, calcopirita, esfalerita e galena. Os resultados mostraram que as frações proteicas exibiram uma afinidade de superfície variável para estes minerais que influenciam a sua flotação. Desse modo, a flotabilidade foi favorável para o mineral quartzo, esfalerita e galena.

Vecino et al. (2013) avaliaram o biossurfactante obtido de Lactobacillus pentosus como agente espumante para flotação em espuma. As propriedades de adsorção mostradas pelo biossurfactante de L. pentosus sobre os sedimentos de matéria orgânica apresentaram bons resultados como potencial agente espumante para flotação.

Outros biossurfactantes produzidos por Bacillus mucilaginosus foram utilizados no pré-tratamento da pirolusita para facilitar a remoção de quartzo no processo de flotação Yang et al. (2014b). Também os biossurfactantes de Bacillus circulans e Streptomyces $s p$. foram utilizados na flotação de serpentinita e quartzo (Didyk \& Sadowski, 2012). No trabalho de (Menezes et al., 2011) os efluentes aquosos da drenagem ácida de mina foram tratados utilizando o sistema de flotação por ar dissolvido com biossurfactantes produzidos por Candida lipolytica e Candida sphaerica. 


\section{Materiais e Métodos}

Neste capítulo são apresentados e descritos os materiais, reagentes, equipamentos e procedimentos experimentais que foram empregados no estudo de flotação do sistema hematita-quartzo usando o biossurfactante solúvel produzido por Rhodococcus erythropolis.

\section{5.}

\section{Preparação e caracterização das amostras minerais}

No presente trabalho foram utilizadas amostras minerais puras de quartzo e hematita. Tais amostras foram fornecidas pela empresa MINERAÇÃO ZÉ DA ESTRADA INDÚSTRIA E COMERCIO LTDA de Araçuaí em Minas Gerais Brasil.

A preparação e caracterização das amostras minerais foram realizadas nas instalações do CETEM, de acordo com o fluxograma da Figura 14. Na preparação, as amostras minerais foram reduzidas até o seu tamanho adequado, fazendo uso de operações de britagem, moagem, homogeneização e classificação por peneiramento a úmido. Já, a caracterização e composição mineralógica das amostras minerais foram determinadas fazendo uso das análises em difração de raios $\mathrm{X}(\mathrm{DRX})$ e fluorescência de raios $\mathrm{X}$ (FRX). A análise de difração de raios $\mathrm{X}$ foi obtida pelo método do pó no equipamento Bruker-AXS D5005 equipado com espelho de Goebel para feixe paralelo de raios X, nas seguintes condições de operação: radiação Co $\mathrm{K} \alpha(35 \mathrm{kV} / 40 \mathrm{~mA})$; velocidade do goniômetro de $0,02^{\circ} 2 \theta$ por passo com tempo de contagem de 1,0 segundos por passo e coletados de 5 a $80^{\circ}$ 20. As interpretações qualitativas dos espectros foram efetuadas por comparação com padrões contidos no banco de dados (ICDD, 2006) em software Bruker Diffrac ${ }^{\text {Plus }}$. A análise química por fluorescência de raios $\mathrm{X}$ foi realizada pelo método de fusão com tetraborato de lítio no espectrofotômetro da marca Philips, modelo PW1480. 


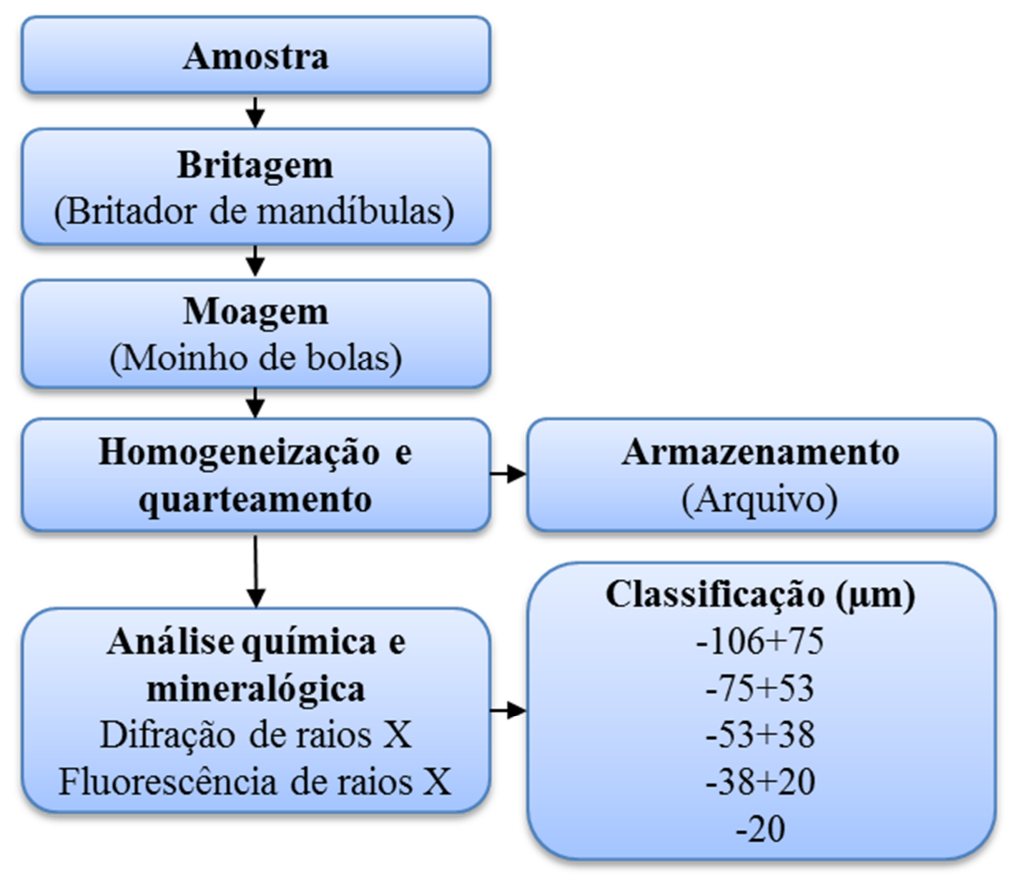

Figura 14. Fluxograma detalhado da preparação das amostras minerais.

As frações granulométricas para cada experimento são distinguidas na Tabela 6.

Tabela 6. Testes e frações granulométricas

\begin{tabular}{c|c}
\hline Testes & Tamanhos de Partícula \\
\hline Potencial Zeta & $<38 \mu \mathrm{m}$ \\
\hline Adsorção & $(-53+38 \mu \mathrm{m})$ \\
\hline Microflotação & $(-106+75 \mu \mathrm{m})$ \\
\hline Ângulo de Contato & $1 \times 1 \times 2 \mathrm{~cm}$ \\
\hline
\end{tabular}

A caracterização e composição mineralógica das amostras minerais foram determinadas fazendo uso das análises em difração de raios $\mathrm{X}$ (DRX) e fluorescência de raios $\mathrm{X}$ (FRX).

\section{6.}

Cultivo e crescimento do Rhodococcus erythropolis

O Rhodococcus erythropolis foi fornecida pela Coleção Brasileira de Microrganismos de Ambiente e Indústria - CBMAI - UNICAMP. 
Fez-se a propagação das bactérias em meio sólido utilizando placas de Petri (Figura 15) e manteve-se em refrigerador a $4^{\circ} \mathrm{C}( \pm 2)$. Todo o material de vidro utilizado e soluções do meio de cultura foram esterilizados em autoclave a $1 \mathrm{~atm}$ de pressão e $121^{\circ} \mathrm{C}$, durante $20 \mathrm{~min}$.

Para a propagação (em meio sólido) e crescimento (em meio líquido) das células Rhodococcus erythropolis, o meio de cultura TSB foi empregado, conforme é mostrado na Tabela 7.

O procedimento de inoculação do microrganismo foi realizado em capela de fluxo laminar previamente esterilizada com lâmpada germicida de luz ultravioleta para evitar que ocorra contaminação microbiana.

\section{Tabela 7. Meio de cultura TSB}

\begin{tabular}{c|c|c}
\hline Componente & $\begin{array}{c}\text { Sólido } \\
(\mathbf{g} / \mathbf{L})\end{array}$ & $\begin{array}{c}\text { Líquido } \\
(\mathbf{g} / \mathbf{L})\end{array}$ \\
\hline Extrato de caseína & 17 & 17 \\
\hline Extrato de farinha de soja & 3 & 3 \\
\hline Cloreto de sódio & 5 & 5 \\
\hline Fosfato dipotássico & 2.5 & 2.5 \\
\hline Glicose & 2.5 & 2.5 \\
\hline Agar & 20 & - \\
\hline $\mathrm{pH}$ & - & 7.2 \\
\hline
\end{tabular}

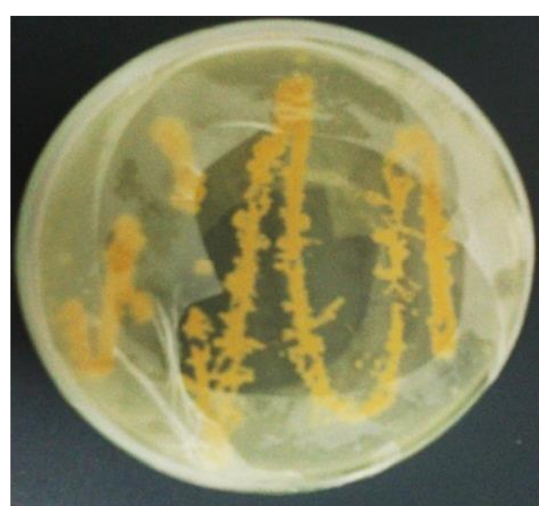

Figura 15. Colônias de Rhodococcus erythropolis em placa de petri. 
A partir das placas de Petri fez-se um subcultivo em meio líquido, utilizando-se frascos Erlenmeyer de $500 \mathrm{~mL}$. Esses frascos foram levados a um shaker rotatório (CIENTEC CT-712) durante 144 horas, a uma temperatura de $28^{\circ} \mathrm{C}$ e $150 \mathrm{rpm}$, para atingir o crescimento máximo do microrganismo e realizarem seus processos metabólicos. Na Figura 16, é mostrado o crescimento das células Rhodococcus erythropolis.

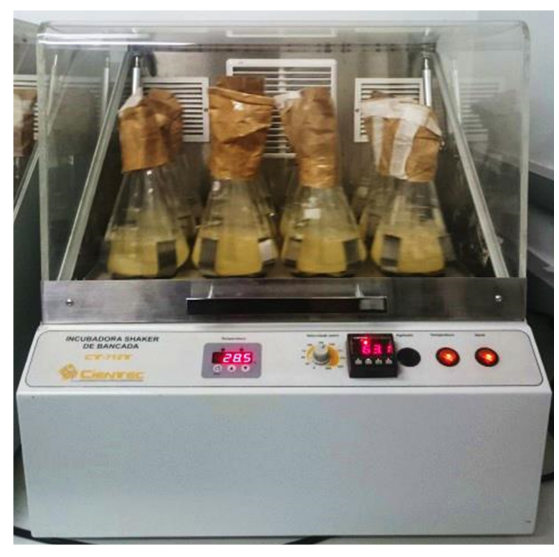

Figura 16. Crescimento bacteriano

\section{7. \\ Caracterização do biossurfactante produzido por Rhodococcus erythropolis}

\subsection{1.}

\section{Processo de extração do biossurfactante}

Após as células atingirem o crescimento máximo e realizarem seus processos metabólicos, o caldo de fermentação foi centrifugada em tubos Falcon de $50 \mathrm{~mL}$ a $5000 \mathrm{rpm}$ durante 8 minutos em centrífuga digital CIENTEC CT5000. O precipitado da centrifugação constituído pelas células bacterianas foi por duas vezes ressuspenso em água deionizada e centrifugado para descartar o meio de cultura remanescente.

A biomassa obtida foi ressuspensa em álcool etílico a $95 \%$ e segue a metodologia realizada no trabalho de Moreau et al. (2003). O fluxograma da extração do biossurfactante solúvel é mostrado na Figura 17 e a metodologia experimental da extração do biossurfactante é detalhada no Apêndice 1. 


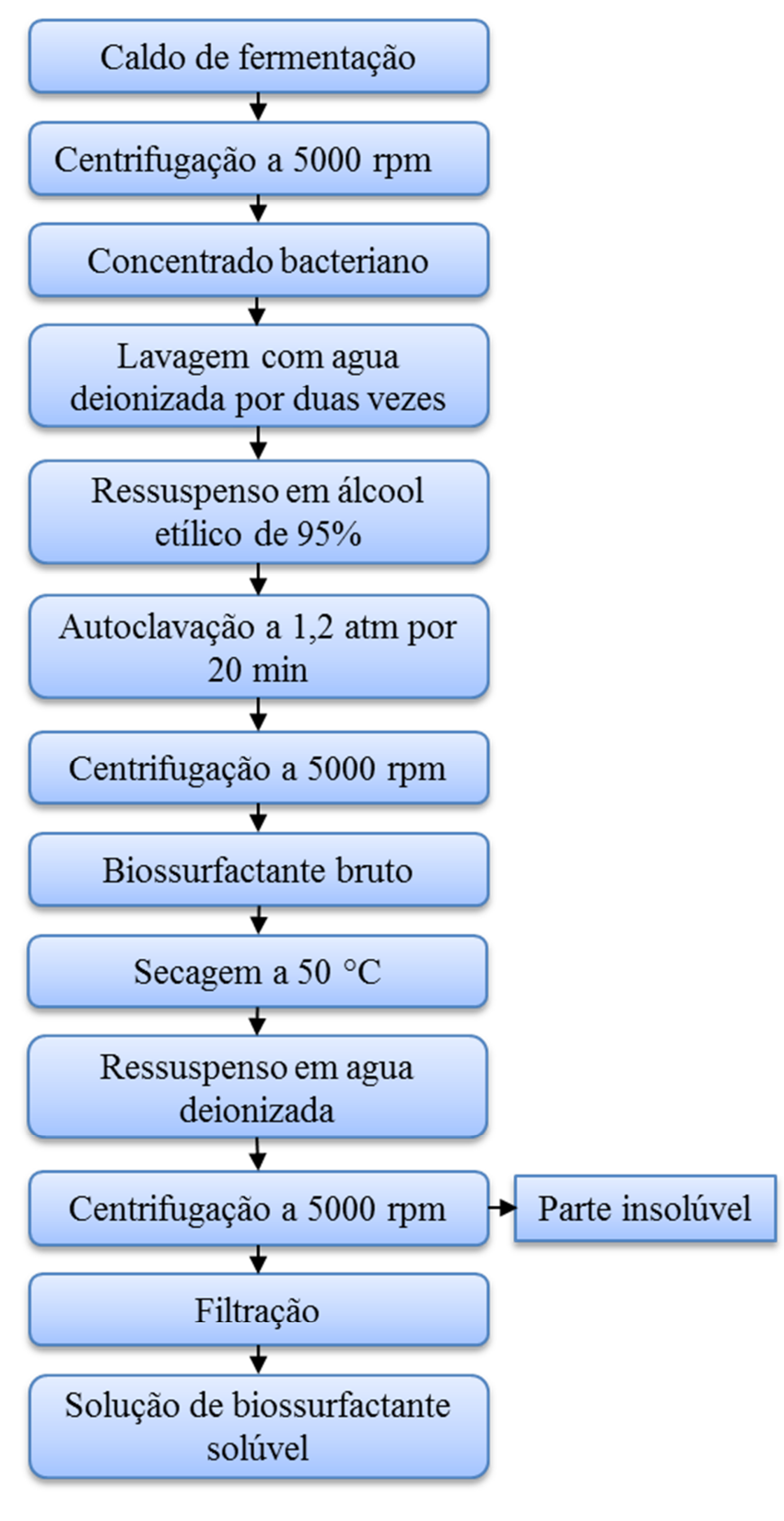

Figura 17. Fluxograma do protocolo de extração do biossurfactante com etanol.

A solução de biossurfactante solúvel pronta para os testes experimentais foi armazenado em balão de vidro de $250 \mathrm{~mL}$ e $\log$ guardado na geladeira a uma temperatura de $4{ }^{\circ} \mathrm{C}$ durante um máximo de 15 dias. 


\subsection{2. \\ Determinação de proteínas, carboidratos e lipídeos presentes no biossurfactante solúvel}

A determinação da composição dos microrganismos e/ou produtos metabólicos permite estabelecer suas relações e comportamentos com a superfície dos minerais (Olivera, 2014). Assim sendo, a quantificação de proteínas, carboidratos e lipídeos presentes no biossurfactante solúvel permitiria predizer e analisar seu comportamento como biorreagente na flotação mineral.

Dentre os vários métodos de análise bioquímica, a determinação de proteínas foi realizada pelo método de biureto (Stickland, 1951), usando albumina do soro bovino (BSA) para a construção da curva padrão de proteínas (Apêndice 2.1 ). Enquanto, a determinação de carboidratos foi realizada pelo método de antrona (Yemm \& Willis, 1954), usando glicose para a construção da curva padrão de carboidratos (Apêndice 2.2). Já a determinação de lipídeos foi realizada pelo método de Bligh e Dyer (1959) que utiliza uma mistura de três solventes: clorofórmio, metanol e água.

\subsection{3. \\ Determinação da tensão superficial do biossurfactante solúvel}

As medidas da tensão superficial foram realizadas no biossurfactante solúvel em função da sua concentração e do $\mathrm{pH}$ da solução, utilizando-se o tensiômetro LAUDA VO2001 equipado com um anel de platina. As soluções foram preparadas com água deionizada e as condições de análise foram padronizadas para todos os ensaios, como volume de solução de $50 \mathrm{~mL}$ e temperatura de $23{ }^{\circ} \mathrm{C}$.

As medidas da tensão superficial em função da concentração do biossurfactante $(0,25,50,75,100,125,150,175$ e $200 \mathrm{mg} / \mathrm{L})$ foram realizadas em pH 3. Já para avaliar a tensão superficial em função do pH da solução $(3,5,7$, 9 e 11) foram preparadas soluções com concentrações do biossurfactante de 100 $\mathrm{mg} / \mathrm{L}$ (valor estimado da concentração micelar critica do biossurfactante).

O valor da concentração micelar critica (CMC) foi dada pelo ponto central da inflexão da curva tensão superficial versus concentração do biossurfactante. 


\section{8. \\ Ensaios de adsorção}

As provas de adsorção foram realizadas em função do $\mathrm{pH}$ para determinar a quantidade de biossurfactante absorvido sobre as superfícies minerais de hematita e quartzo.

Para as experiências de adsorção, foi utilizado $0,25 \mathrm{~g}$ de amostra mineral de $(-53+38 \mu \mathrm{m})$ e água deionizada, em soluções de $35 \mathrm{~mL}$, com diferentes concentrações de biossurfactante $(50,100,150$ e $200 \mathrm{mg} / \mathrm{L})$ e diferentes valores do $\mathrm{pH}(3,5,7,9$ e 11$)$ a $23^{\circ} \mathrm{C}$. Após o condicionamento durante 5 minutos, as soluções foram centrifugadas a $3500 \mathrm{rpm}$ por 8 minutos para separar as fases (mineral e sobrenadante) e logo foram feitas as medições de absorbância de UV do sobrenadante, utilizando o espectrofotômetro Shimadzu UV-1800.

A determinação da quantidade de biossurfactante adsorvido na superfície mineral foi calculada por diferença entre as medições de absorbância da concentração de biossurfactante e o sobrenadante da solução mineralbiossurfactante. A curva de calibração das absorbâncias (215 nm) para as diferentes concentrações de biossurfactante é mostrada no Apêndice 2.3.

\section{9 . \\ Comportamento dos minerais antes e após interação}

\subsection{1. Medidas de potencial zeta}

A fim de identificar as cargas superficiais das amostras em estudo (hematita e quartzo) e avaliar uma possível atração ou repulsão eletrostática entre partículas de natureza diferentes, foram realizados ensaios de mobilidade eletroforética. Essas medidas de potencial zeta para os minerais hematita e quartzo, bem como após sua interação com o biossurfactante foram determinados num equipamento de microeletroforese do tipo Zeta Meter System +4.0.

As suspensões foram preparadas com $100 \mathrm{mg} / \mathrm{L}$ de hematita e de quartzo, separadamente e empregando $\mathrm{NaCl}$ como eletrólito indiferente de $10^{-1} \mathrm{~mol} / \mathrm{L}, 10^{-2}$ $\mathrm{mol} / \mathrm{L}$ e $10^{-3} \mathrm{~mol} / \mathrm{L}$. As amostras de interação mineral-biossurfactante foram obtidas a partir do mineral flotado após uma secagem na estufa a $60{ }^{\circ} \mathrm{C}$ por duas horas. Todas as medições de potencial Zeta foram realizadas em uma faixa de $\mathrm{pH}$ 
de 2 até 11 e o valor de pH desejado para a medição foi ajustado com soluções diluídas de $\mathrm{HCl}$ e $\mathrm{NaOH}$.

\subsection{2.}

\section{Medidas de ângulo de contato}

As medidas de ângulo de contato foram realizadas utilizando-se um Goniômetro modelo Ramé-Hart da COPPE/UFRJ. O objetivo foi avaliar a possível alteração na hidrofobicidade da superfície dos minerais antes e após interação com o biossurfactante.

As seções cortadas dos minerais, medindo $1 \times 1 \times 2 \mathrm{~cm}$ foram moldadas com resina epóxi, conforme é mostrado na Figura 18. Após o embutimento, as amostras foram cuidadosamente lixadas e polidas até chegar ao polimento final de $1 \mu$. As superfícies das seções de cada mineral foram levadas a banho ultrassom durante 2 minutos e logo lavadas com jatos de água deionizada para remover pequenas partículas aderidas.

As medidas de ângulo de contato das superfícies minerais foram realizadas com biossurfactante a uma concentração conhecida $(100 \mathrm{mg} / \mathrm{L})$ e com diferentes valores de $\mathrm{pH}$, ajustados com alíquotas de $\mathrm{HCl}$ e $\mathrm{NaOH}$. Essas medidas foram feitas utilizando o método da gota séssil. Esse estudo experimental consistiu das medidas de ângulo de contato envolvendo gotas de $2 \mu \mathrm{l}$ de líquido na interface mineral/ar.

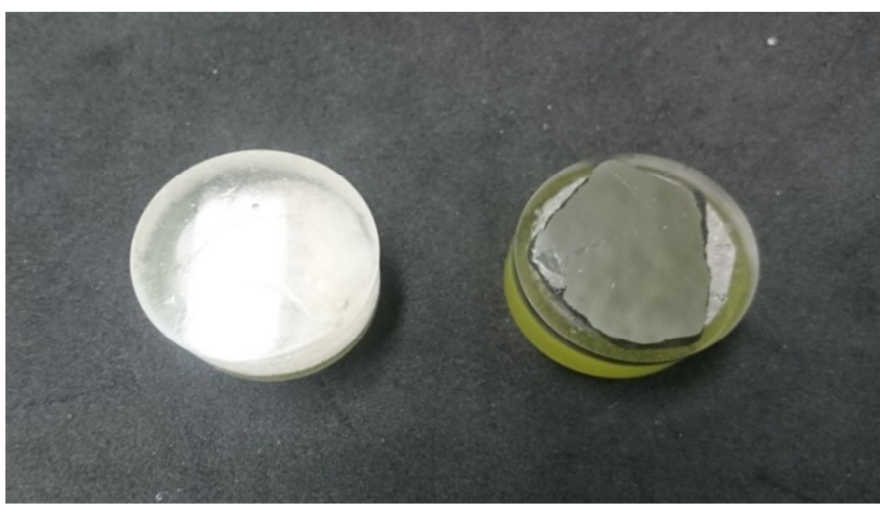

Figura 18- Seções polidas das amostras quartzo e hematita. 


\subsection{3. \\ Espectroscopia no infravermelho (FTIR)}

Os espectros de infravermelho foram realizados no espectrofotômetro FTIR Scientific Nicolet 6700. Estes espectros permitem comparar os grupos funcionais presentes na superfície dos minerais, antes e após interação com o biossurfactante.

Para a obtenção das pastilhas, primeiramente, o pó resultante da secagem de cada amostra foi apropriadamente misturado com uma matriz de brometo de potássio $(\mathrm{KBr})$, numa relação de $1 \%(\mathrm{~m} / \mathrm{m})$. Seguidamente foi obtida a pastilha da mistura homogênea mediante a compressão em um molde. Finalmente, a pastilha obtida foi levada para a realização do espectro no aparelho. Os espectros obtidos em uma resolução de $4 \mathrm{~cm}^{-1}$ usando 120 varreduras.

\subsection{0.}

\section{Ensaios de microflotação.}

Os ensaios de microflotação foram conduzidos em tubo de Hallimond modificado, conforme é mostrado na Figura 19. Todos os testes de microflotação foram realizados em duplicata, empregando $\mathrm{NaCl} 10^{-3} \mathrm{~mol} / \mathrm{L}$ como eletrólito indiferente e $1 \mathrm{~g}$ de amostra mineral. A vazão de ar foi controlada por um rotâmetro previamente calibrado por bolhômetro, garantindo uma vazão de $23 \mathrm{~mL} / \mathrm{min}$. Os tempos de condicionamento e de flotação são de 3 min e 1 min, respectivamente.

Primeiramente, foram realizados estudos preliminares de arraste mecânico dos minerais. Posteriormente, foram realizados os testes de flotabilidade em função do pH na concentração do biossurfactante de $10 \mathrm{mg} / \mathrm{L}$. No pH que resultou o melhor valor de flotação foram realizados testes em função da concentração do biossurfactante. Após determinar os valores ótimos de $\mathrm{pH}$ e concentração do biossurfactante, também foram realizados ensaios de flotação em função do tempo. O pH da solução $(160 \mathrm{~mL})$ foi ajustado com alíquotas de soluções diluídas de $\mathrm{NaOH}$ e $\mathrm{HCl}$, e a porcentagem de flotabilidade foi calculada como a relação de massa entre o material flotado e a massa inicial do material. 


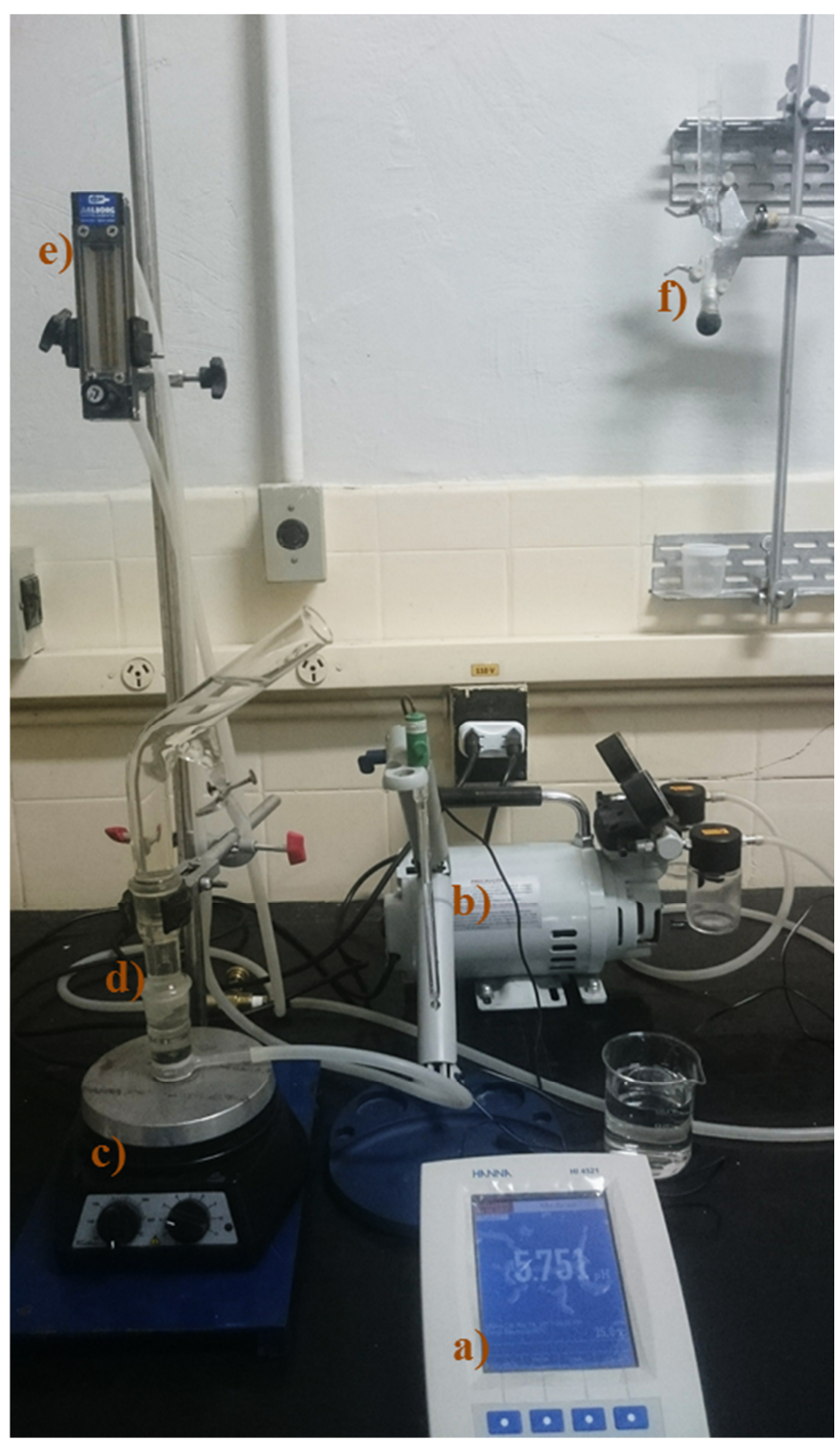

Figura 19. Sistema de microflotação: a) pH-metro, b) Bomba de vácuo e compressor, c) Agitador magnético, d) Tubo de Hallimond modificado, e) Rotâmetro e f) Bolhômetro.

Numa outra etapa, foram realizados ensaios de microflotação usando uma matriz de experimentos, mediante o uso do software Matlab R2012b. O efeito da concentração do biossurfactante $(0,25,50,75,100,125$ e $150 \mathrm{mg} / \mathrm{L})$ e do pH (3, $5,7,9$ e 11) sobre a flotabilidade dos minerais (hematita e quartzo) no processo de microflotação foi avaliado mediante regressão polinomial (onde a aproximação é feita por um polinómio de qualquer ordem usando a função polyfit) e como resultado foram obtidos diagramas de superfícies de resposta e de contornos, assim como também uma função polinomial representativa da microflotação dos 
minerais. A função foi obtida através da aplicação dos critérios de regressão por mínimos quadrados e o efeito dos coeficientes foi analisado mediante o critério do valor-p (probabilidade), usando 0,05 como o limite para a significância estatística. (Devore, 2015). A Tabela 8 mostra a matriz de experimentos utilizada neste estudo, que consta de um total de 35 ensaios.

Tabela 8. Condições experimentais empregadas nos testes de microflotação

\begin{tabular}{|c|c|c|}
\hline $\begin{array}{c}\text { Número do } \\
\text { experimento }\end{array}$ & $\begin{array}{l}\text { Concentração } \\
\text { do BS }(\mathrm{mg} / \mathrm{L})\end{array}$ & pH \\
\hline 1 & 0 & 3 \\
\hline 2 & 25 & 3 \\
\hline 3 & 50 & 3 \\
\hline 4 & 75 & 3 \\
\hline 5 & 100 & 3 \\
\hline 6 & 125 & 3 \\
\hline 7 & 150 & 3 \\
\hline 8 & 0 & 5 \\
\hline 9 & 25 & 5 \\
\hline 10 & 50 & 5 \\
\hline 11 & 75 & 5 \\
\hline 12 & 100 & 5 \\
\hline 13 & 125 & 5 \\
\hline 14 & 150 & 5 \\
\hline 15 & 0 & 7 \\
\hline 16 & 25 & 7 \\
\hline 17 & 50 & 7 \\
\hline 18 & 75 & 7 \\
\hline 19 & 100 & 7 \\
\hline 20 & 125 & 7 \\
\hline 21 & 150 & 7 \\
\hline 22 & 0 & 9 \\
\hline 23 & 25 & 9 \\
\hline 24 & 50 & 9 \\
\hline 25 & 75 & 9 \\
\hline 26 & 100 & 9 \\
\hline 27 & 125 & 9 \\
\hline 28 & 150 & 9 \\
\hline 29 & 0 & 11 \\
\hline 30 & 25 & 11 \\
\hline 31 & 50 & 11 \\
\hline 32 & 75 & 11 \\
\hline 33 & 100 & 11 \\
\hline 34 & 125 & 11 \\
\hline 35 & 150 & 11 \\
\hline
\end{tabular}


Posteriormente, foi avaliada a recuperação de hematita e de quartzo a partir do sistema mineral hematita-quartzo. Para isso, primeiro foram realizados ensaios de flotação do sistema mineral com relações de mistura de 1:3; $1: 1$ e $3: 1$, usando concentrações de 50 e $100 \mathrm{mg} / \mathrm{L}$ do biossurfactante e mantendo o pH da solução em 3. Depois disso, foi avaliado o efeito da concentração de metassilicato de sódio na depressão de quartzo, usando-se concentrações do biossurfactante de 100 $\mathrm{mg} / \mathrm{L}$. Finalmente, foi montado um sistema mineral 1:1 de hematita e quartzo, avaliando-se a recuperação de hematita e de quartzo, em função do $\mathrm{pH}$ e da concentração do metassilicato de sódio. Nesses ensaios foi empregada uma mistura de $0,5 \mathrm{~g}$ de cada amostra mineral e concentrações do biossurfactante de $100 \mathrm{mg} / \mathrm{L}$. A massa flotada, assim como a deprimida, foi recolhida, filtrada, seca e pesada. Sendo assim, para a determinação da quantidade flotada e concentrada do quartzo e da hematita foram realizadas análise química do ferro total por volumetria de oxirredução, utilizando o método de dicromatometria (Jeffery et al., 1989), tal como apresentado no Apêndice 3. O método se baseia na redução do $\mathrm{Fe}^{3+}$ para $\mathrm{Fe}^{2+}$ e consequente titulação do ferro (II) com uma solução de dicromato de potássio (Equação 6):

$$
\mathrm{Cr}_{2} \mathrm{O}_{7}^{2-}+6 \mathrm{Fe}^{2+}+14 \mathrm{H}^{+} \rightarrow 2 \mathrm{Cr}^{3+}+6 \mathrm{Fe}^{3+}+7 \mathrm{H}_{2} \mathrm{O}
$$

\subsection{1.}

\section{Cinética de microflotação}

A cinética de microflotação dos minerais foi avaliada usando o modelo de primeira ordem, modelo de segunda ordem e modelo de ordem fracionária. Os parâmetros e variáveis utilizadas nos ensaios de microflotação tanto do mineral hematita como do quartzo podem ser vistos na Tabela 9. 
Tabela 9. Parâmetros utilizados na determinação da cinética de microflotação mineral.

\begin{tabular}{c|c|c}
\hline Parâmetros e variáveis & Hematita & Quartzo \\
\hline Volume de solução $(\mathrm{mL})$ & 160 & 160 \\
\hline Massa mineral $(\mathrm{g})$ & 1 & 1 \\
\hline $\begin{array}{c}\text { Concentração do } \\
\text { biossurfactante }(\mathrm{mg} / \mathrm{L})\end{array}$ & 10 & 10 \\
\hline Vazão de ar $(\mathrm{mL} / \mathrm{min})$ & 23 & 23 \\
\hline Temperatura $\left({ }^{\circ} \mathrm{C}\right)$ & $23 \pm 2$ & $23 \pm 2$ \\
\hline $\mathrm{pH}$ & 3 & 4 \\
\hline Tempo $(\mathrm{s})$ & $30,60,90,120,150$, & $30,60,90,120,150$, \\
\hline
\end{tabular}




\section{4 \\ Resultados e discussão}

Neste capítulo são apresentados os resultados obtidos ao longo da pesquisa, referentes à caracterização dos minerais utilizados, os estudos eletrocinéticos e adesão, assim como as análises de infravermelho, além dos resultados obtidos do processo de microflotação dos minerais hematita e quartzo usando o biossurfactante solúvel produzido por Rhodococcus erythropolis. Concomitantemente, foi realizada a discussão dos resultados obtidos com trabalhos encontrados na literatura.

\section{1. Preparação e caracterização das amostras minerais}

Os minerais hematita e quartzo utilizados nesta pesquisa foram preparados a partir de operações de britagem, moagem, homogeneização e classificação por peneiramento a úmido, das quais se obteve as frações granulométricas que foram utilizadas para o desenvolvimento da pesquisa.

Os resultados da análise química por fluorescência de raios X é mostrado na Tabela 10. Observa-se que na amostra de hematita encontrou-se um teor de $\mathrm{Fe}_{2} \mathrm{O}_{3}$ em torno de $95,63 \%$ e na amostra de quartzo encontrou-se um teor de $\mathrm{SiO}_{2}$ em torno de $99,05 \%$. 
Tabela 10. Composição química das amostras de hematita e quartzo por fluorescência de raios-X

\begin{tabular}{c|c|c}
\hline \multirow{2}{*}{ Componentes } & \multicolumn{2}{|c}{ Minerais } \\
\cline { 2 - 3 } & Hematita & Quartzo \\
\cline { 2 - 3 } & $<0,10$ & $<0,10$ \\
\hline $\mathrm{Al}_{2} \mathrm{O}_{3}$ & 0,38 & $<0,10$ \\
\hline $\mathrm{SiO}_{2}$ & 0,88 & 99,05 \\
\hline $\mathrm{CaO}$ & $<0,10$ & 0,10 \\
\hline $\mathrm{Fe}_{2} \mathrm{O}_{3}$ & 95,63 & 0,19 \\
\hline $\mathrm{P}_{2} \mathrm{O}_{5}$ & 0,14 & 0,11 \\
\hline $\mathrm{MnO}$ & 0,11 & 0,19 \\
\hline $\mathrm{Outros}$ & 2,66 & - \\
\hline $\mathrm{PPC}$ & - & 0,16 \\
\hline
\end{tabular}

PPC: Perda por calcinação a $1000{ }^{\circ} \mathrm{C}$ por 24 horas

A análise por difração de raios $\mathrm{X}$ dos minerais hematita e quartzo traz os resultados de mineralogia. Esses resultados mostraram que o $\mathrm{Fe}_{2} \mathrm{O}_{3}$ apresenta-se como a fase mineralógica hematita, enquanto o $\mathrm{SiO}_{2}$ apresenta-se como a fase mineralógica quartzo. Os difratogramas das amostras minerais, tanto hematita como quartzo são apresentados na Figura 20 e Figura 21, respectivamente.

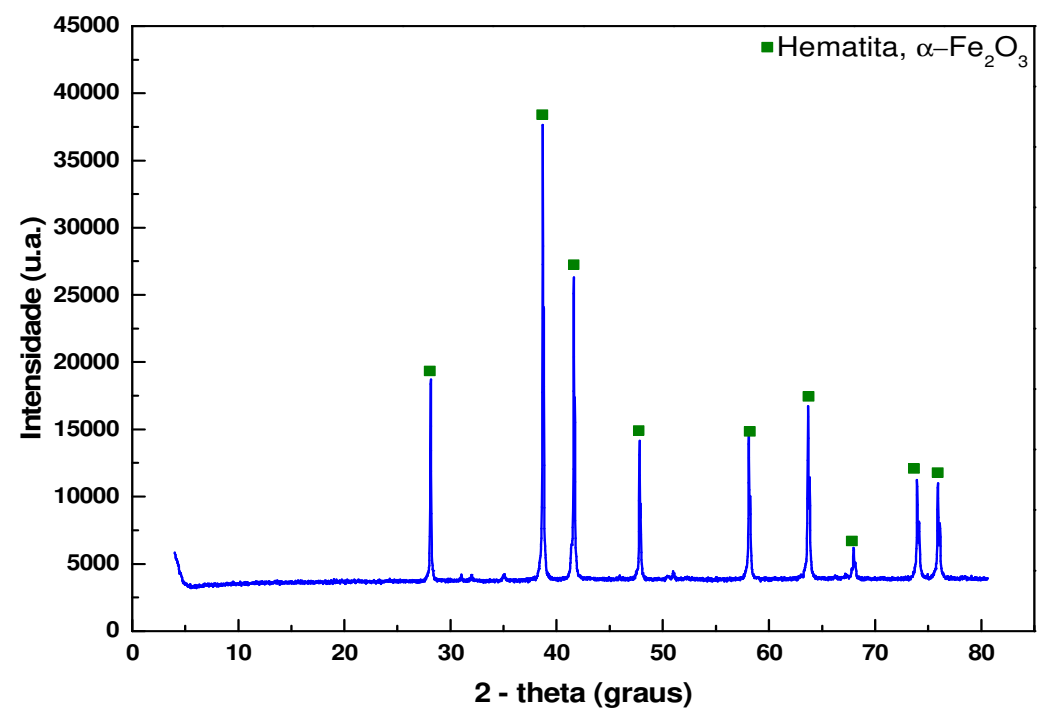

Figura 20. Difratograma da amostra de hematita. 


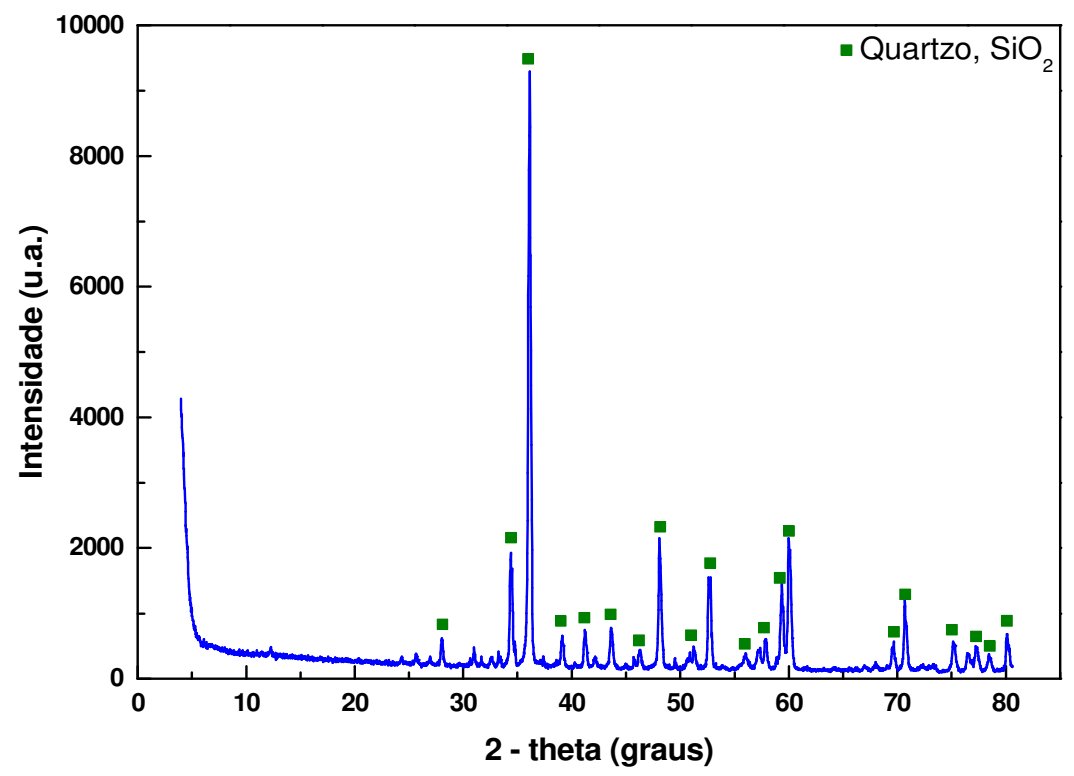

Figura 21. Difratograma da amostra de quartzo.

\section{2. \\ Caracterização do biossurfactante produzido pela bactéria Rhodococcus erythropolis}

\subsection{1. Processo de extração do biossurfactante}

Os membros do gênero Rhodococcus produzem biossurfactantes em resposta à presença de hidrocarbonetos líquidos no meio de crescimento. Estes biossurfactantes são predominantemente glicolipídeos ligados a células contendo trealose. Em termos de características surfactantes, os biossurfactantes de Rhodococcus competem favoravelmente com outros surfactantes microbianos e sintéticos, tendo aplicações potenciais em biotecnologias ambientais e industriais (Kuyukina et al., 2001).

A recuperação e concentração de biossurfactantes a partir do caldo de fermentação determinam largamente o seu custo de produção. Muitas vezes, a baixa concentração e a natureza anfifílica dos surfactantes microbianos limitam sua recuperação (Desai \& Banat, 1997). Várias técnicas utilizadas para a extração de biossurfactante incluem centrifugação a alta velocidade e ultrafiltração, precipitação com ácido e sal, extração com solvente e cromatografia de adsorção (Bryant, 1990; Desai \& Banat, 1997). No entanto, os surfactantes como trealolipídeos associados a células Rhodococcus podem ser eficazmente isolados 
apenas pela extração com solvente orgânico (Lang \& Philp, 1998). Dentre a grande variedade de solventes orgânicos que têm sido utilizados, isoladamente ou em combinação temos o metanol, etanol, éter dietílico, pentano, acetona, clorofórmio e diclorometano (Desai \& Banat, 1997), assim como também o éter metil-butil terciário (MTBE) por ser um solvente menos tóxico e barato (Kuyukina et al., 2001).

Portanto, conhecendo a grande variedade de métodos de extração de biossurfactante, nesta pesquisa foi usado o álcool etílico a 95\% por ser barato e mais popular, e por apresentar baixa toxicidade. Sendo assim, os resultados finais, obtidos após 6 dias de crescimento bacteriano em meio de cultura TSB mostraram que o Rhodococcus erythropolis produz em torno de $165 \mathrm{mg}$ biossurfactante solúvel por litro de caldo de fermentação. Na Figura 22-a é mostrado o biossurfactante bruto, enquanto na Figura 22-b é mostrado o biossurfactante solúvel que foi separado utilizando o processo de centrifugação e filtração.

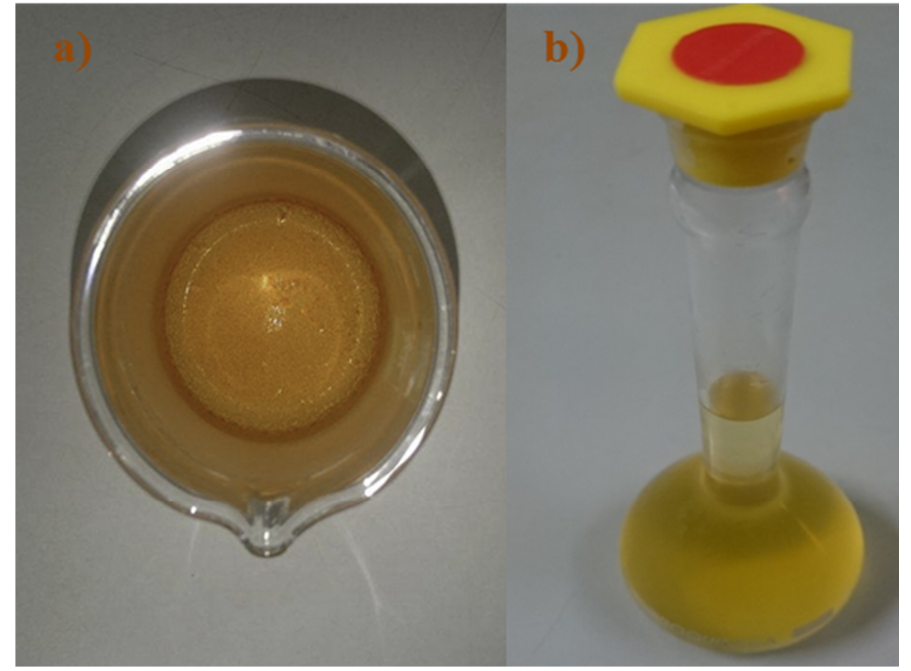

Figura 22. Biossurfactante extraído do Rhodococcus erythropolis: a) Biossurfactante bruto e b) Biossurfactante solúvel.

\subsection{2.}

\section{Determinação de proteínas, carboidratos e lipídeos presentes no} biossurfactante solúvel.

A parede celular das bactérias Gram positivas está composta por altas concentrações de peptideoglicano e muitas outras macromoléculas, incluindo o ácido teicurônico, ácido lipoteicóico, lipopolissacarídeos, lipoproteínas, enzimas e 
ácidos micólicos (Van Der Wal et al., 1997). Existem diversos métodos para estabelecer a composição da parede celular, alguns deles utilizam metodologias tais como raios X, infravermelho e análise bioquímica (Olivera et al., 2017).

A quantidade de proteínas, carboidratos e lipídeos presentes no biossurfactante solúvel foi determinada por análise bioquímica por meio do método de biureto, método de antrona e método de Bligh \& Dyer, respectivamente. Os resultados dessas análises são mostrados na Tabela 11.

\section{Tabela 11. Composição do biossurfactante solúvel.}

\begin{tabular}{c|c|c}
\hline \multirow{2}{*}{ Compostos } & \multicolumn{2}{|c}{ Composição } \\
\cline { 2 - 3 } & $(\mathbf{m g} / \mathbf{m g}$ de BS) & $\%$ \\
\hline Proteínas & $0,6679 \pm 0,0240$ & 66,79 \\
\hline Carboidratos & $0,1073 \pm 0,0177$ & 10,73 \\
\hline Lipídeos & $0,0357 \pm 0,0043$ & 3,57 \\
\hline
\end{tabular}

Da Tabela 11, conclui-se que a composição do biossurfactante solúvel é maior em quantidade de proteínas. Esse fato foi levado em consideração para o processo de flotação devido que as proteínas podem contribuir um carácter hidrofóbico sobre a superfície mineral, enquanto que os polissacáridos proporcionam um carácter hidrofílico (Olivera et al., 2017; Padukone \& Natarajan, 2011; Sharma et al., 2001).

Outros autores como Van Der Wal et al. (1997) determinaram a relação de proteínas e peptideoglicanos com diferentes estirpes bacterianas usando a caracterização de raios X. Os resultados mostraram que o conteúdo de proteínas foi maior na estirpe Bacillus brevis, enquanto que a estirpe Rhodococcus opacus mostrou maior conteúdo de peptideoglicano, com valores de 56\% e 31\%, respectivamente.

Botero (2007) determinou a composição da parede celular da bactéria $R$. opacus mediante análise bioquímica, cujos resultados foram de 2,85\% de proteína, 10,54\% de carboidratos e 33,33\% de lipídios.

Olivera et al. (2017) analisaram a composição da biomassa da bactéria $R$. erythropolis obtida tanto do meio de cultura TSB como do meio de cultura YMG. 
A análise bioquímica mostrou que o conteúdo de proteínas e carboidratos foi maior na biomassa obtida do cultivo em TSB, com valores de 55,12\% e 23,55\%, respectivamente.

\subsection{3.}

\section{Determinação da tensão superficial do biossurfactante solúvel}

As medidas de tensão superficial do biorreagente em função da concentração do biossurfactante foram realizadas no $\mathrm{pH}$ ótimo $(\mathrm{pH}=3)$ de flotação dos minerais estudados, conforme mostrada na Figura 23. Observou-se que a tensão superficial do biorreagente diminui à medida que a concentração do biossurfactante aumentou de 0 a $200 \mathrm{mg} / \mathrm{L}$, apresentando valores de 73,72 e $62,89 \mathrm{mN} / \mathrm{m}$, respectivamente. Essa redução foi devido à presença de substâncias surfactantes trealolipídeos no biorreagente e, foi proporcional à concentração do biossurfactante, até chegarem a CMC (Olivera et al., 2017; Xia et al., 2011). O valor da CMC estimada foi ao redor de $100 \mathrm{mg} / \mathrm{L}$.

A maioria dos biossurfactantes trealolipídeos do gênero Rhodococcus são considerados como biossurfactantes potentes por reduzir a tensão superficial da água de $72 \mathrm{mN} / \mathrm{m}$ a valores entre 19 e $43 \mathrm{mN} / \mathrm{m}$ no valor de CMC entre 0,7 e 37 mg/L após processos de purificação (Christova \& Stoineva, 2014). Merma et al. (2013) estudaram a tensão superficial de uma suspensão de Rhodococcus opacus variando a concentração e o pH. Foi relatado que com uma concentração de biomassa de $300 \mathrm{mg} / \mathrm{L}$ e pH 5,5, a tensão superficial da água pura foi reduzida de 70 para $53 \mathrm{mN} / \mathrm{m}$. Já no trabalho de Olivera et al. (2017) foi estudado a tensão superficial de uma suspensão de Rhodococcus erythropolis. Os resultados mostraram que a tensão superficial da água deionizada foi reduzida de 71,1 para 51,5 mN/m, usando uma concentração de biomassa de 900 mg/L em pH 6. 


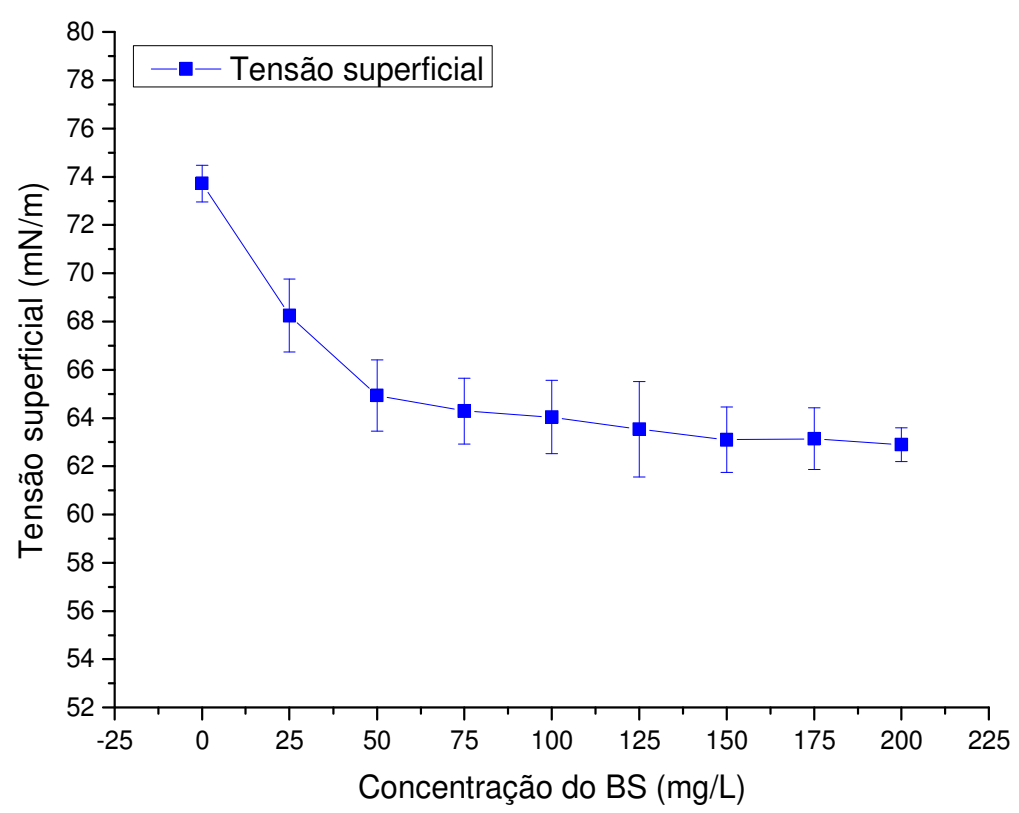

\section{Figura 23. Tensão superficial do biorreagente em função da concentração do biossurfactante: pH 3.}

A Figura 24 mostra o efeito do pH sobre a tensão superficial da interface arbiorreagente. Como pode ser observado, o valor do $\mathrm{pH}$ não afeta significativamente a tensão superficial e permanece quase constante na faixa de $\mathrm{pH}$ entre 5 e 9 , com um valor ao redor de $67 \pm 3 \mathrm{mN} / \mathrm{m}$. Essa pequena diferença pode ser explicada porque, no meio ácido, predominam grupos hidrófobos que têm afinidade para as fases não polares, como o ar. Por outro lado, à medida que o pH aumenta, começa a aparecer espécies aniônicas, diminuindo conseqüentemente sua afinidade pelo ar (Olivera et al., 2017).

Outros autores como Merma et al. (2013) estudaram o efeito do pH na tensão superficial das suspensões de biomassa do Rhodococcus opacus. Observou-se que a tensão superficial diminuiu significativamente abaixo do $\mathrm{pH} 7$, atingindo o seu menor valor de $54,5 \mathrm{mN} / \mathrm{m}$ em torno do $\mathrm{pH} 3$. Similarmente, Olivera et al. (2017) estudaram o efeito do pH na tensão superficial das suspensões de biomassa do Rhodococcus erythropolis. Os resultados mostraram que o valor do pH não afeta significativamente a tensão superficial e permanece quase constante, com um valor de $55 \pm 3 \mathrm{mN} / \mathrm{m}$. 


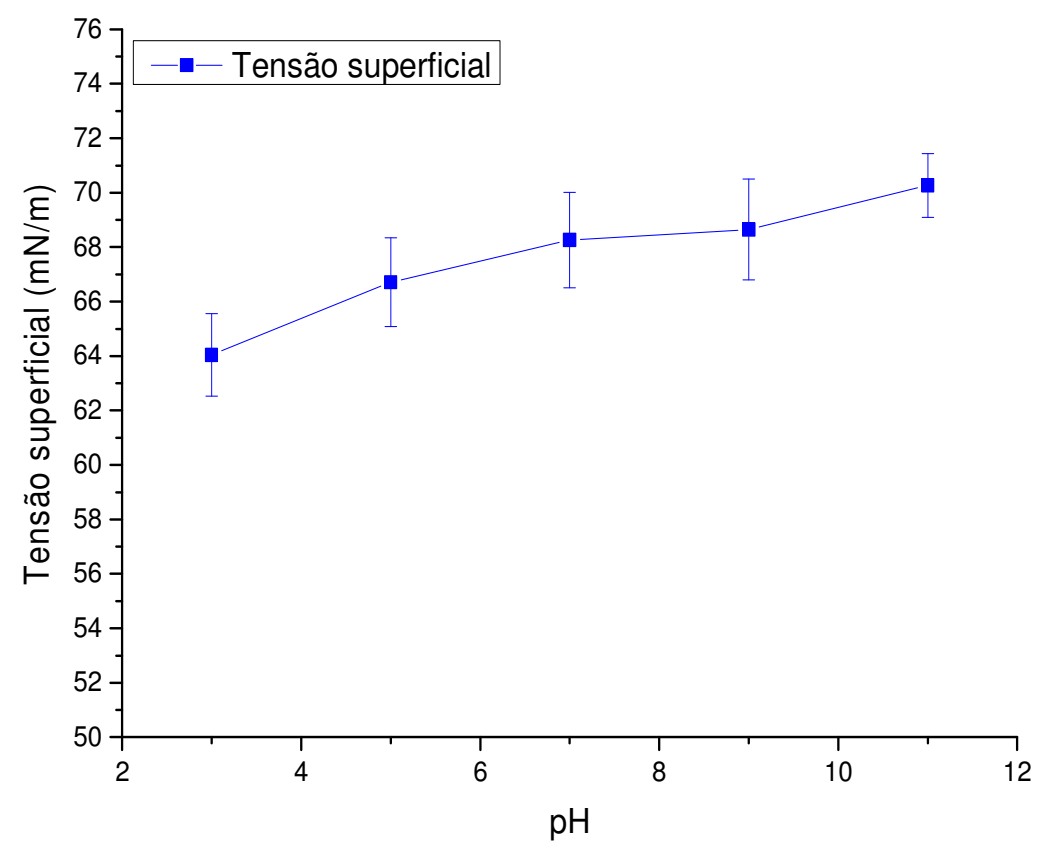

Figura 24. Tensão superficial do biorreagente em função do pH (concentração do biossurfactante: $100 \mathrm{mg} / \mathrm{L}$ ).

\subsection{4. Espectroscopia no infravermelho do biossurfactante solúvel}

A Figura 25 apresenta o espectrograma de infravermelho do biossurfactante, mostrando as principais bandas. Essas bandas foram interpretadas a partir dos resultados encontrados na literatura (Garip et al., 2009; Olivera et al., 2017; Pavlovic \& Brandao, 2003; Yang et al., 2013a, 2014a). Sendo assim, a banda $3417,64 \mathrm{~cm}^{-1}$ é atribuída às vibrações de estiramento de grupos $\mathrm{OH}$ e $\mathrm{NH}$; as bandas em regiões entre 3000-2800 são características do estiramento $\mathrm{C}-\mathrm{H}$ dos grupos $\mathrm{CH}_{2}$ e $\mathrm{CH}_{3}$; a banda $1634,34 \mathrm{~cm}^{-1}$ é característica do estiramento $\mathrm{C}=\mathrm{O}$ da amida I na proteína; as bandas entre $1500-1300 \mathrm{~cm}^{-1}$ correspondem às vibrações de flexão dos grupos $\mathrm{CH}_{2}$ e $\mathrm{CH}_{3}$; a banda $1080,28 \mathrm{~cm}^{-1}$ é característica do estiramento assimétrico de grupos fosfato em ácidos teicóicos e aos modos complexos de vibração dos polissacarídeos; a banda 1048,68 $\mathrm{cm}^{-1}$ é atribuída ao estiramento do grupo alcoólico primário $\left(\mathrm{CH}_{2} \mathrm{OH}\right)$ e a banda $543,04 \mathrm{~cm}^{-1}$ pode ser atribuída às vibrações de balanço do grupo $\mathrm{CH}_{2}$. 


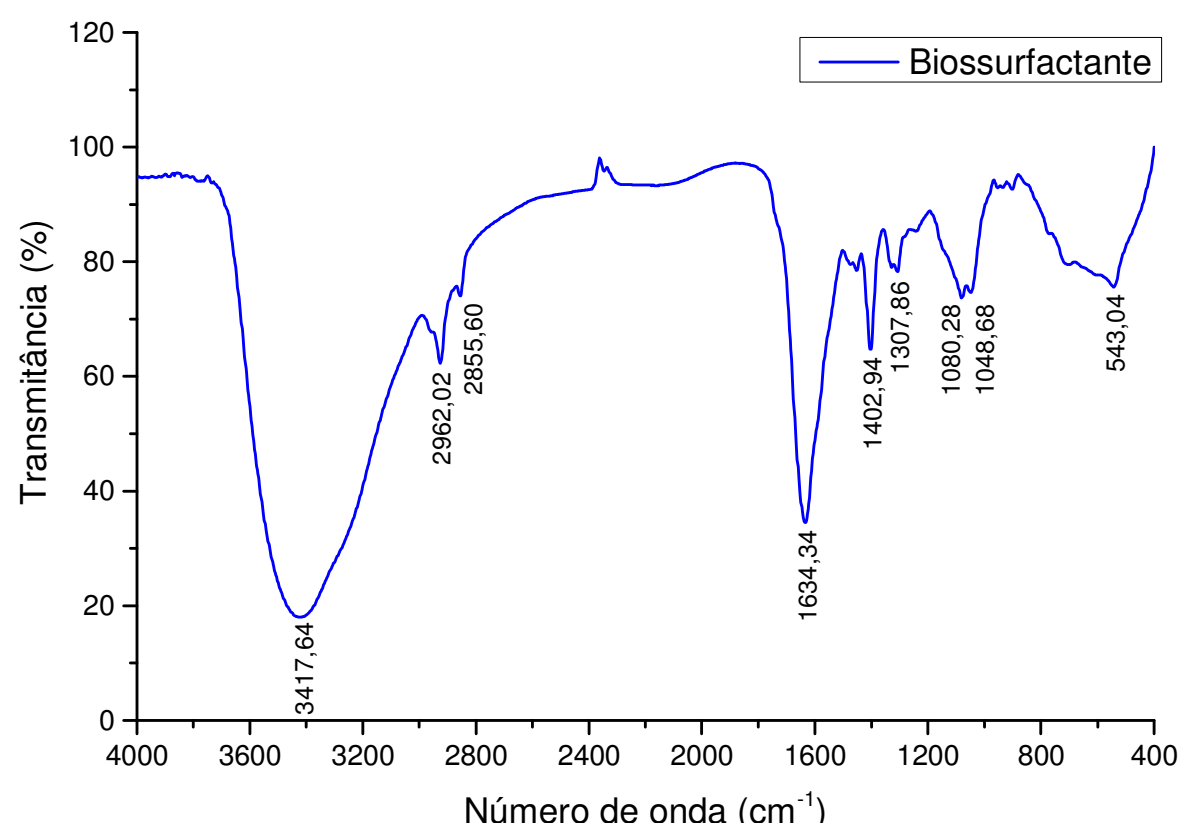

Figura 25. Espectro de FTIR de transmitância do biossurfactante.

\section{3. \\ Comportamento dos minerais antes e após interação com o biossurfactante}

\subsection{1.}

\section{Estudos de potencial zeta}

Com o objetivo de avaliar uma possível variação nas propriedades eletrocinéticas dos minerais, foram realizadas medidas de potencial zeta tanto para a hematita quanto para o quartzo.

\subsubsection{1.}

\section{Potencial zeta da hematita}

A Figura 26 apresenta os resultados obtidos nas medições de potencial zeta da hematita, na presença de cloreto de sódio como eletrólito indiferente, nas concentrações de $10^{-1} \mathrm{~mol} / \mathrm{L}, 10^{-2} \mathrm{~mol} / \mathrm{L}$ e $10^{-3} \mathrm{~mol} / \mathrm{L}$, em diferentes valores de $\mathrm{pH}$. As partículas de hematita apresentaram um ponto isoelétrico (PIE) em torno do $\mathrm{pH} 5,2$; observando-se também que para valores de $\mathrm{pH}$ inferiores ao do PIE o potencial zeta é unicamente positivo, enquanto que para valores superiores a este os potenciais medidos são negativos. $\mathrm{O}$ valor do $\mathrm{PIE}(\mathrm{pH}=5,2)$ obtido é similar 
com os valores encontrados por Deo \& Natarajan (1997), Yang et al. (2013b) e Olivera et al. (2017), onde seus valores de PIE foram na faixa de $\mathrm{pH}$ 5,0 - 6,0.

Nas três concentrações investigadas, $10^{-1} \mathrm{~mol} / \mathrm{L}, 10^{-2} \mathrm{~mol} / \mathrm{L}$ e $10^{-3} \mathrm{~mol} / \mathrm{L}$, identificou-se o mesmo PIE, indicando que o aumento da concentração de $\mathrm{NaCl}$ provocou diminuição da magnitude do potencial da hematita, sem alterar o ponto isoelétrico $(\mathrm{pH}=5,2)$. Segundo Hunter (1981) está diminuição está associada ao efeito de compressão da dupla camada elétrica e ao acúmulo de contra-íons, causados pelo aumento da força iônica do sistema.

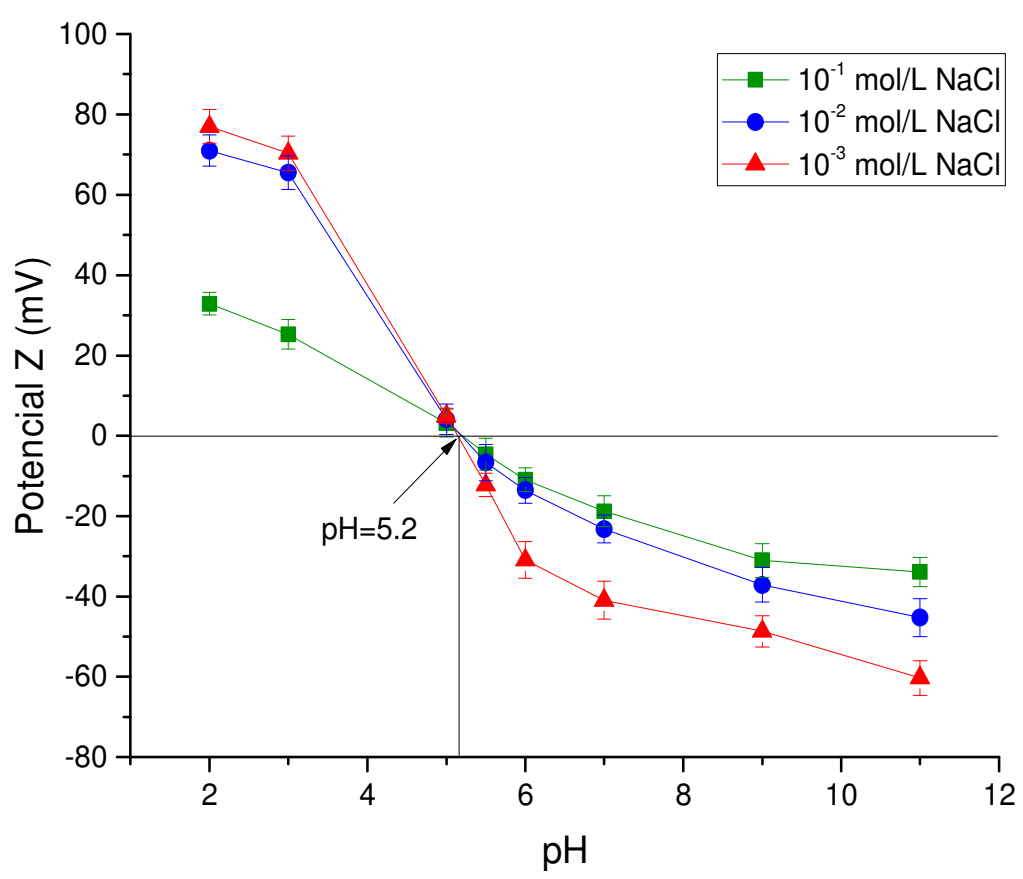

Figura 26. Perfis de potencial zeta da hematita em diferentes concentrações de eletrólito indiferente.

A Figura 27 apresenta os perfis de potencial zeta da hematita, antes e após interação com o biossurfactante. Antes da interação, os valores de potencial zeta demonstraram relativa estabilidade das partículas de hematita em valores próximos de $65 \mathrm{mV}$ na faixa ácida e valores em torno de $-35 \mathrm{mV}$ na faixa alcalina. Esses valores mostram a flexibilidade da hematita para interagir com um surfactante aniônico em meio ácido e surfactante catiônico em meio básico.

Após a interação da hematita com o biossurfactante se observou uma mudança nas propriedades de superfície do mineral principalmente, na faixa de pH 3 até 7. A hematita apresenta diminuição no valor do seu potencial, assim 
como o deslocamento no valor de $\mathrm{pH}$ correspondente ao PIE, mudando de $\mathrm{pH}$ 5,2 para $\mathrm{pH} 4,4$. Esse resultado pode ser devido às interações surfactantes ocorrido na superfície de hematita (Olivera et al., 2017; Raichur et al., 1996; Subramanian et al., 2003; Vilinska \& Rao, 2008).

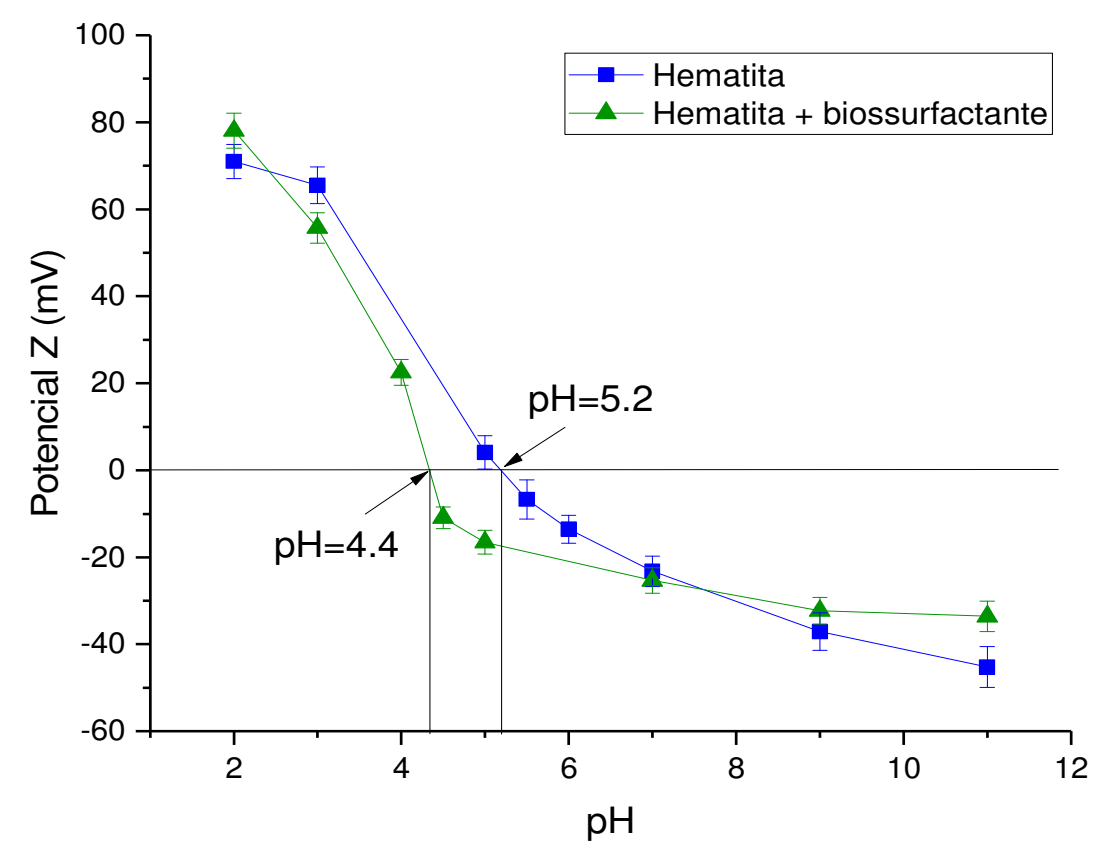

Figura 27. Perfis de potencial zeta da hematita antes e após a interação com o biossurfactante. Concentração de eletrólito indiferente: $\mathrm{NaCl} 10^{-2} \mathrm{~mol} / \mathrm{L}$.

\subsubsection{2.}

Potencial zeta do quartzo

O potencial zeta do quartzo foi realizado nas mesmas condições que foram estabelecidas para o potencial zeta do mineral hematita. A Figura 28 apresenta os resultados das medições de potencial zeta realizadas na faixa de $\mathrm{pH}$ 1,5 até 11 . As partículas de quartzo são carregadas negativamente para a faixa de $\mathrm{pH}$ acima do PIE $(\mathrm{pH}=1,9)$, com uma diminuição da magnitude potencial quando a concentração de eletrólito indiferente foi elevado de $10^{-3} \mathrm{M}$ para $10^{-1} \mathrm{M}$. O valor do PIE do quartzo é relativamente próximo com os valores encontrados em outros trabalhos, onde seus valores está na faixa de pH 2 até 3 (Mesquita et al., 2003; Yang et al., 2013a). 


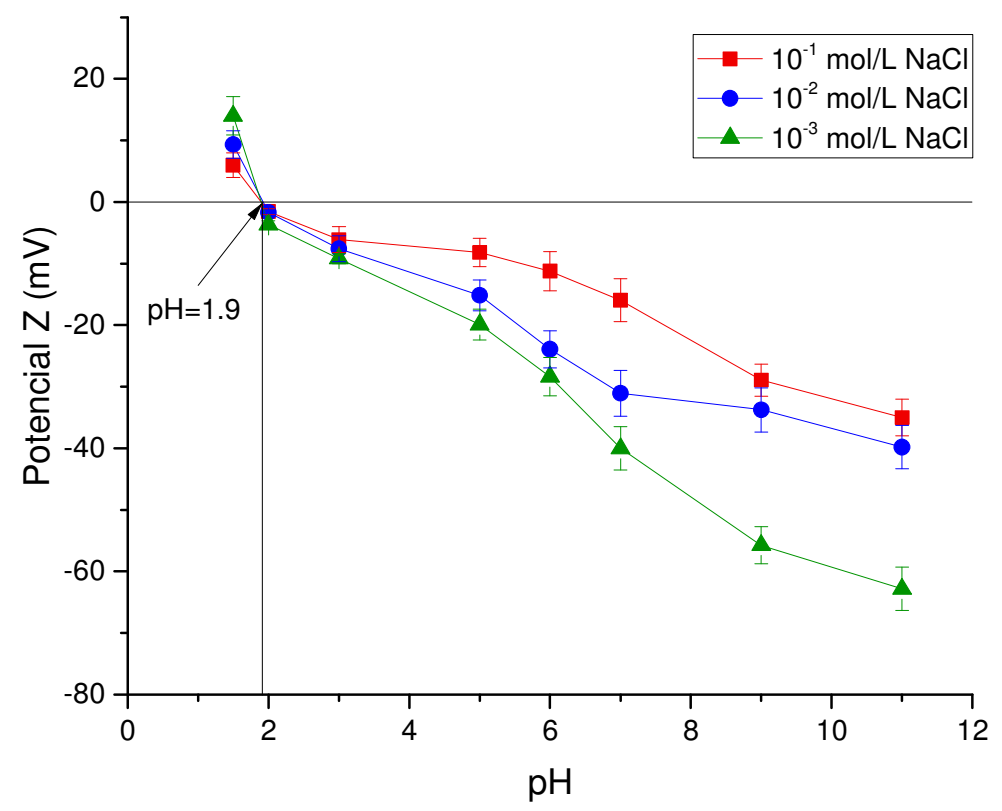

Figura 28. Perfil de potencial zeta do quartzo em diferentes concentrações de eletrólito indiferente.

A Figura 29 apresenta os perfis de potencial zeta do quartzo, antes e após interação com o biossurfactante. Antes da interação, os valores de potencial zeta demonstraram relativa estabilidade das partículas de quartzo em valores em torno de $-30 \mathrm{mV}$ na faixa alcalina.

Após a interação do quartzo com o biossurfactante, os estudos de potencial zeta mostram claramente que existe uma mudança nos valores de potencial zeta, obtendo-se um valor do PIE em torno de $\mathrm{pH} 4,4$. Essa mudança nas propriedades da superfície mineral pode ser causada pela adsorção do surfactante na superfície do quartzo e pelas possíveis interações surfactantes (Olivera et al., 2017; Raichur et al., 1996; Subramanian et al., 2003; Vilinska \& Rao, 2008). 


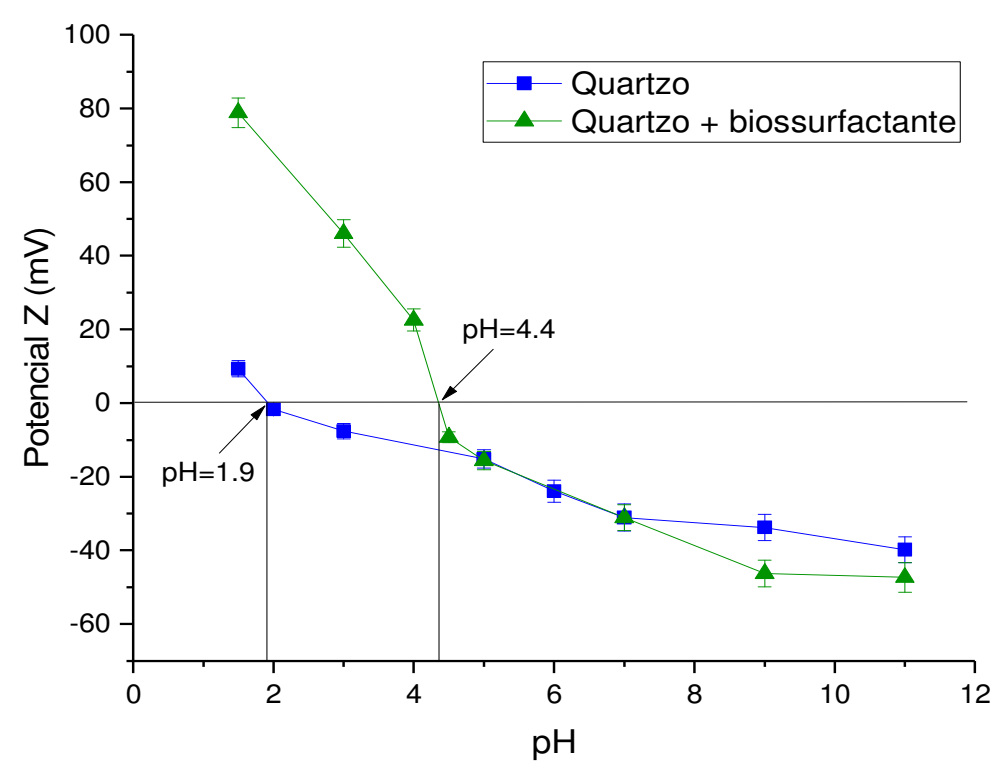

Figura 29. Perfis de potencial zeta do quartzo antes e após a interação com o biossurfactante. Concentração de eletrólito indiferente: $\mathrm{NaCl} 10^{-2} \mathrm{~mol} / \mathrm{L}$.

\subsection{2.}

Medidas de ângulo de contato

As medidas de ângulo de contato foram realizadas para comprovar a hidrofobicidade dos minerais, antes e após da interação com o biossurfactante. Os resultados das medidas de ângulo de contato das superfícies minerais antes da interação com o biossurfactante foram realizadas em pH 7 e são mostrados na Tabela 12.

Tabela 12. Ângulo de contato de hematita e quartzo sem interação com o biossurfactante.

\begin{tabular}{c|c}
\hline Mineral & Ângulo de contato $\left(^{\circ}\right)$ \\
\hline Hematita & $31,5 \pm 8,65$ \\
\hline Quartzo & $10,2 \pm 5,15$ \\
\hline
\end{tabular}

Antes da interação com o biossurfactante, as superfícies de hematita e quartzo apresentaram um baixo caráter hidrófobo, cujos valores de ângulo de contato são de $31,5^{\circ}$ e $10,2^{\circ}$, respectivamente. Porem após interação, as 
superfícies de hematita e quartzo tiveram um aumento do caráter hidrófobo, constatado pelo aumento do ângulo de contato.

A Figura 30 mostra as medidas de ângulo de contato da hematita, realizadas em função do pH. Observa-se que as medidas dos ângulos de contato indicam que há uma forte interação entre o biossurfactante e a superfície de hematita. A maior medida de ângulo de contato foi alcançada na faixa de $\mathrm{pH}$ ácida, principalmente no $\mathrm{pH} 3$ e 4, com valores ao redor de $56^{\circ}$. Esses valores foram diminuindo conforme o pH da solução foi aumentando até 11.

No trabalho de Mesquita et al. (2003) verificaram o caráter hidrofóbico da hematita pelo aumento dos valores do ângulo de contato, antes e após interação com as células Rhodococcus opacus. Antes da interação a superfície da hematita apresentou valores de ângulo de contato nulos (caráter hidrofílico), enquanto após interação foi verificado um leve caráter hidrofóbico, com valores de $31-36^{\circ}$ na faixa de $\mathrm{pH} 3$ até 5.

Peçanha (2014) observou que a superfície da hematita apresentou mudança em suas propriedades físico-químicas após interação com as células de B. subtilis. O valor do ângulo de contato do mineral passou de $27,40^{\circ}$ para $46,04^{\circ}$, indicando que o biorreagente teria atribuído um caráter hidrofóbico à hematita.

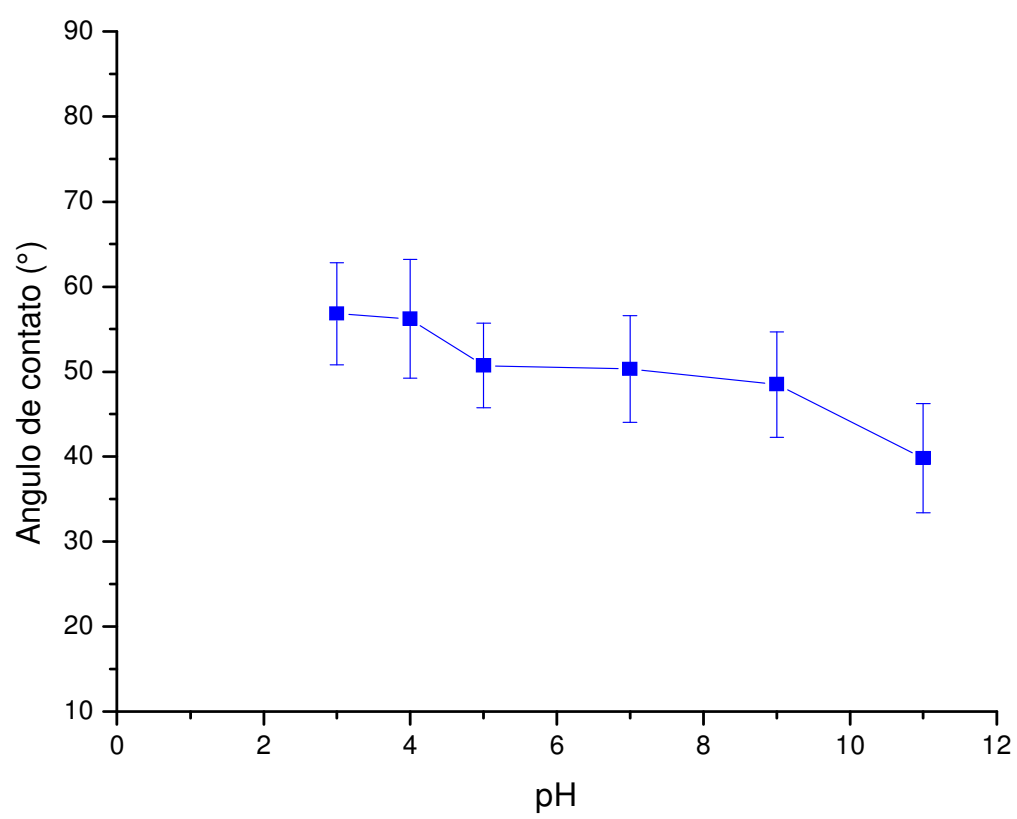

Figura 30. Medidas de ângulo de contato da hematita após interação com o biossurfactante. Concentração do biossurfactante: $100 \mathrm{mg} / \mathrm{L}$. 
Para o quartzo, os resultados das medidas de ângulo de contato também mostraram modificação da superfície do mineral após interação com o biossurfactante, conforme é mostrado na Figura 31. Observa-se que a maior medida de ângulo de contato foi alcançada no $\mathrm{pH} 3$, com um valor em torno de $39^{\circ}$. Já para valores do $\mathrm{pH}$ acima de 3 , essas medidas foram diminuindo conforme o pH da solução foi mais alcalino.

Outros autores também observaram mudanças nos valores de ângulos de contato da superfície do quartzo após a interação celular. Os resultados de Mesquita et al. (2003) apresentaram uma variação dos valores do ângulo de contato entre $13^{\circ}$ e $20^{\circ}$ na faixa de $\mathrm{pH}$ ácido. Já Merma et al. (2013) observaram uma variação do ângulo de contato ao redor de $20^{\circ}$ no $\mathrm{pH} 5$.

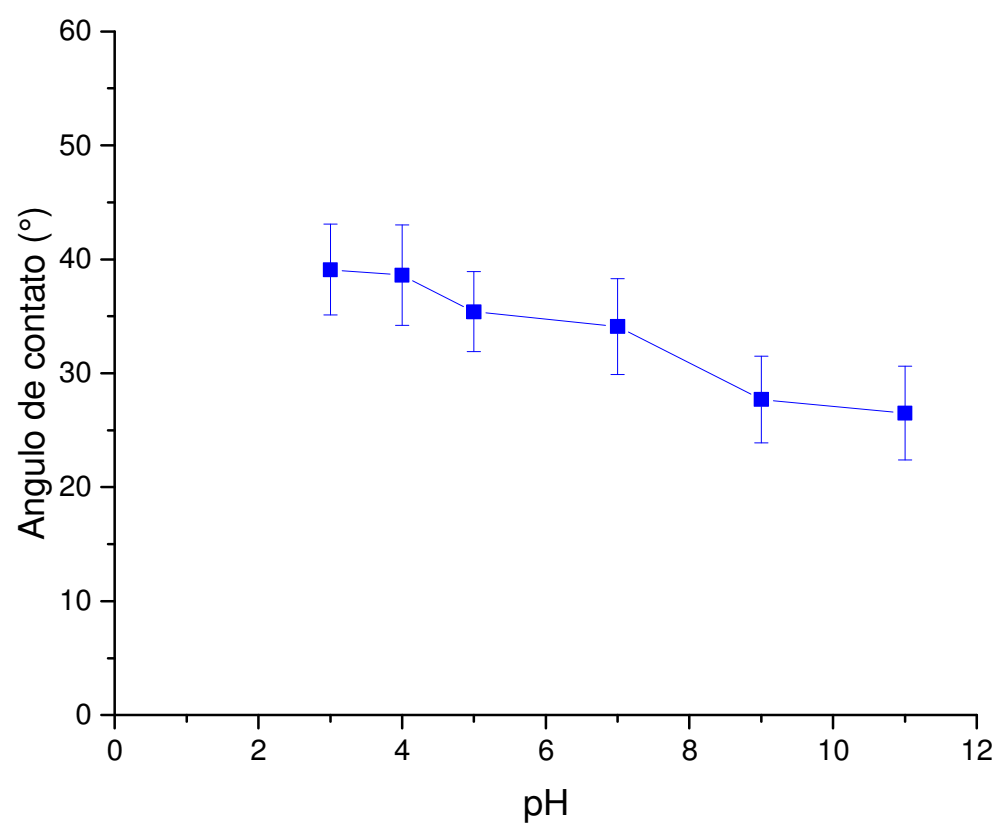

Figura 31. Medidas de ângulo de contato do quartzo após interação com o biossurfactante. Concentração do biossurfactante: $100 \mathrm{mg} / \mathrm{L}$.

Os resultados obtidos indicam claramente uma forte interação entre o biossurfactante e as amostras de quartzo e hematita, com uma forte influência do pH da solução. Esses mesmos resultados reforçam os resultados encontrados nas medidas de potencial zeta e experimentos de adsorção. 


\subsection{3.}

\section{Espectroscopia no infravermelho}

Os diferentes espectros no infravermelho foram realizados com o intuito de avaliar a interação da superfície da hematita e de quartzo com os grupos funcionais do biossurfactante.

\subsubsection{1.}

\section{Espectroscopia no infravermelho do mineral hematita}

Os espectrogramas de infravermelho do mineral hematita, antes e após interação com o biossurfactante, são mostrados na Figura 32 e Figura 33, respectivamente. Antes da interação, a superfície de hematita mostrou grupos hidroxila $(\mathrm{OH})$ e vibrações de estiramento $(\mathrm{Fe}-\mathrm{O})$. A banda $3432,41 \mathrm{~cm}^{-1}$ indica o grupo hidroxila, enquanto as bandas $545,99 \mathrm{~cm}^{-1}$ e $466.94 \mathrm{~cm}^{-1}$ indicam que a hematita tem absorção intensa pelas vibrações de estiramento.

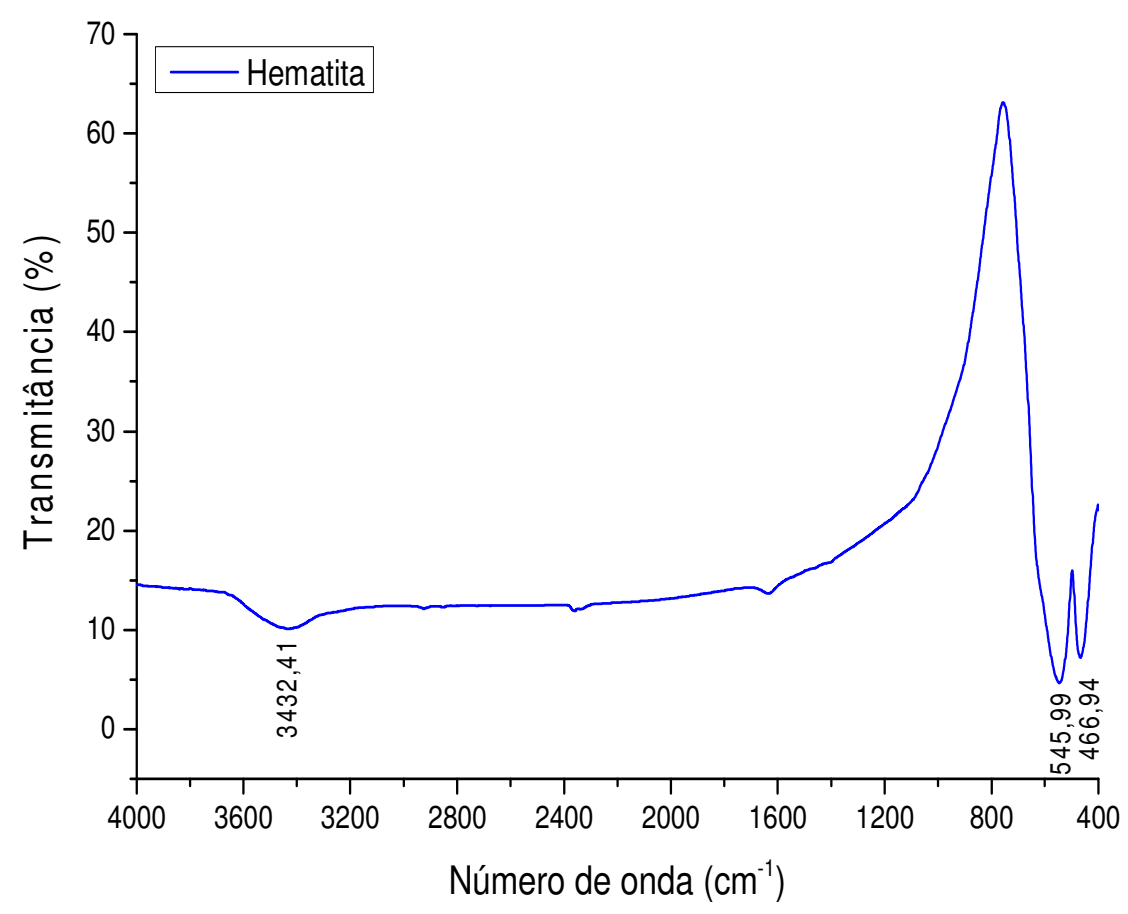

Figura 32. Espectro de FTIR de transmitância do mineral hematita.

Após interação, observou-se que a superfície de hematita contem seis grupos característicos do biossurfactante que foram deslocados em diferentes direções, entre eles: as vibrações de estiramento de grupos $\mathrm{OH}$ e $\mathrm{NH}$ mudaram de 
$3417,64 \mathrm{~cm}^{-1}$ para $3426,48 \mathrm{~cm}^{-1}$; o estiramento $\mathrm{C}-\mathrm{H}$ dos grupos $\mathrm{CH}_{2}$ e $\mathrm{CH}_{3}$ mudaram de $2962,02 \mathrm{~cm}^{-1}$ para 2925,98 $\mathrm{cm}^{-1}$; o estiramento $\mathrm{C}=\mathrm{O}$ da amida I na proteína mudou de $1634,34 \mathrm{~cm}^{-1}$ para $1630,63 \mathrm{~cm}^{-1}$; as vibrações de flexão dos grupos $\mathrm{CH}_{2}$ e $\mathrm{CH}_{3}$ mudaram de 1402,4 e $1307,86 \mathrm{~cm}^{-1}$ para 1403,76 e 1316,52 $\mathrm{cm}^{-1}$, respectivamente e, o estiramento assimétrico de grupos fosfato mudou de $1080,28 \mathrm{~cm}^{-1}$ para $1080,98 \mathrm{~cm}^{-1}$.

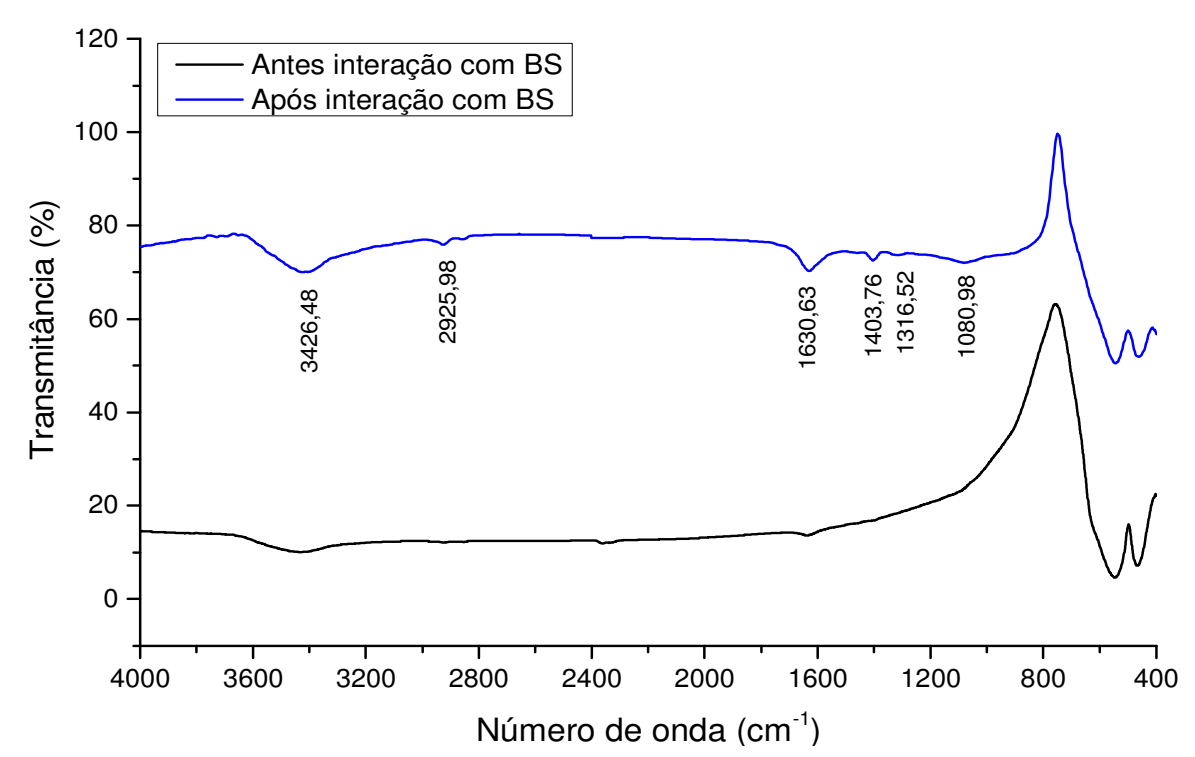

Figura 33. Espectro de FTIR de transmitância do mineral hematita (antes e após interação com o biossurfactante).

Portanto, baseando-se nas bandas e suas deslocações mostradas nos espectros FTIR, acontecem vários mecanismos de absorção do biossurfactante sobre a superfície mineral, assim como interações químicas entre os grupos funcionas e a superfície mineral.

Segundo Deo \& Natarajan (1997), as interações micróbio-minerais alteram a química de superfície quanto das células bacterianas como dos minerais. Assim sendo, eles observaram que a superfície de hematita apresentou os seguintes grupos: a banda $3400 \mathrm{~cm}^{-1}$ foi característica do estiramento $\mathrm{OH}$ e, grupos $\mathrm{C}-\mathrm{OH}$ e $\mathrm{CH}_{2} \mathrm{OH}$ devido a polissacarídeos; a banda $900 \mathrm{~cm}^{-1}$ para grupos $\mathrm{CH}_{2} \mathrm{OH}$; a banda $700 \mathrm{~cm}^{-1}$ devido à flexão do grupo carboxílico $\mathrm{COO}^{-}$e a banda entre $600-300 \mathrm{~cm}^{-1}$ foi atribuída às vibrações de balanço $\mathrm{CH}_{2}$.

Já no trabalho de Yang et al. (2013b) estudaram o espectro de FTIR do mineral hematita após interação com Rhodococcus erythropolis e, demonstraram 
que a adsorção das células bacterianas ocorreu, principalmente, através de adsorção química, incluindo interações químicas do grupo carboxílico e grupo fosfato com a superfície mineral. Além disso, foi observada uma associação hidrofóbica entre partículas hidrofobizadas.

\subsubsection{2.}

\section{Espectroscopia no infravermelho do mineral quartzo}

A Figura 34 e Figura 35, apresentam os espectrogramas de infravermelho para do mineral quartzo, antes e após interação com o biossurfactante, respectivamente. Antes da interação, a superfície de quartzo mostrou a banda de $3468,87 \mathrm{~cm}^{-1}$ corresponde à vibração de estiramento de $\mathrm{OH}$, que geralmente é atribuída a ligações de hidrogênio produzidas por $\mathrm{OH}$ ou água residual na superfície da amostra (Huang et al., 2014; Jiang et al., 2012; Liu et al., 2017; Mohammadnejad et al., 2013). A banda $1615,59 \mathrm{~cm}^{-1}$ é devido à vibração de flexão de OH (Liu et al., 2017). As bandas características variando de $1200 \mathrm{~cm}^{-1} \mathrm{a}$ $400 \mathrm{~cm}^{-1}$ são devido às ligações mais fortes de Si-O. Assim, a banda de 1083,71 $\mathrm{cm}^{-1}$ é atribuída à vibração de estiramento assimétrico de Si-O; a banda de 777,83 cm¹ 1 corresponde à vibração de estiramento simétrico de Si-O; a banda 689,33 $\mathrm{cm}^{-1}$ e $459,80 \mathrm{~cm}^{-1}$ são atribuídas à vibração de flexão simétrica de Si-O e vibração de flexão assimétrica de Si-O, respectivamente (Liu et al., 2015, 2017).

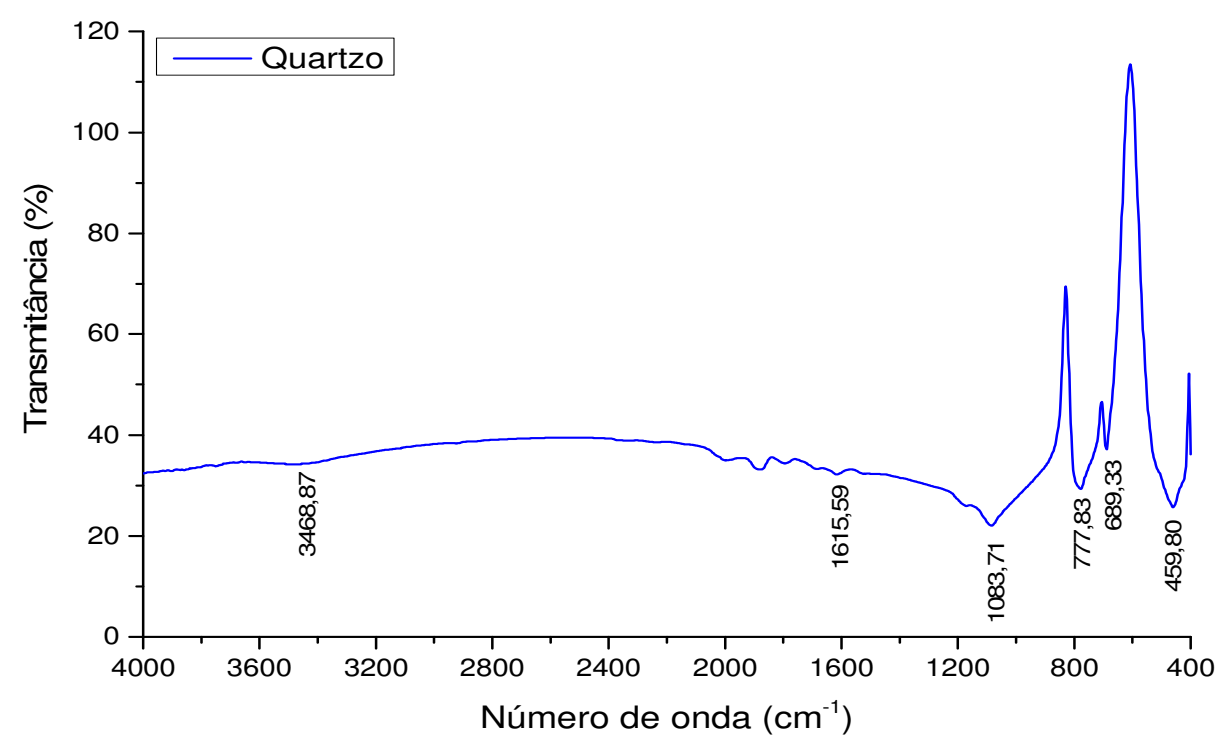

Figura 34. Espectro de FTIR de transmitância do mineral quartzo. 
Após interação se observaram duas principais bandas que indicariam que houve alguma absorção dos grupos funcionais do biossurfactante. Sendo assim, as vibrações de estiramento de grupos $\mathrm{OH}$ e $\mathrm{NH}$ mudaram de $3417,64 \mathrm{~cm}^{-1}$ para $3466,65 \mathrm{~cm}^{-1}$ e o estiramento $\mathrm{C}=\mathrm{O}$ da amida I na proteína mudou de $1634,34 \mathrm{~cm}^{-1}$ para $1621,00 \mathrm{~cm}^{-1}$.

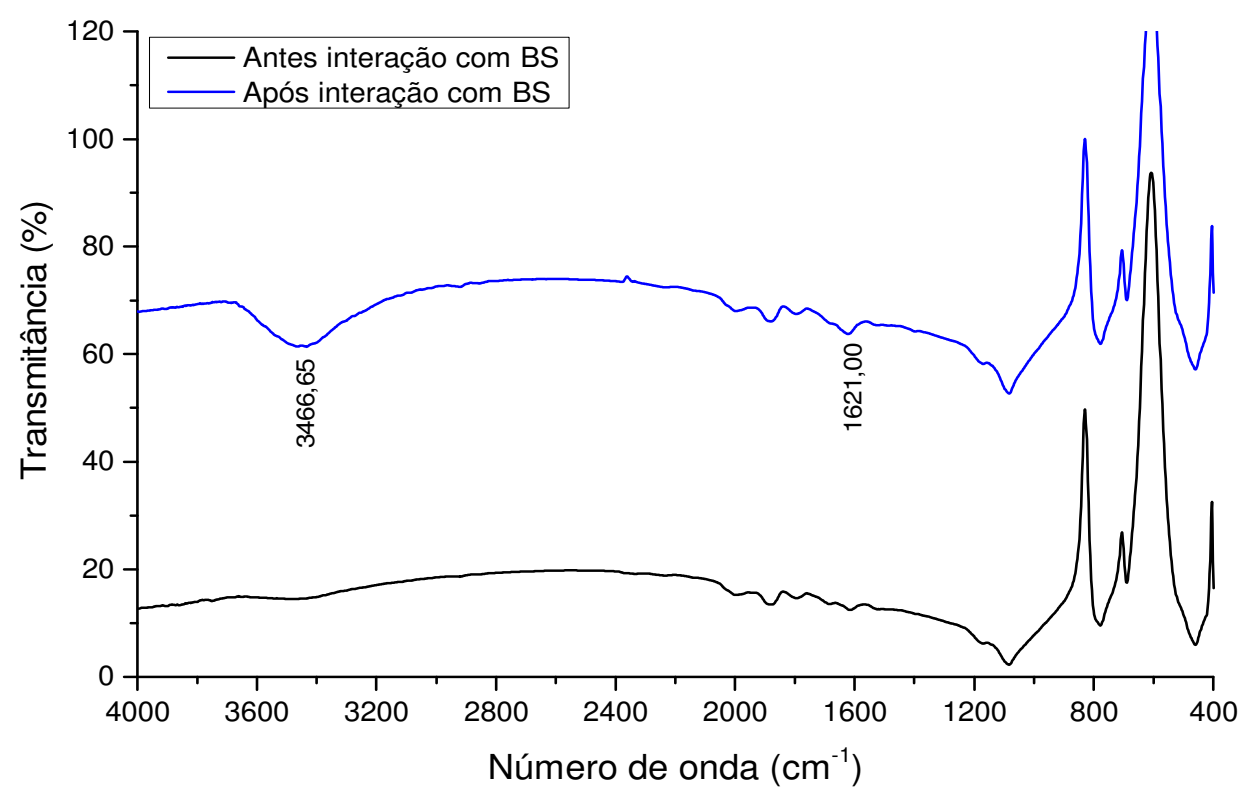

\section{Figura 35. Espectro de FTIR de transmitância do mineral quartzo (antes e} após interação com o biossurfactante).

Os resultados acima mostraram uma baixa adsorção do biossurfactante na superfície do quartzo em comparação da superfície de hematita. Esse efeito também foi observado no trabalho de Deo et al. (2001). As análises de FTIR após interação com a bactéria Paenibacillus polymyxa indicaram claramente a presença de ânion carboxilato e grupo C-OH de polissacarideos na superificie de hematita, enquanto na superficie de quartzo foram encontrados grupos amino de compostos proteináceos.

Outros autores como Liu et al. (2015) e Li et al. (2017) avaliaram a interação de quartzo com N-dodecil-etilenodiamina (ND) e coletor AY, respectivamente. No primeiro, os resultados de FTIR mostraram que as bandas de vibração de estiramento assimétrico $\mathrm{Si}$-O e vibração de estiramento simétrico de Si-O não foram alterados claramente após a adsorcão com ND, o qual revelou uma baixa adsorção física . Já com o coletor AY, os resultados de FTIR 
mostraram uma banda intensa de vibração de flexão de $\mathrm{N}-\mathrm{H}$, indicando que o colector foi adsorvido na superfície de quartzo.

\section{4.}

\section{Estudos de adsorção}

Os experimentos de adsorção estabelecem a afinidade que o biossurfactante tem pelas superfícies dos minerais. A afinidade pode-se apresentar pela interação entre os grupos funcionais presentes no biossurfactante e a superfície mineral (Sharma \& Hanumantha, 2002).

O tempo de contato, $\mathrm{pH}$ da solução e concentração do biossurfactante são fatores importantes para determinar a capacidade de adsorção. Dessa forma, a adsorção do biossurfactante às superfícies da hematita e do quartzo foi estudada em função do pH e da concentração.

\subsection{1. Adsorção do biossurfactante na superfície da hematita}

Na Figura 36, pode-se observar os resultados da adsorção do biossurfactante sobre a superfície da hematita, avaliando-se o efeito do $\mathrm{pH}$ da solução e da concentração do biossurfactante. Esses resultados mostram que em todas as concentrações utilizadas, a maior adsorção foi alcançada na faixa ácida, principalmente no $\mathrm{pH}$ 3. Observou-se também que quanto maior a concentração do biossurfactante, maior a capacidade de adsorção. Sendo assim, para concentrações do biossurfactante de 50 e $200 \mathrm{mg} / \mathrm{L}$, a quantidade máxima adsorvida foi de 4,15 e 11,62 mg de biossurfactante por grama de mineral, respectivamente. 


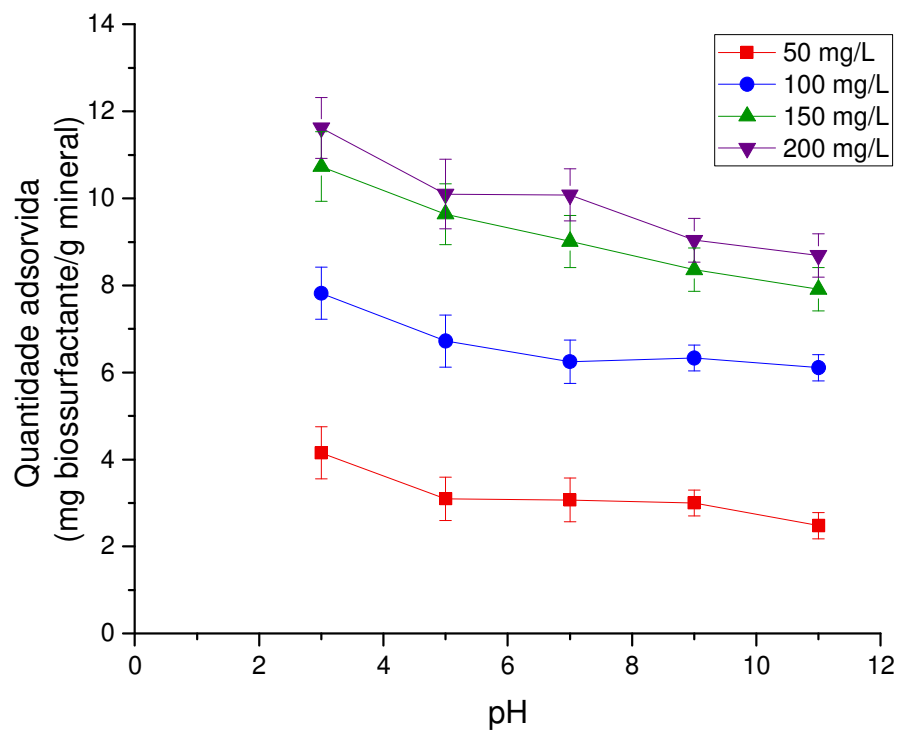

Figura 36. Influência do pH na adsorção do biossurfactante sobre a superfície da hematita.

Deo et al. (2001) descobriram uma alta adsorção celular de $P$. polymyxa sobre a superfície da hematita em $\mathrm{pH}$ baixo e uma acentuada diminuição da adsorção acima do pH 9. De acordo com os autores, esta alta adsorção está relacionada a forças eletrostáticas atrativas entre a superfície negativa das células e a superfície positiva da hematita, enquanto a diminuição da adsorção em valores de $\mathrm{pH}$ alto está relacionada com a repulsão eletrostática entre ambas as superfícies carregadas negativamente.

Lopez et al. (2015) utilizaram a biomassa de células de Rhodococcus ruber na flotação de hematita e estudaram sua capacidade de adesão na superfície do mineral. Os autores encontraram que a adesão de biomassa foi maior em torno do pH 3, usando uma concentração de $0,6 \mathrm{~g} / \mathrm{L}$ (ou $10^{9}$ células $/ \mathrm{mL}$ ).

Olivera et al. (2017) estudaram a adesão da biomassa de Rhodococcus erythropolis na superfície de hematita Os ensaios de adesão mostraram que a quantidade máxima de bactéria aderida na superfície mineral foi ao redor de 8,7 miligramas por grama de mineral, com uma concentração de solução de 200 $\mathrm{mg} / \mathrm{L}$. 


\subsection{2.}

\section{Adsorção do biossurfactante na superfície do quartzo}

A adsorção do biossurfactante sobre a superfície do quartzo foi também avaliada em função do $\mathrm{pH}$ da solução e da concentração do biossurfactante, conforme é mostrado na Figura 37. Os resultados mostram que em todas as concentrações utilizadas, a maior adsorção foi alcançada na faixa ácida, principalmente no $\mathrm{pH} 3$. Observou-se também que quanto maior a concentração do biossurfactante, maior a capacidade de adsorção. Sendo assim, para concentrações do biossurfactante de 50 e $200 \mathrm{mg} / \mathrm{L}$, a quantidade máxima adsorvida foi de 2,99 e 6,28 $\mathrm{mg}$ de biossurfactante por grama de mineral, respectivamente.

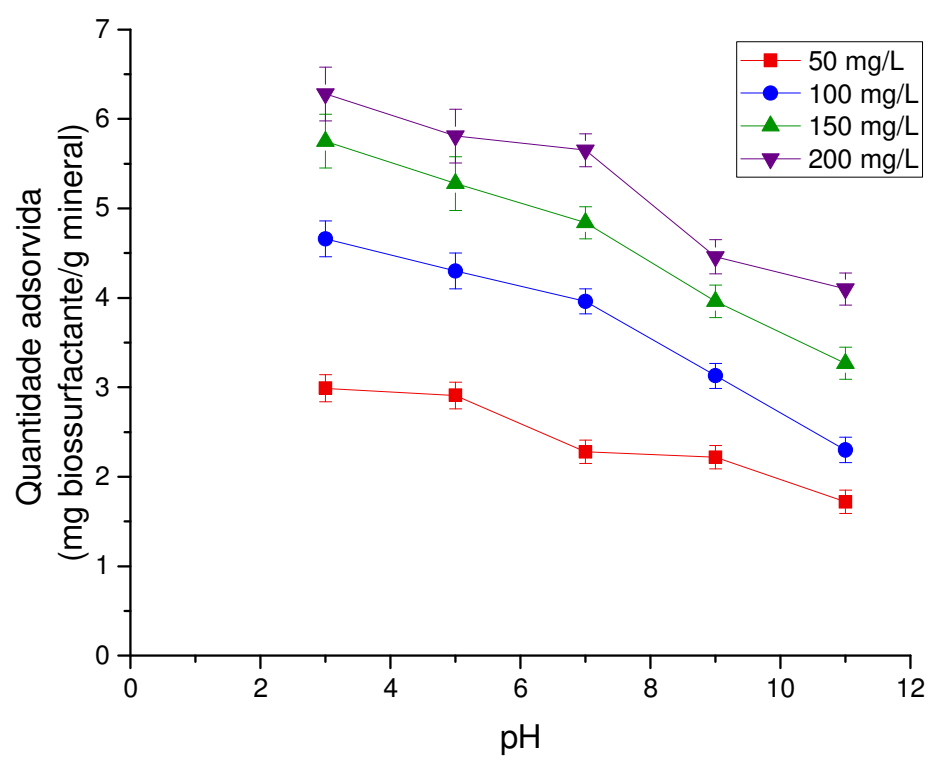

Figura 37. Influência do pH na adsorção do biossurfactante sobre a superfície do quartzo.

Mesquita et al. (2003) estudaram a adesão das células Rhodococcus opacus na superficie de quartzo, em funcão dos valores de pH. A maior adesão (18 mg células por grama de quartzo) foi alcançada no pH 3, com uma concentração de $600 \mathrm{mg} / \mathrm{L}$.

Farahat et al. (2008) avaliram o efeito do tempo de condicionamento, $\mathrm{pH}$ e concentração celular na adsorção de SIP E. coli em quartzo. Os ensaios mostrarm maior adsorção de células na faixa acida $(\mathrm{pH}<4,5)$, onde o quartzo e a SIP E. coli 
têm cargas de superfície diferentes e, consequentemente, estão altamente sujeitos a interação eletrostática. A valores de $\mathrm{pH}$ superiores ao $\mathrm{PIE}(\mathrm{pH}=4,5)$ de E. coli, o número de células adsorvidas diminuiu ao fato de que as partículas de quartzo e as bactérias têm a mesma carga superficial, levando a forças de repulsão entre elas, o que provavelmente dificulta o processo de adsorção.

Sabari \& Natarajan (2010) estudaram a cinética de adsorção das proteínas e polissacarídeos extracelulares extraídos da bactéria Desulfovibrio desulfuricans. Esses estudos indicaram que as superfícies de quartzo exibiram a maior adsorção de proteínas extracelulares, enquanto as superfícies de hematita exibiram a maior adsorção de polissacarídeos extracelulares.

\section{5.}

\section{Ensaios de microflotação}

Foram realizados diferentes ensaios de microflotação de hematita e de quartzo com biossurfactante. Neste estudo avaliou-se o efeito do $\mathrm{pH}$, a concentração do biossurfactante e o tempo para determinar a cinética de flotação. Além disso, foram realizados ensaios de flotabilidade do sistema hematita-quartzo para avaliar o efeito da concentração de silicato de sódio.

\subsection{1. \\ Arraste mecânico}

No processo de flotação em espuma, a ligação de partículas minerais de interesse às bolhas de ar é o mecanismo mais importante e representa a maioria das partículas que são recuperadas para o concentrado. Embora a flotação verdadeira seja o mecanismo dominante para a recuperação de minerais de interesse, a eficiência de separação entre o mineral de interesse e a ganga também dependem do grau de arrastamento e do aprisionamento físico (Wills \& Finch, 2015). Sendo assim, o fenômeno de arraste (entrainment e entrapment) pode transportar partículas independentemente do seu caráter hidrofóbico ou hidrofílico prejudicando a seletividade do processo (Hacha, 2016).

A Figura 38 apresenta os valores de arraste mecânico da hematita e quartzo, em função do $\mathrm{pH}$. Os resultados mostram que o $\mathrm{pH}$ da solução tem pouca influência no arraste das partículas minerais, cujos valores de arraste máximo para 
a hematita e o quartzo foram de $3 \%$ e $1 \%$, respectivamente. Esse arraste encontrado pode ser atribuído a diferentes fatores, tais como: distribuição granulométrica, densidade mineral, propriedades reológicas da solução, estrutura da espuma, vazão de ar e condições hidrodinâmicas da célula (Hacha, 2016).

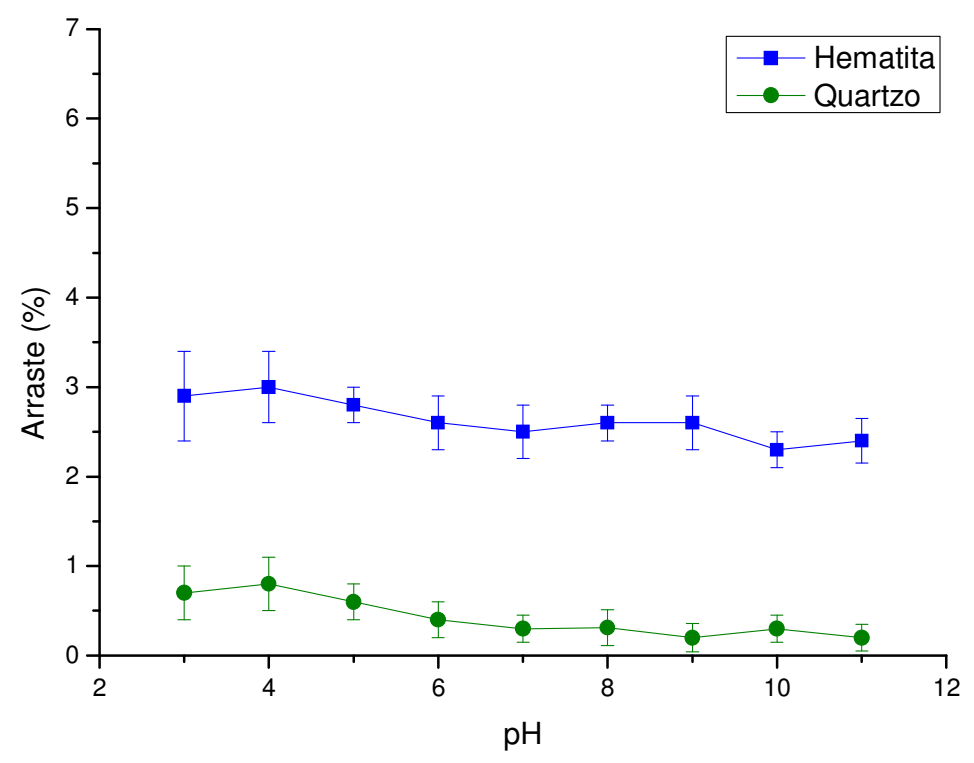

Figura 38. Arraste mecânico da hematita e quartzo, em função do pH.

\subsection{2. \\ Microflotação de hematita}

\subsubsection{1.}

\section{Efeito do pH na microflotação de hematita}

Sabe-se que a variável mais importante no processo de flotação é o pH da solução. Esta variável influencia nas propriedades de superfície do mineral, por exemplo, a carga superficial é determinada pelo $\mathrm{pH}$ do meio de acordo com a concentração relativa de $\mathrm{H}^{+}$e $\mathrm{OH}^{-}$em solução (Hacha, 2016; Quast, 2015). Além disso, as propriedades superficiais dos microrganismos são afetadas também pelo $\mathrm{pH}$ do sistema, grupos funcionais presentes na sua parede celular e/ou metabolitos podem ser ativadas ou inibidas influenciando na interação mineral-biorreagente (Kim et al., 2015; Hacha, 2016; Sanwani et al., 2016).

A Figura 39 apresenta a flotabilidade da hematita em função do $\mathrm{pH}$ com uma concentração do biossurfactante de $10 \mathrm{mg} / \mathrm{L}$. Nessas condições, a maior flotabilidade $(88,16 \%)$ foi alcançada na faixa de $\mathrm{pH}$ ácido, principalmente no $\mathrm{pH}$ 
3. Já para valores de pH acima de 3, a flotabilidade de hematita foi diminuindo conforme o meio fica mais alcalino. Segundo os resultados obtidos, o pH ótimo para a flotabilidade de hematita se encontra no $\mathrm{pH} 3$. Esse efeito foi confirmado pelos resultados de medições de ângulo de contato e experimentos de adsorção onde os melhores valores de hidrofobicidade e adsorção, respectivamente, foram alcançados principalmente no valor de pH 3. Nesse pH, a interação hematitabiossurfactante se mostrou forte. Tal comportamento foi confirmado pelos estudos de potencial zeta, mostrando que houve grande mudança no perfil de potencial zeta da hematita após interação com o biossurfactante, provocando o deslocamento do PIE do mineral de um pH 5,2 até aproximadamente 4,4. Além disso, a alta flotabilidade no valor de $\mathrm{pH} 3$, pode ser atribuído aos diferentes grupos funcionais com caráter hidrofóbico presentes no biossurfactante que se mostram muito ativos e favorecem a adsorção do biossurfactante nas partículas minerais de hematita e, consequentemente aumentam a flotabilidade da hematita.

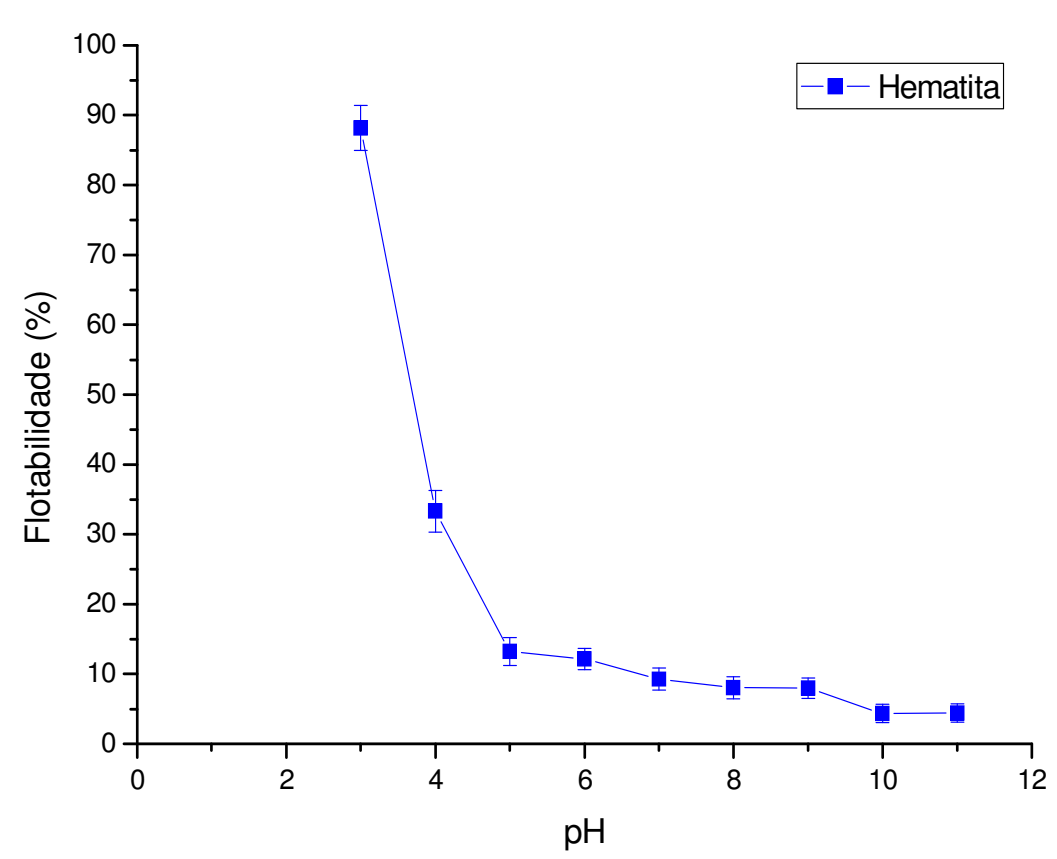

Figura 39. Efeito do pH na microflotação de hematita. Concentração do biossurfactante: $10 \mathrm{mg} / \mathrm{L}$.

Yang et al. (2013b) estudaram a flotabilidade de hematita usando o Rhodococcus erythropolis. Os autores observaram que a maior recuperação foi alcançada em meio ácido, sendo ótima ao redor do pH 6. Similarmente, aconteceu 
no trabalho de Olivera et al. (2017). A maior flotabilidade de hematita foi encontrado no valor de pH 6 e sua recuperação máxima foi de 84\%, com concentração de R. erythropolis de $200 \mathrm{mg} / \mathrm{L}$.

\subsubsection{2. \\ Efeito da concentração do biossurfactante na microflotação de hematita}

O efeito da concentração do biossurfactante na flotabilidade de hematita é apresentado na Figura 40. O estudo foi realizado em pH 3, com concentração do biossurfactante de 10 até $150 \mathrm{mg} / \mathrm{L}$. Segundo os resultados obtidos observa-se valores de flotabilidade máxima de 99,88 \% para uma concentração de 100 mg/L. Já para concentrações maiores que $100 \mathrm{mg} / \mathrm{L}$, a flotabilidade de hematita tem uma pequena diminuição que pode ser atribuída ao valor da concentração micelar crítica (CMC) do biossurfactante ( 100 mg/L), onde tem-se a saturação do meio e as moléculas residuais do biossurfactante passam a formar micelas.

Segundo Yang et al. (2007), a diminuição da flotabilidade pode estar ligada à formação de flocos. Flocos muito grandes excedem a capacidade de carregamento da bolha, resultando na diminuição da recuperação. Para Ekmekyapar et al. (2006), a formação de agregados durante a adsorção do biorreagente na superficie do mineral causa diminuição da área efetiva de adsorção e, consequentemente, perjudica a flotabilidade do mineral. 


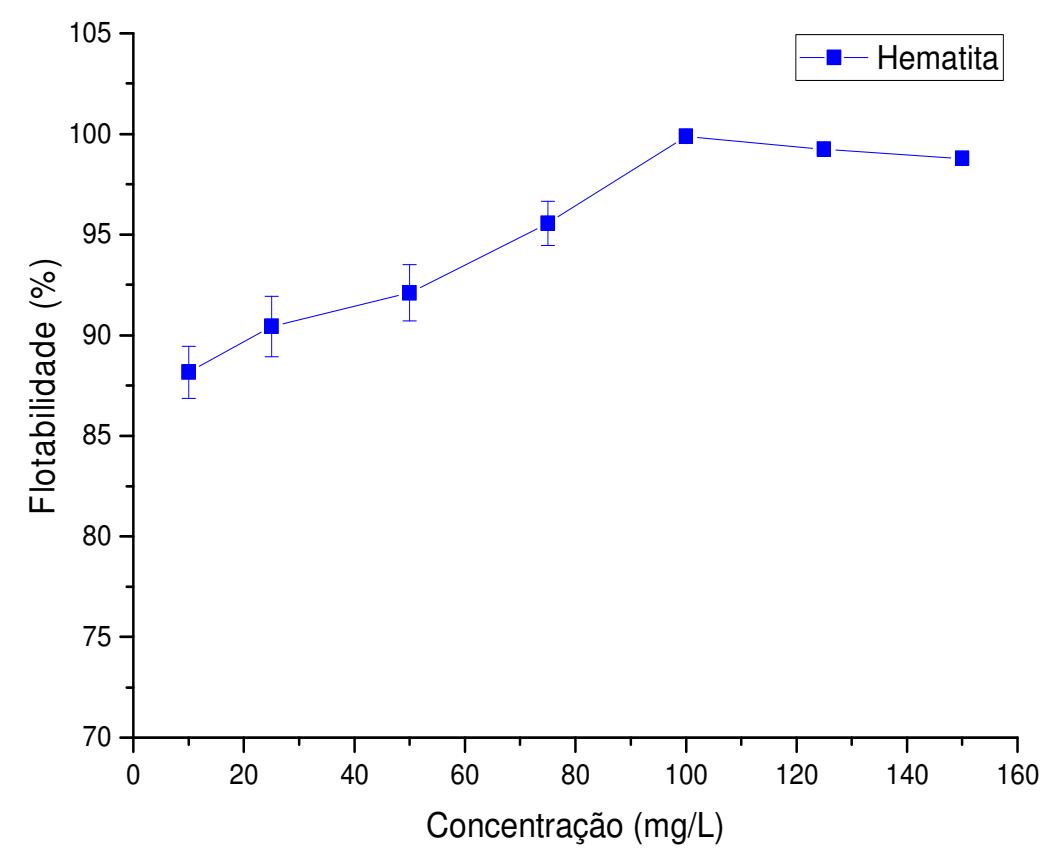

Figura 40. Efeito da concentração do biossurfactante na microflotação de hematita. pH: 3 .

Yang et al. (2013b) alcançaram a flotabilidade máxima de hematita com concentração de $R$. erythropolis de $100 \mathrm{mg} / \mathrm{L}$. Já no trabalho de Olivera et al. (2017), o valor foi ao redor de $200 \mathrm{mg} / \mathrm{L}$, usando a bactéria $R$. erythropolis como biorreagente.

\subsubsection{3.}

Modelo de regressão polinomial da microflotação de hematita

$\mathrm{Na}$ Tabela 13 se indicam os valores de flotabilidade da hematita (\%) obtidos nos diferentes ensaios de microflotação realizados. Esses dados experimentais foram utilizados para o ajuste do modelo de regressão polinomial que incorpora os efeitos individuais das variáveis, assim como a interação entre as mesmas. 
Tabela 13. Flotabilidade (\%) da hematita nos ensaios de microflotação utilizando o biossurfactante solúvel produzido por Rhodococcus erythropolis

\begin{tabular}{|c|c|c|c|}
\hline $\begin{array}{l}\text { Número do } \\
\text { experimento }\end{array}$ & $\begin{array}{l}\text { Concentração } \\
\text { do BS }(\mathrm{mg} / \mathrm{L})\end{array}$ & pH & $\begin{array}{c}\text { Flotabilidade } \\
(\%)\end{array}$ \\
\hline 1 & 0 & 3 & 2,90 \\
\hline 2 & 25 & 3 & 87,09 \\
\hline 3 & 50 & 3 & 94,87 \\
\hline 4 & 75 & 3 & 98,56 \\
\hline 5 & 100 & 3 & 99,87 \\
\hline 6 & 125 & 3 & 97,47 \\
\hline 7 & 150 & 3 & 98,97 \\
\hline 8 & 0 & 5 & 2,80 \\
\hline 9 & 25 & 5 & 26,89 \\
\hline 10 & 50 & 5 & 69,67 \\
\hline 11 & 75 & 5 & 75,13 \\
\hline 12 & 100 & 5 & 85,15 \\
\hline 13 & 125 & 5 & 84,78 \\
\hline 14 & 150 & 5 & 84,11 \\
\hline 15 & 0 & 7 & 2,50 \\
\hline 16 & 25 & 7 & 17,80 \\
\hline 17 & 50 & 7 & 20,56 \\
\hline 18 & 75 & 7 & 25,65 \\
\hline 19 & 100 & 7 & 28,79 \\
\hline 20 & 125 & 7 & 23,94 \\
\hline 21 & 150 & 7 & 24,65 \\
\hline 22 & 0 & 9 & 2,60 \\
\hline 23 & 25 & 9 & 12,35 \\
\hline 24 & 50 & 9 & 14,56 \\
\hline 25 & 75 & 9 & 15,87 \\
\hline 26 & 100 & 9 & 14,27 \\
\hline 27 & 125 & 9 & 16,58 \\
\hline 28 & 150 & 9 & 12,21 \\
\hline 29 & 0 & 11 & 2,40 \\
\hline 30 & 25 & 11 & 7,89 \\
\hline 31 & 50 & 11 & 9,67 \\
\hline 32 & 75 & 11 & 12,51 \\
\hline 33 & 100 & 11 & 11,78 \\
\hline 34 & 125 & 11 & 10,24 \\
\hline 35 & 150 & 11 & 9,87 \\
\hline
\end{tabular}

A análise de regressão foi estudada em relação de uma variável dependente (flotabilidade) com outras duas variáveis independentes (concentração do 
biossurfactante e $\mathrm{pH}$ ), visando determinar uma função matemática que busca descrever o comportamento da flotabilidade.

$\mathrm{O}$ efeito da concentração do biossurfactante e do $\mathrm{pH}$ da solução foi analisado com base nos critérios de valor-p, considerando-se satisfatório o limite de 5\% de probabilidade de erro, não sendo significativas as diferenças que tiverem uma probabilidade acima desse limite. A Tabela 14 mostra os coeficientes estimados do modelo de regressão polinomial, onde $x_{1}$ é o $\mathrm{pH}$ da solução e $x_{2}$ é a concentração do biossurfactante, com seu respectivo valor-p.

Tabela 14. Coeficientes do modelo de regressão polinomial da microflotação de hematita.

\begin{tabular}{c|c|c}
\hline Coeficientes & Estimação & valor-p \\
\hline Intercepto & -254.13 & 0.032331 \\
\hline$x_{1}$ & 203.75 & 0.013709 \\
\hline$x_{2}$ & 3.603 & 0.00096172 \\
\hline$x_{1}{ }^{2}$ & -53.959 & 0.0069367 \\
\hline$x_{1} \cdot x_{2}$ & 0.057187 & 0.86541 \\
\hline$x_{2}{ }^{2}$ & -0.047844 & $9.2693 E-05$ \\
\hline$x_{1}{ }^{3}$ & 5.7515 & 0.0043005 \\
\hline$x_{1}{ }^{2} \cdot x_{2}$ & -0.10018 & 0.029721 \\
\hline$x_{1} \cdot x_{2}^{2}$ & 0.0062133 & 0.0019778 \\
\hline$x_{2}{ }^{3}$ & 0.00013689 & 0.0027323 \\
\hline$x_{1}{ }^{2}$ & -0.21243 & 0.0032146 \\
\hline$x_{1}{ }^{3} \cdot x_{2}$ & 0.0058929 & 0.0060738 \\
\hline$x_{1}{ }^{2} \cdot x_{2}{ }^{2}$ & -0.00014082 & 0.13459 \\
\hline$x_{1} \cdot x_{2}{ }^{3}$ & $-1.4222 E-05$ & 0.014562 \\
\hline & & \\
\hline & & \\
\hline
\end{tabular}

O modelo de regressão polinomial ajustado é uma função de $4^{\mathrm{a}}$ ordem para o pH da solução e de $3^{\mathrm{a}}$ ordem para a concentração do biossurfactante, com um coeficiente de correlação $\left(\mathrm{R}^{2}\right)$ igual a 95,46\%. A Equação 7 mostra a função polinomial da microflotação de hematita, considerando o limite de probabilidade estabelecido: 


$$
\begin{aligned}
& R=p_{00}+p_{10} x_{1}+p_{01} x_{2}+p_{20} x_{1}^{2}+p_{02} x_{2}^{2}+p_{30} x_{1}^{3}+p_{21} x_{1}^{2} \cdot x_{2}+p_{12} x_{1} \cdot x_{2}^{2}+p_{03} \\
& x_{2}^{3}+p_{40} x_{1}^{4}+p_{31} x_{1}^{3} \cdot x_{2}+p_{13} x_{1} \cdot x_{2}^{3}
\end{aligned}
$$

A superfície de resposta do processo de microflotação de hematita é apresentada na Figura 41-a e as diferentes zonas do processo de microflotação são apresentadas no gráfico de contornos (Figura 41-b). A partir do mesmo, pode-se apreciar que a melhor zona de microflotação de hematita é na faixa ácida de $\mathrm{pH}$ usando entre 50 a $150 \mathrm{mg} / \mathrm{L}$ do biossurfactante. Esses resultados evidenciam os mesmos efeitos tanto do $\mathrm{pH}$ da solução como da concentração do biossurfactante que já foram estudados nas seções 4.5.2.1 e 4.5.2.2, respectivamente.
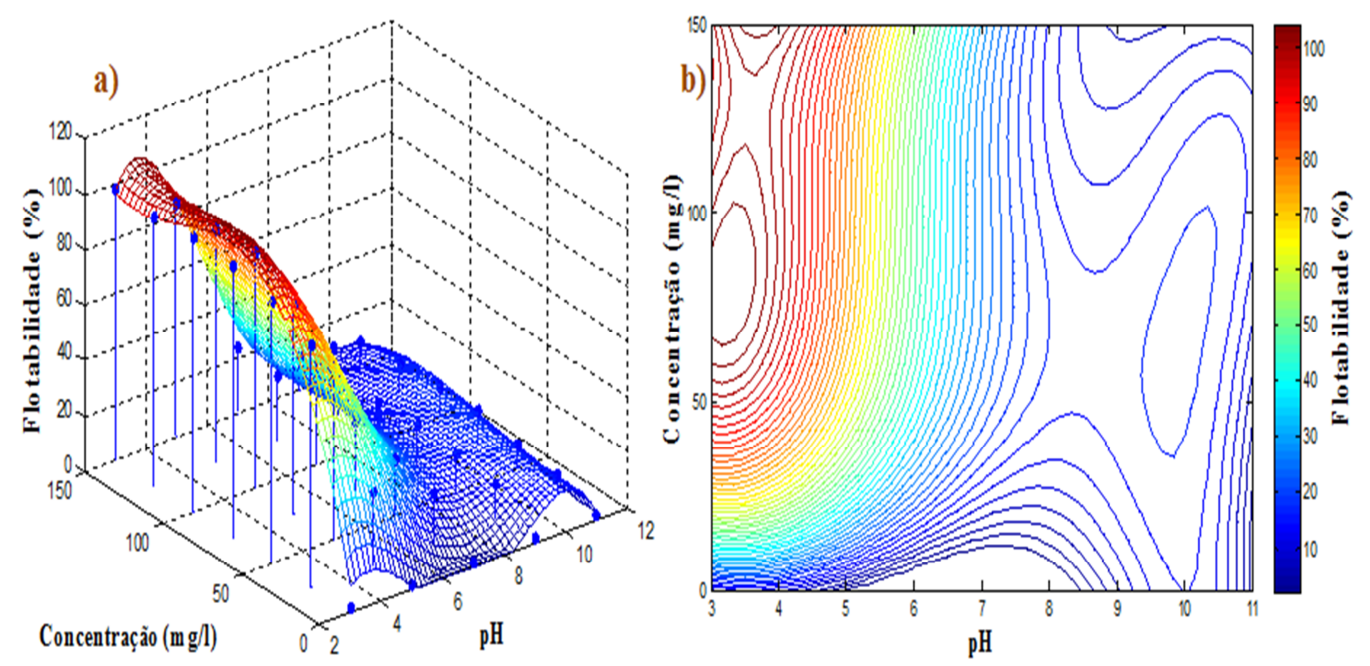

Figura 41. a) Superfície de resposta 3D da microflotação de hematita em função da concentração do biossurfactante e do pH da solução; b) Gráfico de contorno 3D da microflotação de hematita em função da concentração do biossurfactante e do pH da solução.

\subsection{3.}

\section{Microflotação de quartzo}

\subsubsection{1.}

\section{Efeito do pH na microflotação de quartzo}

A Figura 42 apresenta a flotabilidade de quartzo em função do pH com uma concentração do biossurfactante de $10 \mathrm{mg} / \mathrm{L}$. Nessas condições, a maior 
flotabilidade de 10,28\% foi alcançada no $\mathrm{pH}$ 3. Já para valores de $\mathrm{pH}$ acima de 3, a flotabilidade de quartzo foi diminuindo conforme o meio fica mais alcalino. Segundo os resultados obtidos, o pH ótimo para a flotabilidade de quartzo se encontra no $\mathrm{pH}$ 3. Esse efeito foi confirmado tanto pelos resultados de medições de ângulo de contato como os experimentos de adsorção, onde os melhores valores de hidrofobicidade e adsorção, respectivamente, foram alcançados ao redor do pH 3. Nesse pH, existiu maior interação entre as partículas de quartzo e o biossurfactante. Tal comportamento foi confirmado pelos estudos de potencial zeta, mostrando que houve mudança no perfil de potencial zeta do quartzo após interação com o biossurfactante, provocando o deslocamento do PIE do mineral de um $\mathrm{pH}$ 1,9 para 4,4. Além disso, a alta flotabilidade no valor de $\mathrm{pH} 3$, pode ser atribuído aos diferentes grupos funcionais com caráter hidrofóbico presentes no biossurfactante que se mostram muito ativos e favorecem a adsorção do biossurfactante nas partículas minerais de quartzo e, consequentemente aumentam a flotabilidade do quartzo.

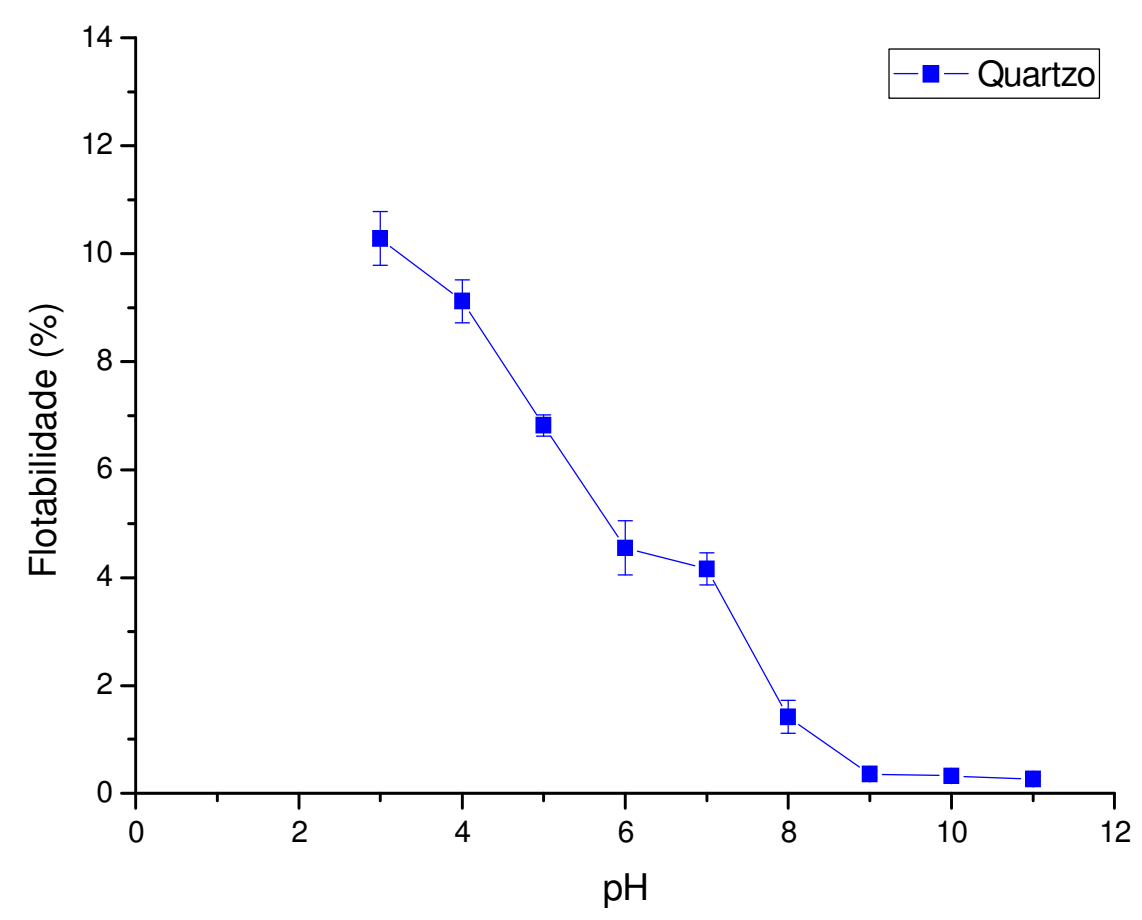

Figura 42. Efeito do pH na microflotação de quartzo. Concentração do biossurfactante: $10 \mathrm{mg} / \mathrm{L}$. 
Diferente autores estudaram a flotabilidade de quartzo usando microrganismos como biorreagentes, por exemplo, Merma et al. (2013) realizaram estudos de flotabilidade de quartzo usando o Rhodococcus opacus. Os autores observaram que a melhor flotabilidade de quartzo foi alcançada ao redor do $\mathrm{pH} 5$. Já no trabalho de (Yang et al., 2013a), a maior flotabilidade de quartzo foi encontrado no valor de $\mathrm{pH} 6$.

\subsubsection{2. Efeito da concentração do biossurfactante na microflotação de quartzo}

A Figura 43 apresenta o efeito da concentração do biossurfactante na flotabilidade de quartzo. $\mathrm{O}$ estudo foi realizado em $\mathrm{pH} 3$, com concentração do biossurfactante de 10 até $150 \mathrm{mg} / \mathrm{L}$. Segundo os resultados obtidos, observa-se que os maiores valores de flotabilidade foram alcançados em concentrações de 75 e $100 \mathrm{mg} / \mathrm{L}$ com recuperações de $25,75 \%$ e $31,05 \%$, respectivamente. Já para concentrações maiores que $100 \mathrm{mg} / \mathrm{L}$, a flotabilidade de quartzo começa a diminuir.

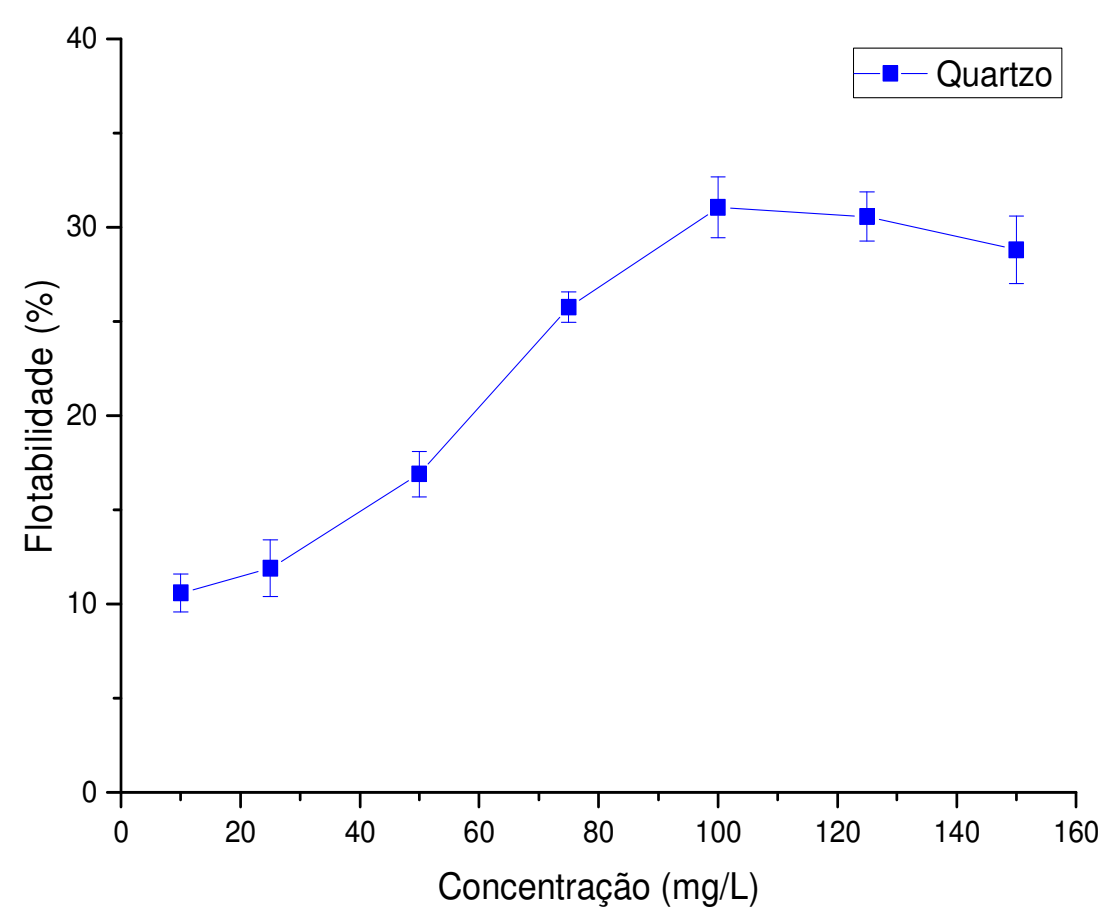

Figura 43. Efeito da concentração do biossurfactante na microflotação de quartzo. pH: 3. 
Em outros trabalhos foram encontrados diferentes valores de concentração maxima de biorreagente na flotação de quartzo. Mesquita et al. (2003) alcançaram a flotabilidade máxima de quartzo com concentração de $R$. erythropolis de 600mg/L. Para Merma et al. (2013), o valor foi ao redor de $150 \mathrm{mg} / \mathrm{L}$, usando a bactéria $R$. opacus como biorreagente. Já no trabalho de Yang et al. (2013b) alcançaram a flotabilidade máxima de quartzo com concentração de $R$. erythropolis de $60 \mathrm{mg} / \mathrm{L}$.

\subsubsection{3.}

Modelo de regressão polinomial da microflotação de quartzo

O modelo de regressão polinomial da microflotação de quartzo foi obtido a partir dos valores de flotabilidade (\%) em função da concentração do biossurfactante e do pH da solução, tal como indicados na Tabela 15. 
Tabela 15. Flotabilidade (\%) do quartzo nos ensaios de microflotação utilizando o biossurfactante solúvel produzido por Rhodococcus erythropolis

\begin{tabular}{|c|c|c|c|}
\hline $\begin{array}{l}\text { Número do } \\
\text { experimento }\end{array}$ & $\begin{array}{l}\text { Concentração } \\
\text { do BS (mg/L) }\end{array}$ & pH & $\begin{array}{c}\text { Flotabilidade } \\
(\%)\end{array}$ \\
\hline 1 & 0 & 3 & 0,70 \\
\hline 2 & 25 & 3 & 11,89 \\
\hline 3 & 50 & 3 & 16,89 \\
\hline 4 & 75 & 3 & 25,75 \\
\hline 5 & 100 & 3 & 31,05 \\
\hline 6 & 125 & 3 & 30,56 \\
\hline 7 & 150 & 3 & 28,79 \\
\hline 8 & 0 & 5 & 0,60 \\
\hline 9 & 25 & 5 & 6,01 \\
\hline 10 & 50 & 5 & 10,20 \\
\hline 11 & 75 & 5 & 11,13 \\
\hline 12 & 100 & 5 & 12,01 \\
\hline 13 & 125 & 5 & 10,97 \\
\hline 14 & 150 & 5 & 10,86 \\
\hline 15 & 0 & 7 & 0,30 \\
\hline 16 & 25 & 7 & 2,21 \\
\hline 17 & 50 & 7 & 3,21 \\
\hline 18 & 75 & 7 & 3,15 \\
\hline 19 & 100 & 7 & 4,24 \\
\hline 20 & 125 & 7 & 4,17 \\
\hline 21 & 150 & 7 & 3,98 \\
\hline 22 & 0 & 9 & 0,20 \\
\hline 23 & 25 & 9 & 2,12 \\
\hline 24 & 50 & 9 & 2,89 \\
\hline 25 & 75 & 9 & 2,97 \\
\hline 26 & 100 & 9 & 3,89 \\
\hline 27 & 125 & 9 & 3,79 \\
\hline 28 & 150 & 9 & 3,28 \\
\hline 29 & 0 & 11 & 0,20 \\
\hline 30 & 25 & 11 & 2,12 \\
\hline 31 & 50 & 11 & 2,45 \\
\hline 32 & 75 & 11 & 2,78 \\
\hline 33 & 100 & 11 & 3,21 \\
\hline 34 & 125 & 11 & 2,89 \\
\hline 35 & 150 & 11 & 2,99 \\
\hline
\end{tabular}


$\mathrm{O}$ efeito da concentração do biossurfactante e do $\mathrm{pH}$ da solução foi analisado com base nos mesmos critérios de valor-p, considerando-se satisfatório o limite de $5 \%$ de probabilidade de erro. A Tabela 16 mostra os coeficientes estimados da regressão polinomial, onde $x_{1}$ é o $\mathrm{pH}$ da solução e $x_{2}$ é a concentração do biossurfactante, com seu respectivo valor-p.

Tabela 16. Coeficientes do modelo de regressão polinomial da microflotação de quartzo.

\begin{tabular}{c|c|c}
\hline Coeficientes & Estimação & valor-p \\
\hline Intercepto & -23.065 & 0.11975 \\
\hline$x_{1}$ & 15.189 & 0.13286 \\
\hline$x_{2}$ & 1.2443 & $4.7182 E-09$ \\
\hline$x_{1}{ }^{2}$ & -3.3921 & 0.15716 \\
\hline$x_{1} \cdot x_{2}$ & -0.35068 & $7.6449 E-08$ \\
\hline$x_{2}{ }^{2}$ & -0.0036559 & 0.076064 \\
\hline$x_{1}{ }^{3}$ & 0.31473 & 0.18642 \\
\hline$x_{1}{ }^{2} \cdot x_{2}$ & 0.034758 & $3.596 E-06$ \\
\hline$x_{1} \cdot x_{2}{ }^{2}$ & 0.00058762 & 0.016773 \\
\hline$x_{2}{ }^{3}$ & $5.9556 E-06$ & 0.72731 \\
\hline$x_{1}{ }^{4}$ & -0.010417 & 0.21729 \\
\hline$x_{1}{ }^{3} \cdot x_{2}$ & -0.0011012 & 0.00024357 \\
\hline$x_{1}{ }^{2} \cdot x_{2}{ }^{2}$ & $-4.2177 E-05$ & 0.001623 \\
\hline$x_{1} \cdot x_{2}{ }^{3}$ & $9.7778 E-07$ & 0.16809 \\
\hline$x_{2}{ }^{4}$ & $-4.2667 E-08$ & 0.43397 \\
\hline & & \\
\hline & & \\
\hline & & \\
\hline & & \\
\hline & & \\
\hline
\end{tabular}

O modelo de regressão polinomial ajustado é uma função de $4^{\mathrm{a}}$ ordem para o pH da solução e de $4^{\mathrm{a}}$ ordem para a concentração do biossurfactante, com um coeficiente de correlação $\left(\mathrm{R}^{2}\right)$ igual a 98,73\%. A Equação 7 mostra a função polinomial da microflotação de quartzo:

$R=p_{01} x_{2}+p_{11} x_{1} \cdot x_{2}+p_{21} x_{1}^{2} \cdot x_{2}+p_{12} x_{1} \cdot x_{2}^{2}+p_{31} x_{1}^{3} \cdot x_{2}+p_{22} x_{1}^{2} \cdot x_{2}^{2}$ 
A superfície de resposta do processo de microflotação de quartzo é apresentada na Figura 44-a e as diferentes zonas do processo de microflotação são apresentadas no gráfico de contornos (Figura 44-b). A partir do mesmo, pode-se observar que a melhor zona de microflotação de quartzo é em torno do pH 3, usando entre 100 a $150 \mathrm{mg} / \mathrm{L}$ do biossurfactante. Portanto, esses resultados estão de acordo com os encontrados na flotabilidade em função da concentração do biossurfactante e do pH da solução que já foram estudados nas seções 4.5.3.1 e 4.5.3.2, respectivamente.
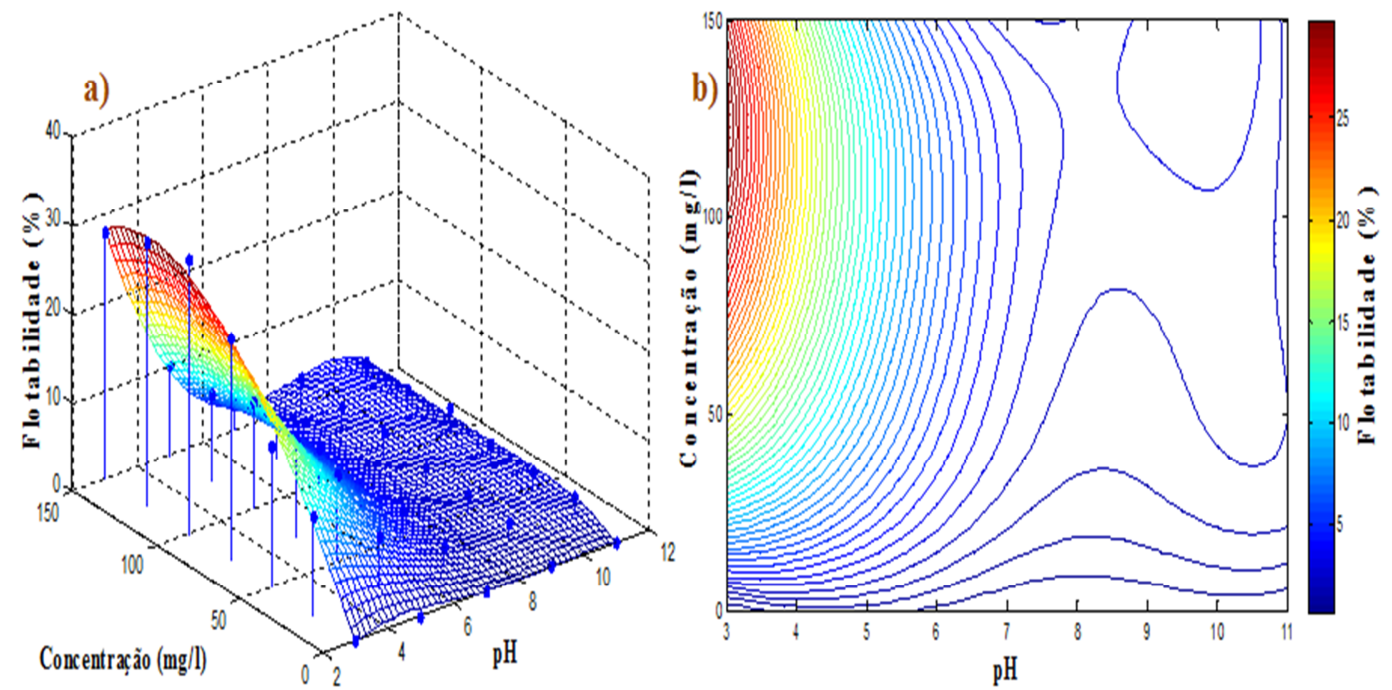

Figura 44. a) Superfície de resposta 3D da microflotação de quartzo em função da concentração do biossurfactante e do pH da solução; b) Gráfico de contorno 3D da microflotação de quartzo em função da concentração do biossurfactante e do pH da solução.

\subsection{4.}

Microflotação do sistema hematita-quartzo

Os ensaios de microflotação do sistema hematita-quartzo foram conduzidos objetivando-se estudar a seletividade do biossurfactante na flotação de hematita. Para isso, utilizou-se concentrações do biossurfactante de 50 e $100 \mathrm{mg} / \mathrm{L}$ e, metassilicato de sódio como reagente depressor de quartzo. 


\subsubsection{1. \\ Microflotação do sistema hematita-quartzo com diferentes relações de mistura}

Os ensaios de microflotação quanto da hematita como de quartzo (item 4.5.2 e 4.5.3) mostraram que a flotabilidade dos minerais foi maior no $\mathrm{pH}$ 3. Sendo assim, todos os ensaios de microflotação do sistema hematita-quartzo com diferentes relações de mistura foram realizados no $\mathrm{pH}$ ótimo de flotação $(\mathrm{pH}=3)$, conforme é mostrado na Tabela 17. Os resultados mostram que os teores de ferro total na massa flotada com concentrações de $50 \mathrm{mg} / \mathrm{L}$ e $100 \mathrm{mg} / \mathrm{L}$ do biossurfactante para cada relação de mistura foram muito próximos. Tal efeito é atribuído à boa eficiência do biorreagente em ambas as concentrações e, consequentemente boa flotabilidade.

Tabela 17. Microflotação do sistema hematita-quartzo em diferentes relações de mistura.

\begin{tabular}{c|c|c|c|c|c|c|c|c}
\hline \multirow{2}{*}{$\mathbf{p H}$} & \multirow{2}{*}{$\begin{array}{c}\text { BS } \\
(\mathbf{m g} / \mathbf{L})\end{array}$} & $\begin{array}{c}\text { H-Q } \\
(\%)\end{array}$ & \multirow{2}{*}{$\begin{array}{c}\text { Flotado } \\
(\%)\end{array}$} & \multirow{2}{*}{$\begin{array}{c}\text { FeT } \\
(\%)\end{array}$} & $\begin{array}{c}\text { Teores dos minerais } \\
(\%)\end{array}$ & \multicolumn{2}{|c}{ Recuperação (\%) } \\
\cline { 6 - 9 } & & & & Hematita & Quartzo & Hematita & Quartzo \\
\hline 3 & 50 & $25-75$ & 32,40 & 38,85 & 57,97 & 42,03 & 18,78 & 13,62 \\
\hline 3 & 100 & $25-75$ & 37,58 & 39,55 & 59,01 & 40,99 & 22,18 & 15,40 \\
\hline 3 & 50 & $50-50$ & 52,61 & 58,53 & 87,33 & 12,67 & 45,95 & 6,66 \\
\hline 3 & 100 & $50-50$ & 56,62 & 59,86 & 89,32 & 10,68 & 50,57 & 6,05 \\
\hline 3 & 50 & $75-25$ & 69,87 & 62,77 & 93,66 & 6,34 & 65,44 & 4,43 \\
\hline 3 & 100 & $75-25$ & 71,82 & 63,88 & 95,31 & 4,69 & 68,46 & 3,36 \\
\hline
\end{tabular}

Onde:

H-Q: mistura hematita-quartzo e FeT: teor de ferro total no flotado.

A Tabela 17 mostrou também que a recuperação de hematita foi favorável em todas as relações de mistura, sendo maior quando sua proporção aumenta e quando a concentração do biossurfactante atinge a $100 \mathrm{mg} / \mathrm{L}$. 


\subsubsection{2. Efeito da concentração de metassilicato de sódio na depressão do quartzo}

Para avaliar o efeito da concentração de metassilicato de sódio na depressão de quartzo, os ensaios de microflotação foram realizados em pH 3 e concentração do biossurfactante de $100 \mathrm{mg} / \mathrm{L}$. A Figura 45 apresenta os resultados de microflotação, mostrando que a depressão de quartzo é favorável com concentração de metassilicato de sódio de $100 \mathrm{mg} / \mathrm{L}$. Já para concentrações de metassilicato de sódio maiores ou iguais de $200 \mathrm{mg} / \mathrm{L}$, a depressão de quartzo diminui e por conseguinte a flotabilidade do mineral aumentou.

Silva (2011) realizou estudos de flotação de calcita e quartzo em tubo de Hallimond, usando silicato de sódio como depressor. Os resultados obtidos mostraram que em todos os sistemas testados, a eficiência do silicato de sódio aumentou com a concentração. Em concentrações acima de $1500 \mathrm{~g} / \mathrm{t}$, obteve-se quase a depressão total, sendo 96\% para a calcita e 97\% para o quartzo. A variação do modulo (relação entre o dióxido de silício e o oxido de sódio) do silicato de sódio não alterou o seu desempenho na flotação do quartzo com amina (150 g/t). A faixa de $\mathrm{pH}$ mais eficiente foi observada entre 5 e 8 . A partir do $\mathrm{pH}$ 11 o silicato de sódio não funcionou como depressor.

Jin et al. (2016) estudaram o efeito da concentração de silicato de sódio na flotação de kianita e quartzo. Os testes de flotação foram realizados em uma célula de flotação mecanica de $35 \mathrm{~mL}$ e o pH da solução contendo sulfonato de sódio $\left(5 \times 10^{-4} \mathrm{~mol} / \mathrm{L}\right)$ e $\mathrm{Fe}^{3+}\left(1,5 \times 10^{-4} \mathrm{~mol} / \mathrm{L}\right)$ foi ajustado para 4 . Os autores observaram que o silicato de sódio tem uma maior deprresão na flotação de quartzo ativado pelo ferro do que a kianita. 


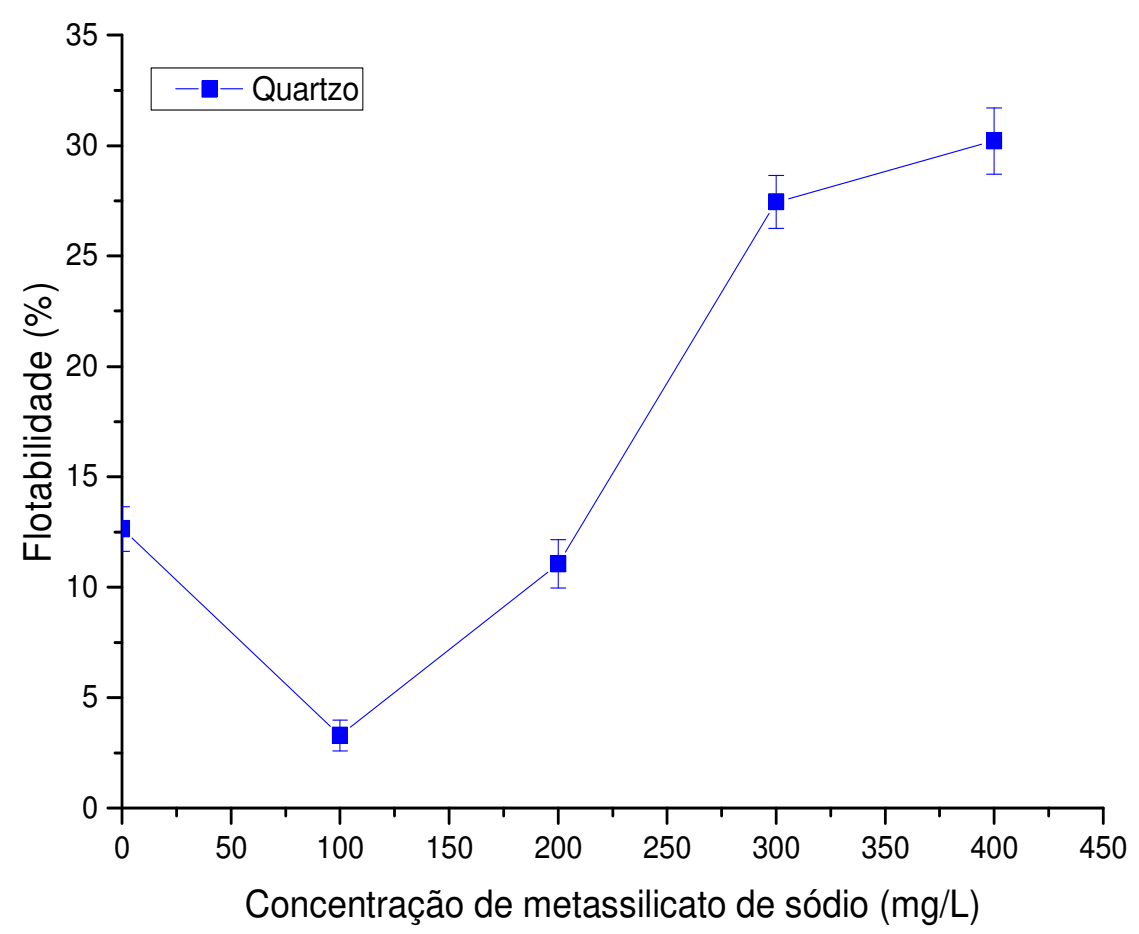

Figura 45. Efeito da concentração de metassilicato de sódio na depressão de quartzo. Concentração do biossurfactante de $100 \mathrm{mg} / \mathrm{L}$ e pH da solução $=3$.

\subsubsection{3.}

\section{Efeito do pH na microflotação do sistema hematita-quartzo}

$\mathrm{O}$ efeito do $\mathrm{pH}$ da solução na microflotação do sistema hematita-quartzo foi avaliado a partir do teor de ferro da mistura flotada. A mistura teve boa recuperação no pH 3, com recuperação de $49,67 \%$ e teor de ferro de $60,09 \%$, tal como é mostrado na Figura 46. Já para o valor do pH 5, a recuperação foi menor e, para valores do $\mathrm{pH}$ acima de 5 , a recuperação foi nula. 


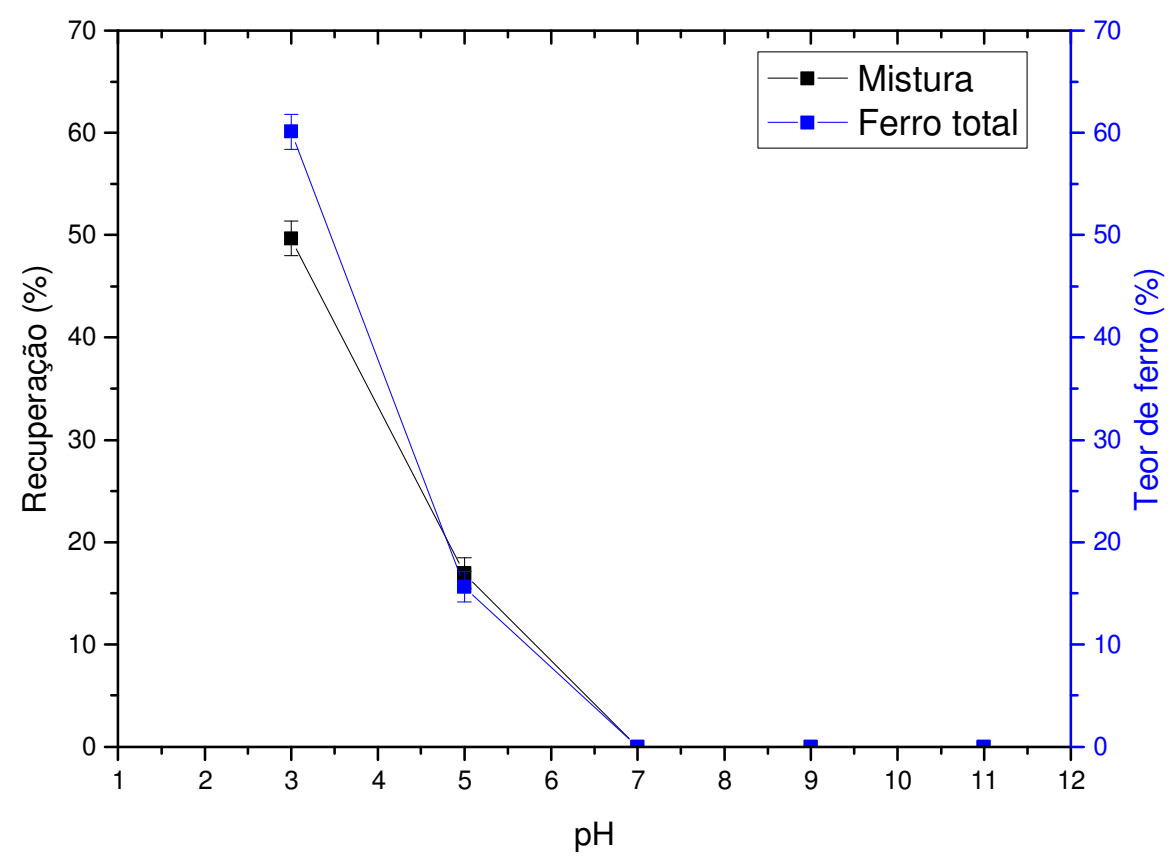

Figura 46. Microflotação do sistema hematita-quartzo e teor de ferro em função do pH da solução. Concentração do metassilicato de sódio de 100 mg/L e concentração do biossurfactante de $100 \mathrm{mg} / \mathrm{L}$. Relação da mistura hematita-quartzo $(1: 1)$.

A Figura 47 apresenta a recuperação da hematita e de quartzo em função do pH da solução, usando concentração do metassilicato de sódio de $100 \mathrm{mg} / \mathrm{L} \mathrm{e}$ concentração do biossurfactante de $100 \mathrm{mg} / \mathrm{L}$. Os resultados mostram que a recuperação máxima de hematita e de quartzo foi ao redor do $\mathrm{pH} 3$, cujos valores de recuperação estão em torno de $44 \%$ e $27 \%$, respectivamente. Observa-se também que o valor ótimo para uma possível flotação do sistema hematita-quartzo é no $\mathrm{pH} 3$.

A separação seletiva entre hematita e quartzo foi também estudada por Mesquita et al. (2003). Os testes de microflotação foram realizados com uma concentração de $R$. opacus de $600 \mathrm{~g} / \mathrm{t}$. A partir dessas condições, os resultados demonstraram grande potencial da bactéria $R$. opacus como um coletor a $\mathrm{pH}$ neutro em sistemas de microflotação direta de hematita onde o teor de ferro é baixo ou em materiais onde a hematita é um contaminante.

Wengang et al. (2011) usaram o coletor N-lauril-1,3-diaminopropano e o depressor amido para separar quartzo de misturas hematita-quartzo. Os resultados de flotação mostraram que as melhores recuperações podem ser alcançadas no $\mathrm{pH}$ 
7,27 usando concentrações de $58.3 \mathrm{mg} / \mathrm{L}$ de coletor e $6.67 \mathrm{mg} / \mathrm{L}$ de depressor. Os teores de ferro encontrados nos concentrados foram de $58,45 \%, 62,78 \%$ e $63,72 \%$ quando a proporção em massa de hematita para quartzo foi de $2: 3,1: 1$ e 3:2, respectivamente.

Sahoo et al. (2016a) estudaram a flotação de misturas sintéticas usando ácido oleico e dodecilamina como coletores. Os resultados de flotação com ácido oleico de $76 \mathrm{~g} / \mathrm{t}$ mostraram uma recuperação de 43,2\% de mistura hematitaquartzo, com teor de $61,2 \%$ de Fe. Por outro lado, usando uma concentração de dodecilamina de $\sim 32 \mathrm{~g} / \mathrm{L}$ obtém-se uma recuperação de $\sim 86,5 \%$ de mistura hematita-quartzo, com teor de $\sim 38 \%$ de Fe.

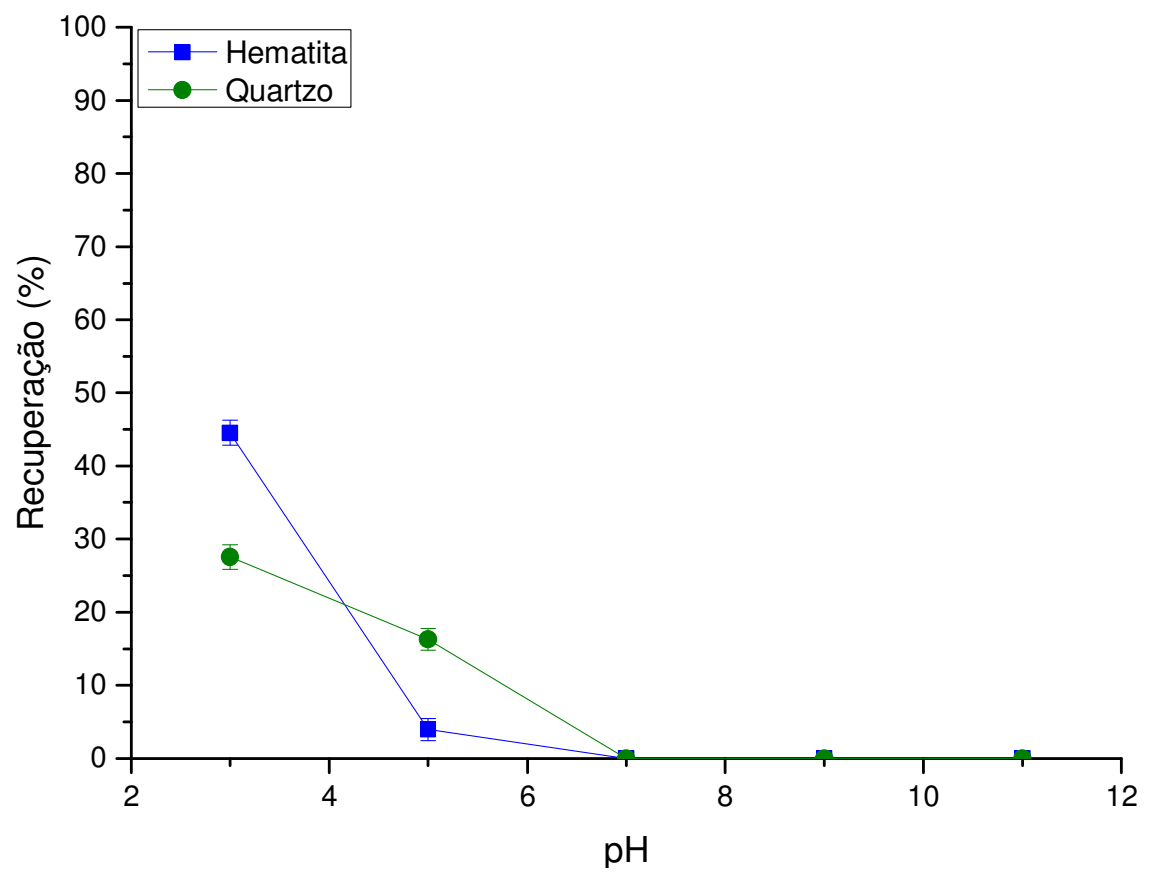

Figura 47. Recuperação da hematita e do quartzo em função do pH da solução. Concentração do metassilicato de sódio de $100 \mathrm{mg} / \mathrm{L}$ e concentração do biossurfactante de 100 mg/L. Relação da mistura hematita-quartzo (1:1).

\subsubsection{4. Efeito da concentração do metassilicato de sódio na microflotação do sistema hematita-quartzo}

Conhecendo-se que a microflotação do sistema hematita-quartzo é favorável no $\mathrm{pH} 3$, foram realizados ensaios de microflotação em função da concentração de metassilicato de sódio e consequentemente análises química de teor de ferro, tal 
como é mostrado na Figura 48. A partir da mesma é possível observar que os melhores valores de teor de ferro (em torno de 60\%) foram alcançados com concentrações de metassilicato de sódio de 0,100 e $200 \mathrm{mg} / \mathrm{L}$, sendo favorável na ausência do depressor por ter maior flotabilidade da mistura.

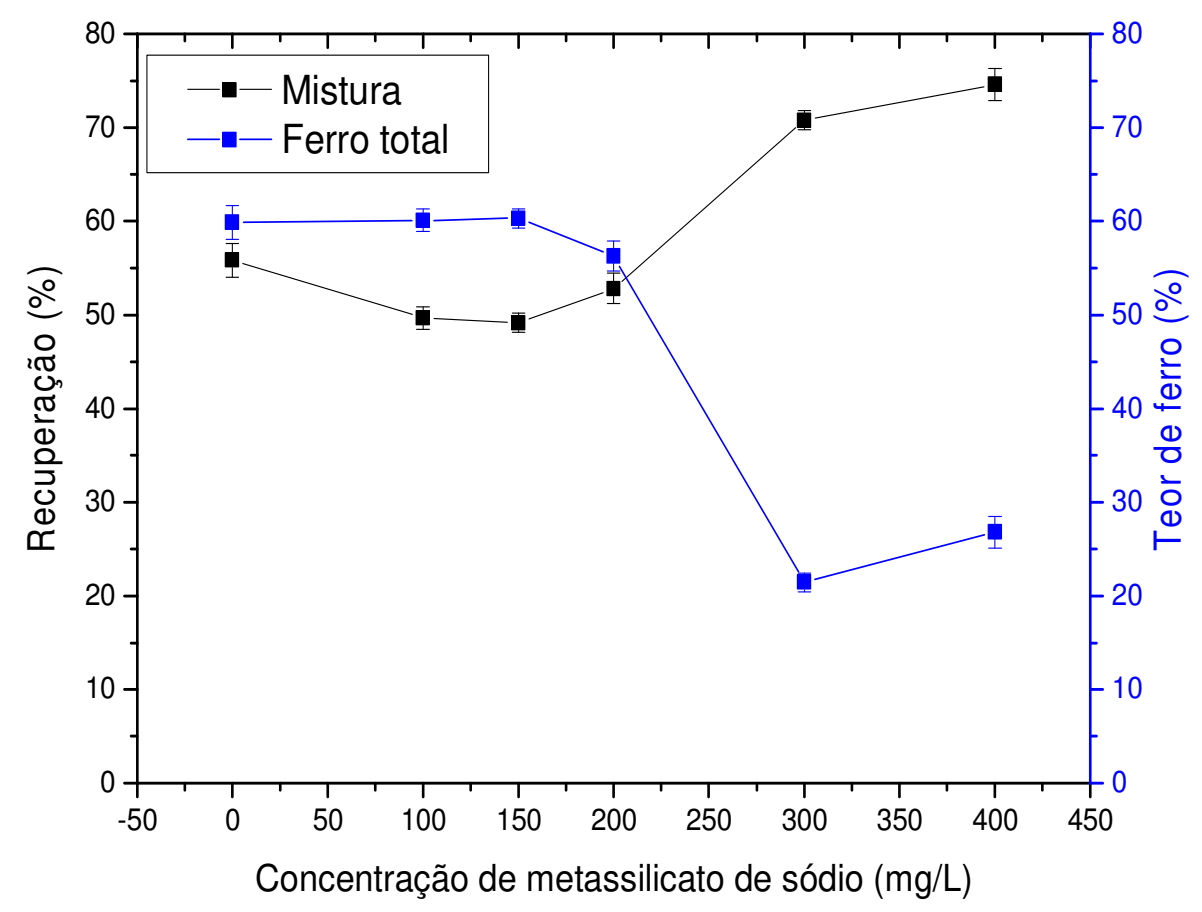

Figura 48. Microflotação do sistema hematita-quartzo e teor de ferro em função da concentração do metassilicato de sódio. Concentração do biossurfactante de $100 \mathrm{mg} / \mathrm{L}$ e $\mathbf{p H}$ da solução $=3$. Relação da mistura hematita-quartzo (1:1).

A recuperação da hematita e do quartzo é apresentada na Figura 49. Os resultados mostraram que a recuperação máxima de hematita foi de 49,88\% $(27,99 \%$ de quartzo) e foi na ausência de metassilicato de sódio. Observa-se também que para concentrações de silicato de sódio de 100 - $200 \mathrm{mg} / \mathrm{L}$ a recuperação da hematita foi em torno de 44\%. Por outro lado, a recuperação do quartzo foi máxima na concentração de metassilicato de sódio de $300 \mathrm{mg} / \mathrm{L}$, com recuperação de 54,76\% (22,65\% de hematita). Considerando esses resultados, a microflotação direta de hematita a partir do sistema hematita-quartzo é favorável em pH 3 e em concentrações mínimas de depressor. 
Lopes \& Lima (2009) realizaram ensaios de microflotação de hematita e quartzo usando metassilicato de sódio como depressor. Os resultados mostraram que o metassilicato de sódio foi mais efetivo na depressão da hematita: $0,7 \%$ de recuperação da hematita contra $16 \%$ de recuperação para o quartzo usando $20 \mathrm{~g} / \mathrm{L}$ de metassilicato de sódio em ambos os casos. Portanto concluíram que o metassilicato de sódio não é um depressor seletivo no sistema hematita/quartzo quando o oleato de sódio é usado como coletor.

No trabalho de Jin et al. (2016) estudaram a separação de kianita do quartzo usando uma mistura de kianita-quartzo (1:1). Os resultados de recuperação foram de $78 \%$ para a kianita e $13 \%$ para o quartzo, o qual sugerem que uma separação eficaz de kianita do quartzo poderia ser alcançado no $\mathrm{pH} 4$ para uma solução de $1,5 \times 10^{-4} \mathrm{~mol} / \mathrm{L}$ de $\mathrm{Fe}^{+}, 1 \times 10^{-3} \mathrm{~mol} / \mathrm{L}$ de silicato de sodio e $5 \times 10^{-4} \mathrm{~mol} / \mathrm{L}$ de sulfonato de sodio.

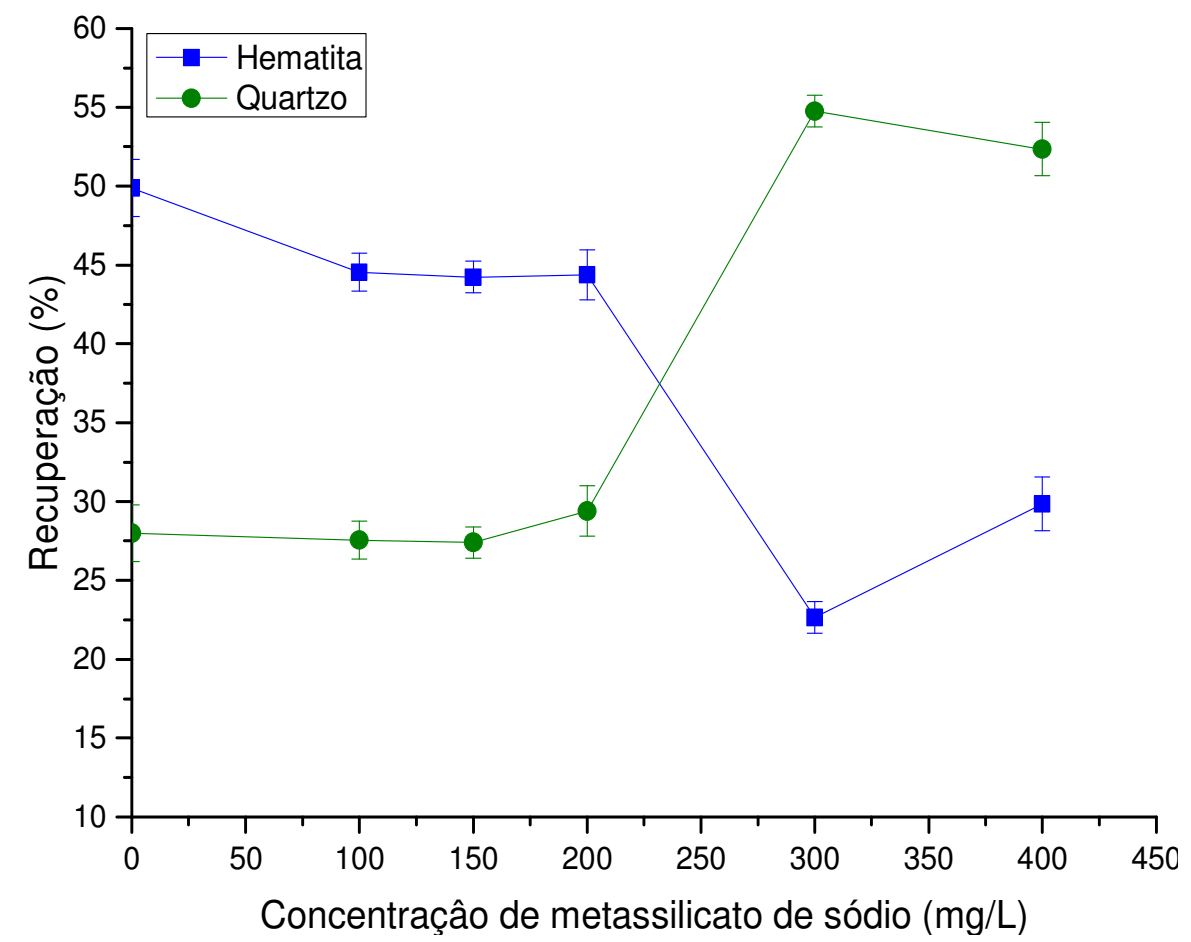

Figura 49. Recuperação da hematita e do quartzo em função da concentração do metassilicato de sódio. Concentração do biossurfactante de $100 \mathrm{mg} / \mathrm{L}$ e pH da solução $=3$. Relação da mistura hematita-quartzo $(1: 1)$. 


\section{6.}

\section{Cinética de microflotação}

A cinética de flotação estuda a variação da massa mineral flotada de acordo com o tempo de flotação, originando uma relação do tipo cinético. Esse relacionamento permite elucidar o efeito das variáveis e detectar aquelas que constituem fatores determinantes no processo. Assim sendo, tanto do ponto de vista prático como teórico, a flotabilidade das partículas minerais no sistema de flotação pode ser compreendida melhor pela constante de velocidade.

\subsection{1.}

\section{Cinética da flotabilidade da hematita}

A Figura 50 apresenta a flotabilidade da hematita em função do tempo de flotação. Os testes de flotação foram realizados com uma concentração do biossurfactante de $10 \mathrm{mg} / \mathrm{L}$ e o pH da solução foi ajustado para 3. Os resultados obtidos mostraram que o biossurfactante conseguiu a recuperação total de hematita (100\%) a partir dos primeiros 120 segundos de flotação.

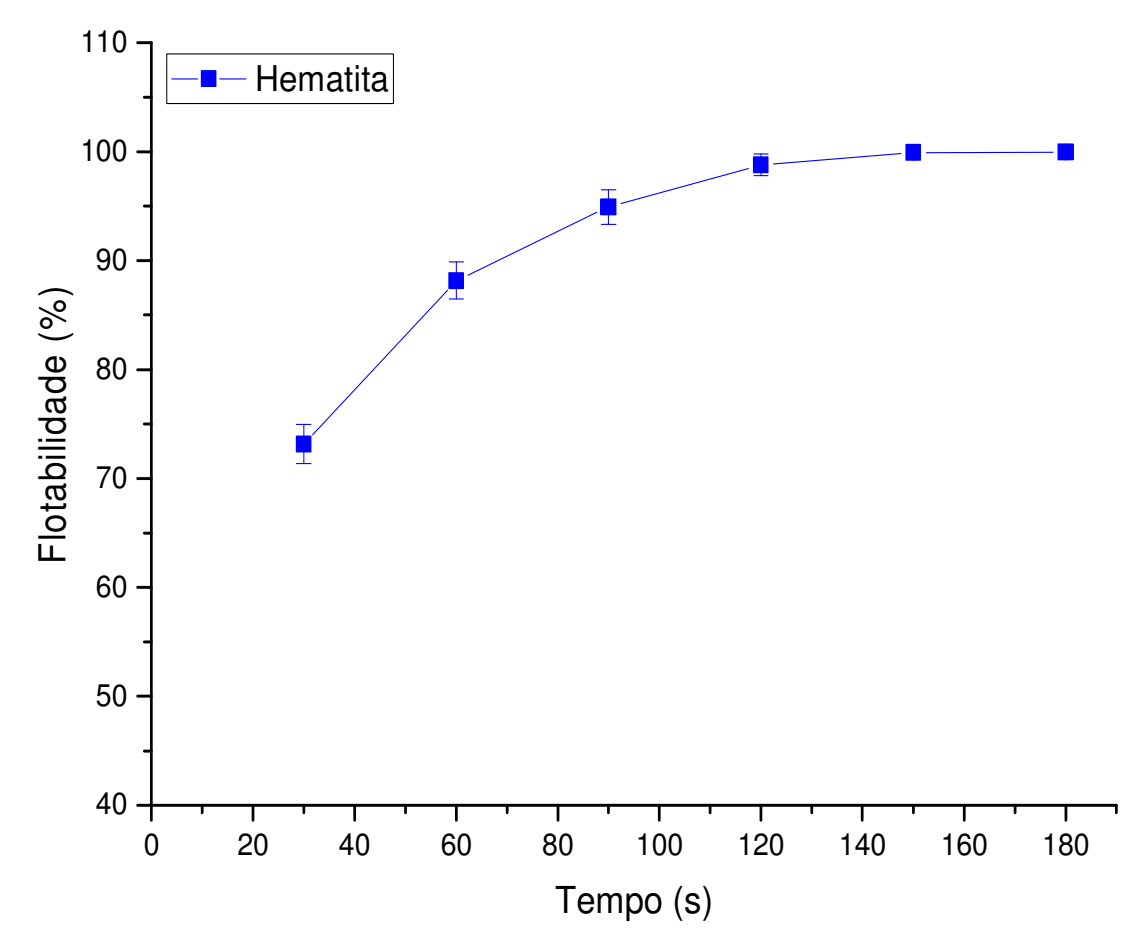

Figura 50. Flotabilidade de hematita em função do tempo. Concentração do biossurfactante: $10 \mathrm{mg} / \mathrm{L} \mathrm{e} \mathbf{p H}=3$. 
A cinética de microflotação de hematita foi representada pelos modelos clássicos de primeira ordem, segunda ordem e ordem fracionária e, a determinação das suas constantes cinéticas foi realizada através da linearização de seus modelos. As constantes cinéticas e coeficientes de correlação $\left(\mathrm{R}^{2}\right)$ obtidas após análise são apresentadas na Tabela 18. A partir dos coeficientes de correlação, foi possível assumir que quanto o modelo de primeira ordem como o modelo de ordem fracionária foram os que melhor ajustaram os dados experimentais, pois os seus valores de $\mathrm{R}^{2}$ foram de 0,98 . Observaram-se também valores de constantes cinéticas iguais quanto no modelo de primeira ordem como no modelo de ordem fracionária devido que o valor de máxima flotabilidade $\left(\mathrm{R}_{\infty}=1\right)$ considerado no modelo de ordem fracionária foi de $100 \%$ e assim resultando na mesma equação cinética para ambos os modelos.

Tabela 18. Constantes cinéticas da microflotação de hematita

\begin{tabular}{c|c|c|c|c|c|c|c}
\hline \multirow{2}{*}{ Ordem } & \multicolumn{2}{|c|}{$\mathbf{n}=\mathbf{1}$} & \multicolumn{2}{c|}{$\mathbf{n}=\mathbf{2}$} & \multicolumn{3}{c}{ Fracionária } \\
\cline { 2 - 8 } Fração & $\begin{array}{c}\mathbf{K}_{\mathbf{1}} \\
\left(\mathbf{m i n}^{-1}\right)\end{array}$ & $\mathbf{R}^{\mathbf{2}}$ & $\begin{array}{c}\mathbf{K}_{\mathbf{2}} \\
\left(\mathbf{g}^{-1} \cdot \mathbf{m i n}^{-1}\right)\end{array}$ & $\mathbf{R}^{\mathbf{2}}$ & $\mathbf{R}_{\infty}$ & $\begin{array}{c}\mathbf{K}_{\mathbf{3}} \\
\left(\mathbf{m i n}^{-1}\right)\end{array}$ & $\mathbf{R}^{\mathbf{2}}$ \\
\hline $\mathbf{( - 1 0 6}+\mathbf{7 5} \boldsymbol{\mu m})$ & 0,0409 & 0,98 & 7,2541 & 0,53 & 1 & 0,0409 & 0,98 \\
\hline
\end{tabular}

A partir da Tabela 18, foi observado que ambos os modelos primeira ordem e ordem fracionária alcançaram as mesmas constantes cinéticas e coeficientes de correlação como causa do mesmo ajuste linear aos dados experimentais (Figura 51). Também foi observado que o modelo de segunda ordem alcançou o valor de $\mathrm{R}^{2}$ de 0,53 qual foi rejeitado por seu baixo ajuste aos dados experimentais (Apêndice 4.1). 


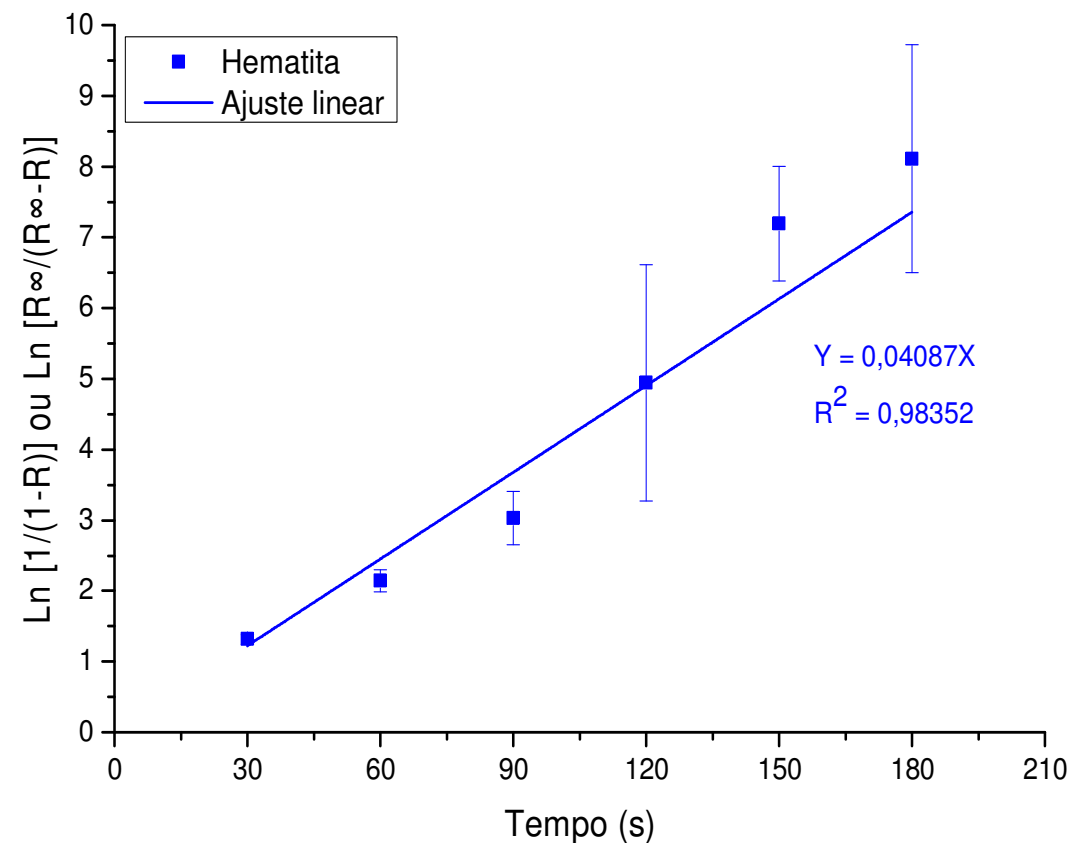

Figura 51. Ajuste linear da cinética de microflotação de hematita usando tanto o modelo de primeira ordem como o modelo de ordem fracionária.

Outros autores como Hernáinz \& Calero (2001) e Hernáinz et al. (2005) na flotação de celestita e calcita e, minério de fosfato, respectivamente obtiveram melhores resultados de cinética de flotação seguindo o modelo de ordem fracionária. Já Yalcin \& Kelebek (2011) e Olivera et al. (2017) na flotação de minério de ouro piritico e hematita, respectivamente obtiveram melhores ajustes dos dados experimentais com o modelo cinético de segunda ordem.

\subsection{2.}

\section{Cinética da flotabilidade do quartzo}

Para o quartzo, os testes de microflotação foram realizados com uma concentração do biossurfactante de $10 \mathrm{mg} / \mathrm{L}$ e o pH da solução foi ajustado para 3. A Figura 52 apresenta a flotabilidade do quartzo em função do tempo de flotação. Os resultados obtidos mostram que a recuperação de quartzo é ascendente, e o biossurfactante conseguiu atingir uma recuperação máxima de 17,51\% em 180 segundos de flotação. 


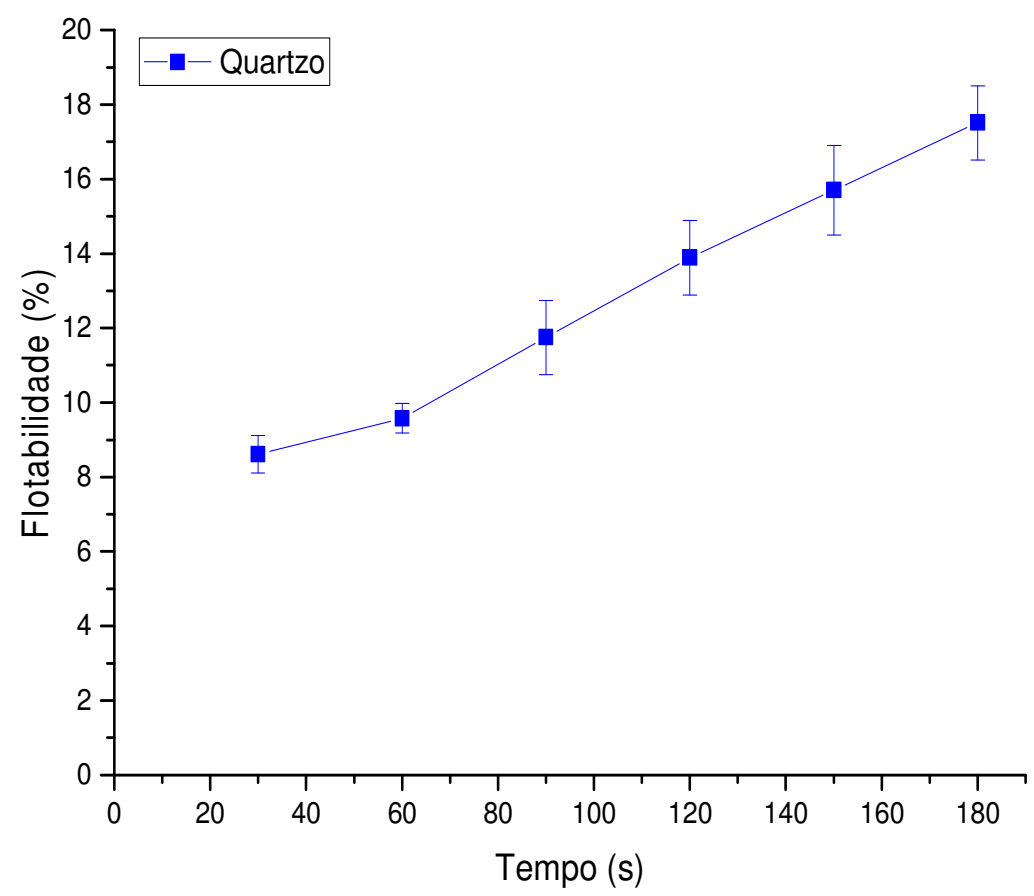

Figura 52. Flotabilidade de quartzo em função do tempo. Concentração do biossurfactante: $10 \mathrm{mg} / \mathrm{L} \mathrm{e} \mathbf{p H}=3$.

A cinética de microflotação de quartzo foi representada pelos mesmos modelos que foram aplicados na microflotação de hematita. As constantes cinéticas e coeficientes de correlação $\left(\mathrm{R}^{2}\right)$ obtidas após análise são mostradas na Tabela 19.

Tabela 19. Constantes cinéticas da microflotação de quartzo

\begin{tabular}{c|c|c|c|c|c|c|c}
\hline \multirow{2}{*}{$\begin{array}{c}\text { Ordem } \\
\text { Fração }\end{array}$} & \multicolumn{2}{|c|}{$\mathbf{n}=\mathbf{1}$} & \multicolumn{2}{c|}{$\mathbf{n}=\mathbf{2}$} & \multicolumn{3}{c}{ Fracionária } \\
\cline { 2 - 8 }$\left(\mathbf{K}_{\mathbf{1}}\right.$ & $\left.\mathbf{R}^{\mathbf{1}}\right)$ & $\begin{array}{c}\mathbf{K}_{\mathbf{2}} \\
\left(\mathbf{g}^{-1} \cdot \mathbf{m i n}^{-1}\right)\end{array}$ & $\mathbf{R}^{2}$ & $\mathbf{R}_{\infty}$ & $\begin{array}{c}\mathbf{K}_{3} \\
\left(\mathbf{m i n}^{-1}\right)\end{array}$ & $\mathbf{R}^{2}$ \\
\hline $\mathbf{( - 1 0 6}+\mathbf{7 5} \boldsymbol{\mu m})$ & 0,0012 & 0,94 & 0,0013 & 0,95 & 0,21 & 0,0096 & 0,98 \\
\hline
\end{tabular}

A partir da Tabela 19, foi observado que o modelo de ordem fracionária foi o que melhor ajustou os dados experimentais, com o valor de $\mathrm{R}^{2}$ de 0,98 (Figura 53). Também foi observado que os modelos de primeira ordem e segunda ordem obtiveram coeficientes de correlação de 0,94 e 0,95 respectivamente, mas foram 
rejeitados por seu baixo ajuste aos dados experimentais. $\mathrm{O}$ ajuste linear desses modelos é mostrado no Apêndice 4.2 e Apêndice 4.3, respectivamente.

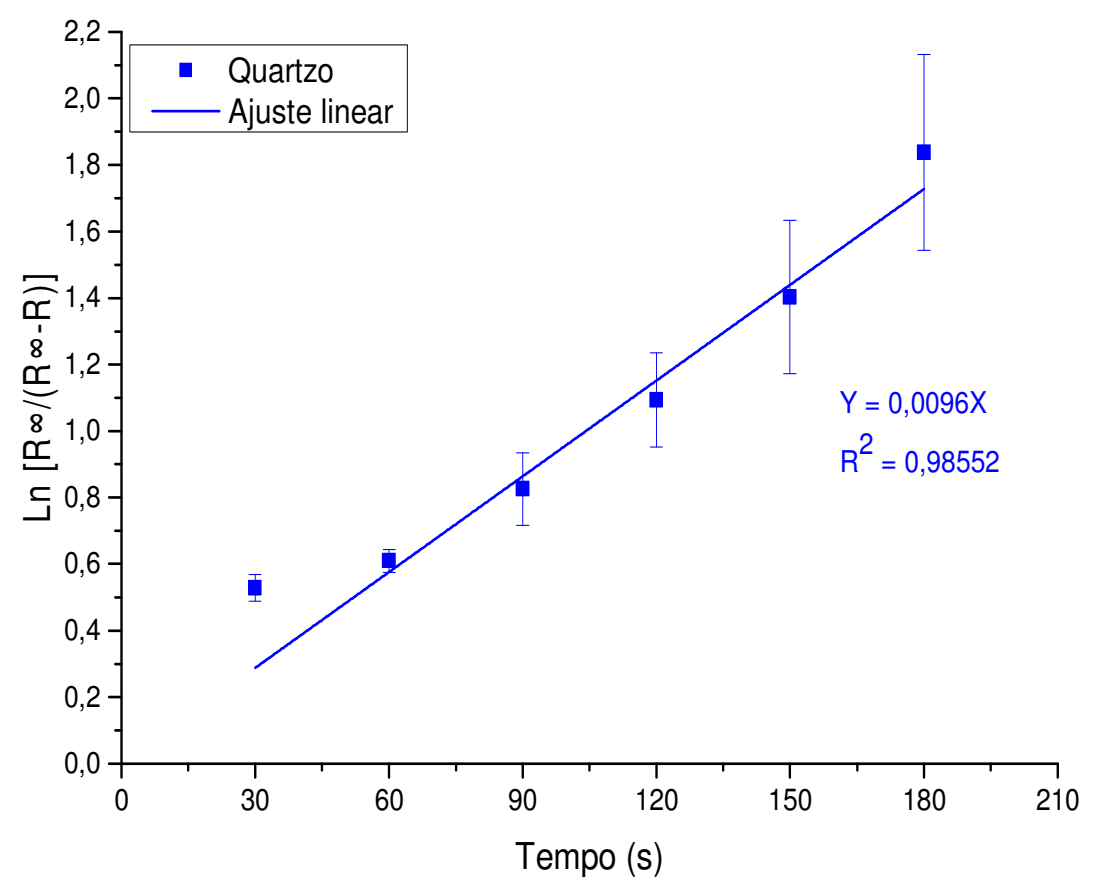

Figura 53. Ajuste linear da cinética de microflotação de quartzo usando o modelo de ordem fracionária.

Merma \& Torem (2015) estudaram a cinética de flotabilidade do quartzo usando o Rhodococcus opacus como biorreagente. Os resultados mostraram que o modelo cinético de primeira ordem ajustou melhor aos dados experimentais e observou-se uma relação direta entre a taxa de flotabilidade e o tamanho de partícula mineral. Similarmente, foi observado no trabalho de Larsen \& Kleiv (2015) que encontraram bons ajustes com o modelo cinético de primeira ordem aos dados de flotabilidade de quartzo usando Flotanol C07, Dowfroth 400 e Brij 58 como reagentes espumantes. 


\section{5 \\ Conclusões}

Diante os resultados obtidos nesta tese, pode-se concluir que:

A utilização do biossurfactante solúvel produzido por Rhodococcus erythropolis como biorreagente coletor de hematita no sistema hematita-quartzo foi viável, demonstrando o seu grande potencial e mostrando-se bastante promissor para uma futura aplicação na indústria da flotação mineral.

As análises bioquímicas de proteínas, carboidratos e lipídeos determinaram que o biossurfactante solúvel é composto principalmente por proteínas, com valores de $66,79 \%, 10,73 \%$ e $3,57 \%$, respectivamente.

Os ensaios de tensão superficial mostraram que o biorreagente conseguiu reduzir a tensão superficial da água deionizada de $73,72 \mathrm{mN} / \mathrm{m}$ para $62,89 \mathrm{mN} / \mathrm{m}$, com uma concentração de biossurfactante de 200 mg/L e em pH 3. Portanto, o biossurfactante solúvel tem uma capacidade moderada para reduzir a tensão superficial da água, mas não é tão eficiente como um biossurfactante refinado.

As medições de potencial zeta indicaram que o ponto isoelétrico dos minerais hematita e quartzo é em torno do pH 5,2 e 1,9, respectivamente, e após interação com o biossurfactante, ambos os pontos isoelétricos mudaram para o $\mathrm{pH}$ 4,4 devido à adsorção e interações do biossurfactante na superfície dos minerais.

As medidas de ângulo de contato identificaram que a superfície de hematita exibiu caráter mais hidrofóbico que a superfície de quartzo tanto antes da interação como após da interação com o biossurfactante. Antes da interação seus valores foram de $31,5^{\circ}$ e $10,5^{\circ}$, respectivamente. Já após interação, os máximos valores foram encontrados em torno do $\mathrm{pH} 3$, com $56^{\circ}$ e $39^{\circ}$, respectivamente. 
Os experimentos de adsorção revelaram maior adsorção do biossurfactante na superfície de hematita do que a superfície de quartzo. Para ambos os minerais, a maior adsorção foi alcançada no pH 3 e na concentração de 200 mg/L, com valores de 11,68 e $6,28 \mathrm{mg}$ de biossurfactante por grama de mineral, respectivamente.

Os espectros FTIR da interação hematita-biossurfactante e quartzobiossurfactante confirmaram a presença de grupos funcionais característicos do biossurfatante sobre as superfícies minerais. $\mathrm{Na}$ superfície de hematita foram encontrados grupos funcionais como $\mathrm{NH}, \mathrm{CH} 2, \mathrm{CH} 3$ e $\mathrm{C}=\mathrm{O}$, enquanto na superfície do quartzo grupos funcionais de $\mathrm{NH}$ e $\mathrm{C}=\mathrm{O}$.

A microflotação de hematita e de quartzo utilizando o biossurfactante solúvel como biorreagente coletor depende da concentração do biossurfactante e do valor de $\mathrm{pH}$ da solução. $\mathrm{O}$ melhores resultados de flotabilidade de hematita $\mathrm{e}$ de quartzo foram encontrados em pH 3 e na concentração de $100 \mathrm{mg} / \mathrm{L}$, com percentagem em torno de $99,88 \%$ e $31,05 \%$, respectivamente.

O modelo de regressão polinomial determinou que a flotabilidade de hematita segue uma função de $4^{\mathrm{a}}$ ordem para o $\mathrm{pH}$ da solução e de $3^{\mathrm{a}}$ ordem para a concentração do biossurfactante, com um coeficiente de correlação $\left(\mathrm{R}^{2}\right)$ igual a $95,46 \%$, enquanto a flotabilidade de quartzo segue uma função de $4^{\mathrm{a}}$ ordem para o pH da solução e de $4^{\mathrm{a}}$ ordem para a concentração do biossurfactante, com um coeficiente de correlação $\left(\mathrm{R}^{2}\right)$ igual a $98,73 \%$.

Os testes de microflotação do sistema hematita-quartzo com diferentes relações de mistura realizados em pH 3 e concentrações do biossurfactante de 50 e $100 \mathrm{mg} / \mathrm{L}$ mostraram que o biossurfactante é mais seletivo para hematita do que quartzo. Também foi observado que na microflotação do sistema hematita-quartzo (1:1) realizada em pH 3 e concentração do biossurfactante de $50 \mathrm{mg} / \mathrm{L}$, a recuperação máxima de hematita foi de 49,88\% (27,99\% de quartzo) e foi na ausência do metassilicato de sódio, enquanto a recuperação de quartzo foi máxima na concentração de metassilicato de sódio de $300 \mathrm{mg} / \mathrm{L}$, com recuperação de $54,76 \%$ (22,65\% de hematita). 
O estudo cinético mostrou que os dados experimentais da flotabilidade de hematita foram mais bem ajustados quanto ao modelo cinético de primeira ordem como ao modelo cinético de ordem fracionária, com o valor de $R^{2}$ de 0,98 , enquanto os dados experimentais da flotabilidade de quartzo foram mais bem ajustados ao modelo cinético de ordem fracionária, com o valor de $\mathrm{R}^{2}$ de 0,98 . 


\section{6 Recomendações para futuros trabalhos}

A fim de dar continuidade aos estudos de produção de biossurfactante por Rhodococcus erythropolis, são sugeridas algumas recomendações, com o intuito de aumentar a eficiência do processo produtivo e projetando-se para uma futura aplicação na indústria mineral:

Estudar a influência de diferentes meios de cultura na produção de biossurfactante por Rhodococcus erythropolis.

Produzir biossurfactante em biorreator usando os melhores parâmetros testados.

Otimizar o processo de extração e de purificação do biossurfactante.

Separar e caracterizar os bioprodutos presentes no biossurfactante extraído.

Devem ser feitos ensaios de flotação com minério de ferro real em célula mecânica convencional ou em coluna de flotação para confirmar a efetividade do biossurfactante como reagente. 


\section{Referências bibliográficas}

ABDEL-KHALEK, N. A. et al. Bio-flotation of Egyptian Phosphate Using Desulfvibrio Desulfuricans Bacteria. Journal of Mining World Express, v. 4, n. 0, p. 19, 2015.

AGHAZADEH, S.; MOUSAVINEZHAD, S. K.; GHARABAGHI, M. Chemical and colloidal aspects of collectorless flotation behavior of sulfide and nonsulfide minerals. Advances in Colloid and Interface Science, v. 225, p. 203-217, 1 nov. 2015.

ALI, S. S. M. et al. Introducing inverse gas chromatography as a method of determining the surface heterogeneity of minerals for flotation. Powder Technology, v. 249, p. 373-377, 1 nov. 2013.

ALMEIDA, F. C. G. Produção de biossurfactante por Bacillus licheniformis utilizando rejeito do abacaxi (Ananas comosus L.) como fonte renovável e de baixo custo. Dissertação de Mestrado apresentada como pre-requisito para obtenção do título de Mestre pelo Programa de Pós-Graduação em Desenvolvimento de Processos Ambientais-Recife: UNICAP, 2009.

ALVAREZ-SILVA, M. et al. A comparison of the predictability of batch flotation kinetic models. Minerals Engineering, v. 99, p. 142-150, 1 dez. 2016.

ARAUJO, A. C.; VIANA, P. R. M.; PERES, A. E. C. Reagents in iron ores flotation. Minerals Engineering, Reagents '04. v. 18, n. 2, p. 219-224, 1 fev. 2005.

AZAM, M. R. et al. Static adsorption of anionic surfactant onto crushed Berea sandstone. Journal of Petroleum Exploration and Production Technology, v. 3, n. 3, p. 195-201, 1 set. 2013.

BARROS, L. A. F.; FERREIRA, E. E.; PERES, A. E. C. Floatability of apatites and gangue minerals of an igneous phosphate ore. Minerals Engineering, XXXX. v. 21, n. 12, p. 994-999, 1 nov. 2008.

BELL et al. The genus Rhodococcus. Journal of Applied Microbiology, v. 85 , n. 2, p. 195-210, 1 ago. 1998.

BLIGH, E. G.; DYER, W. J. A rapid method of total lipid extraction and purification. Canadian journal of biochemistry and physiology, v. 37, n. 8, p. 911-917, 1959. 
BOTERO, A. E. C. Bioflotação de magnesita, calcita e barita usando Rhodococcus opacus como biorreagente. Tese apresentada como requisito parcial para obtenção do título de Doutor pelo Programa de PósGraduação em Engenharia de Materiais e de Processos Químicos e Metalúrgicos-Rio de Janeiro: PUC-Rio, 2007.

BOTERO, A. E. C.; TOREM, M. L.; MESQUITA, L. M. S. DE. Perspectiva e potencial aplicação de biorreagentes na flotação de minerais. Rem: Revista Escola de Minas, v. 61, n. 1, p. 57-61, mar. 2008.

BOTERO, A. E. C.; TOREM, M. L.; SOUZA DE MESQUITA, L. M. Fundamental studies of Rhodococcus opacus as a biocollector of calcite and magnesite. Minerals Engineering, Selected papers from Reagents '06, Cape Town, South Africa, November 2006. v. 20, n. 10, p. 10261032, 1 ago. 2007.

BRYANT, F. O. Improved Method for the Isolation of Biosurfactant Glycolipids from Rhodococcus sp. Strain H13A. Applied and Environmental Microbiology, v. 56, n. 5, p. 1494-1496, maio 1990.

BULATOVIC, S. M. Handbook of flotation reagents: chemistry, theory and practice: volume 1: flotation of sulfide ores. [s.l.] Elsevier, 2007.

CALFA, B. A.; TOREM, M. L. Biorreagentes: aplicações na remoção de metais pesados contidos em efluentes líquidos por biossorção/bioflotação. Rem: Revista Escola de Minas, v. 60, n. 3, p. 537-542, set. 2007.

CARVALHO, C. C. C. R. Adaptation of Rhodococcus erythropolis cells for growth and bioremediation under extreme conditions. Research in Microbiology, v. 163, n. 2, p. 125-136, 1 fev. 2012.

CARVALHO, C. C. C. R. DE; FONSECA, M. M. R. DA. The remarkable Rhodococcus erythropolis. Applied Microbiology and Biotechnology, v. 67, n. 6, p. 715-726, 1 jun. 2005.

CHRISTOVA, N.; STOINEVA, I. Trehalose Biosurfactants. In: Biosurfactants: Research Trends and Applications. [s.I.] CRC Press, 2014.

CIAPINA, E. M. P. Produção de biossurfactante por rhodococcus erythropolis em biorreator de bancada e avaliação do seu efeito na biodegradação de borra oleosa da indústria do petróleo. Tese Apresentada ao Programa de Pós-Graduação em Tecnologia de Processos Químicos e Bioquímicos para a Obtenção do Grau de DoutorRio de Janeiro: UFRJ, 2008.

CORONEL-LEÓN, J. et al. Lichenysin-geminal amino acid-based surfactants: Synergistic action of an unconventional antimicrobial mixture. Colloids and Surfaces B: Biointerfaces, v. 149, p. 38-47, 1 jan. 2017.

CUNHA FILHO, F. J. V. DA. Estudo reológico de um fluido de perfuração à base $n$-parafina, utilizando argila modificada com 
tensoativo. Master's Thesis-[s.l.] Universidade Federal do Rio Grande do Norte, 2015.

DECESARO, A. et al. Biosurfactants in Bioremediation Process. Revista Ciencias Exatas e Naturais, v. 17, n. 1, 2015.

DEO, N.; NATARAJAN, K. A. Interaction of Bacillus polymyxa with some oxide minerals with reference to mineral beneficiation and environmental control. Minerals Engineering, v. 10, n. 12, p. 1339-1354, 1 dez. 1997.

DEO, N.; NATARAJAN, K. A. Studies on interaction of Paenibacillus polymyxa with iron ore minerals in relation to beneficiation. International Journal of Mineral Processing, v. 55, n. 1, p. 41-60, 1 out. 1998.

DEO, N.; NATARAJAN, K. A.; SOMASUNDARAN, P. Mechanisms of adhesion of Paenibacillus polymyxa onto hematite, corundum and quartz. International Journal of Mineral Processing, Minerals Bioprocessing IV. v. 62, n. 1, p. 27-39, 1 maio 2001.

DESAI, J. D.; BANAT, I. M. Microbial production of surfactants and their commercial potential. Microbiology and Molecular Biology Reviews, v. 61, n. 1, p. 47-64, mar. 1997.

DEVORE, J. L. Probability and Statistics for Engineering and the Sciences. [s.l.] Cengage Learning, 2015.

DHANARAJAN, G.; SEN, R. Amphiphilic Molecules of Microbial Origin: Classification, Characteristics, Genetic Regulations, and Pathways for Biosynthesis. In: Biosurfactants: Research Trends and Applications. [s.l.] CRC Press, 2014.

DIDYK, A. M.; SADOWSKI, Z. Flotation of serpentinite and quartz using biosurfactants. Physicochem Probl Miner Process, v. 48, n. 2, p. 607618, 2012.

DUBEL, J. et al. Microorganisms as chemical reagents: The hematite system. Minerals Engineering, Special Issue Reagents in Minerals Engineering. v. 5, n. 3, p. 547-556, 1 mar. 1992.

DWYER, R. et al. Bioflotation and bioflocculation review: microorganisms relevant for mineral beneficiation. Mineral Processing and Extractive Metallurgy, v. 121, n. 2, p. 65-71, 1 jan. 2012.

EKMEKYAPAR, F. et al. Biosorption of copper(II) by nonliving lichen biomass of Cladonia rangiformis hoffm. Journal of Hazardous Materials, v. 137, n. 1, p. 293-298, 1 set. 2006.

FARAHAT, M. et al. Adsorption of SIP E. coli onto quartz and its applications in froth flotation. Minerals Engineering, v. 21, n. 5, p. 389395, 1 abr. 2008. 
FARAHAT, M. et al. Adhesion of Escherichia coli onto quartz, hematite and corundum: Extended DLVO theory and flotation behavior. Colloids and Surfaces B: Biointerfaces, v. 74, n. 1, p. 140-149, 1 nov. 2009.

FAZAELIPOOR, M. H.; KHOSHDAST, H.; RANJBAR, M. Coal flotation using a biosurfactant from Pseudomonas aeruginosa as a frother. Korean Journal of Chemical Engineering, v. 27, n. 5, p. 1527-1531, 1 set. 2010.

FILIPPOV, L. O.; SEVEROV, V. V.; FILIPPOVA, I. V. An overview of the beneficiation of iron ores via reverse cationic flotation. International Journal of Mineral Processing, v. 127, p. 62-69, 10 mar. 2014.

FINNERTY, W. R. The biology and genetics of the genus Rhodococcus. Annual Reviews in Microbiology, v. 46, n. 1, p. 193-218, 1992.

FOOLADI, T. et al. Characterization, production and optimization of lipopeptide biosurfactant by new strain Bacillus pumilus 2IR isolated from an Iranian oil field. Journal of Petroleum Science and Engineering, v. 145, p. 510-519, 1 set. 2016.

FRANZETTI, A. et al. Production and applications of trehalose lipid biosurfactants. European Journal of Lipid Science and Technology, v. 112, n. 6, p. 617-627, 19 abr. 2010.

GARIP, S.; GOZEN, A. C.; SEVERCAN, F. Use of Fourier transform infrared spectroscopy for rapid comparative analysis of Bacillus and Micrococcus isolates. Food Chemistry, v. 113, n. 4, p. 1301-1307, 15 abr. 2009.

HACHA, R. R. Eletroflotação de partículas finas de hematita em célula modificada de Partridge-Smith usando Rhodococcus opacus como coletor. Tese de Doutorado apresentada como requisito parcial para obtenção do título de Doutor pelo Programa de Pós-Graduação em Engenharia de Materiais e de Processos Químicos e Metalúrgicos-Rio de Janeiro: PUC-Rio, 2016.

HAUSMANN, R.; SYLDATK, C. Types and Classification of Microbial Surfactants. In: BIOSURFACTANTS: Production and UtilizationProcesses, Technologies, and Economics. Surfactant Science. [s.I.] CRC Press, 2015.

HERNÁINZ, F.; CALERO, M. Froth flotation: kinetic models based on chemical analogy. Chemical Engineering and Processing: Process Intensification, v. 40, n. 3, p. 269-275, 1 maio 2001.

HERNÁINZ, F.; CALERO, M.; BLÁZQUEZ, G. Kinetic considerations in the flotation of phosphate ore. Advanced Powder Technology, v. 16, n. 4, p. 347-361, 1 jan. 2005.

HIRAJIMA, T. et al. Effect of microorganisms on flocculation of quartz. International Journal of Mineral Processing, v. 102, p. 107-111, 25 jan. 2012. 
HUANG, Z. et al. Investigations on reverse cationic flotation of iron ore by using a Gemini surfactant: Ethane-1,2-bis(dimethyl-dodecyl-ammonium bromide). Chemical Engineering Journal, v. 257, p. 218-228, 1 dez. 2014.

HUNTER, R. J. Zeta Potential in Colloid Science: Principles and Applications. [s.I.] Academic Press, 1981.

IGLESIAS, J. C. Á. Desenvolvimento de um sistema de miscroscopia digital para classificação automática de tipos de hematita em minério de ferro. Tese apresentada como requisito parcial para obtenção do título de Doutor pelo Programa de Pós-Graduação em Ingenieria dos Materiais e de Processos Químicos e Metalúrgicos-Rio de Janeiro: PUC-Rio, 2012.

JAJOR, P. et al. Surfactin analogues produced by Bacillus subtilis strains grown on rapeseed cake. Journal of Molecular Structure, From Molecules to Molecular Materials, Biological Molecular Systems and Nanostructures. v. 1126, p. 141-146, 15 dez. 2016.

JAMETT, N.; CISTERNAS, L. A.; VIELMA, J. P. Solution strategies to the stochastic design of mineral flotation plants. Chemical Engineering Science, v. 134, p. 850-860, 29 set. 2015.

JEFFERY, G. H. et al. Vogel's textbook of quantitative chemical analysis. 5th. ed. [s.I.] John Wiley \& Sons Inc, 1989.

JIANG, Y.-R. et al. Novel alkyl bis(hydroxycarbamoyl) propionic acids for flotation separation of diaspore against aluminosilicate minerals. Separation and Purification Technology, v. 87, p. 135-141, 5 mar. 2012.

JIN, J. et al. The separation of kyanite from quartz by flotation at acidic $\mathrm{pH}$. Minerals Engineering, v. 92, p. 221-228, 1 jun. 2016.

KHAN, M. S. A.; SINGH, B.; CAMEOTRA, S. S. Biological Applications of Biosurfactants and Strategies to Potentiate Commercial Production. In: BIOSURFACTANTS: Production and Utilization-Processes, Technologies, and Economics. Surfactant Science. [s.I.] CRC Press, 2015.

KHOSHDAST, $H$. et al. Effect of rhamnolipid biosurfactants on performance of coal and mineral flotation. International Biodeterioration \& Biodegradation, v. 65, n. 8, p. 1238-1243, 1 dez. 2011.

KHOSHDAST, H.; SAM, A.; MANAFI, Z. The use of rhamnolipid biosurfactants as a frothing agent and a sample copper ore response. Minerals Engineering, v. 26, p. 41-49, 1 jan. 2012.

$\mathrm{KIM}$, G. et al. Bioflotation of malachite using different growth phases of Rhodococcus opacus: Effect of bacterial shape on detachment by shear 
flow. International Journal of Mineral Processing, v. 143, p. 98-104, 10 out. 2015.

KUYUKINA, M. S. et al. Recovery of Rhodococcus biosurfactants using methyl tertiary-butyl ether extraction. Journal of Microbiological Methods, v. 46, n. 2, p. 149-156, 1 ago. 2001.

LANG, S.; PHILP, J. C. Surface-active lipids in rhodococci. Antonie van Leeuwenhoek, v. 74, n. 1-3, p. 59-70, 1 out. 1998.

LARSEN, E.; KLEIV, R. A. Towards a new process for the flotation of quartz. Minerals Engineering, v. 83, p. 13-18, 1 nov. 2015.

$\mathrm{LI}, \mathrm{X}$. et al. Flotation separation of quartz from collophane using an amine collector and its adsorption mechanisms. Powder Technology, v. 318, p. 224-229, ago. 2017.

LIU, B. et al. Purification and characterization of biosurfactant produced by Bacillus licheniformis Y-1 and its application in remediation of petroleum contaminated soil. Marine Pollution Bulletin, v. 107, n. 1, p. 46-51, 15 jun. 2016.

LIU, C.-W.; LIU, H.-S. Rhodococcus erythropolis strain NTU-1 efficiently degrades and traps diesel and crude oil in batch and fed-batch bioreactors. Process Biochemistry, v. 46, n. 1, p. 202-209, jan. 2011.

LIU, W. et al. Synergistic Adsorption of N-dodecyl Ethylenediamine Along with Polyethylene Glycol (PEG) on Quartz. INTERNATIONAL JOURNAL OF ELECTROCHEMICAL SCIENCE, v. 10, n. 11, p. 9310-9323, 2015.

LIU, W. et al. Synthesis of N,N-Bis(2-hydroxypropyl)laurylamine and its flotation on quartz. Chemical Engineering Journal, v. 309, p. 63-69, 1 fev. 2017.

LOPES, G. M.; LIMA, R. M. F. Flotação direta de minério de ferro com oleato de sódio. Rem: Revista Escola de Minas, v. 62, n. 3, p. 323-329, set. 2009.

LOPEZ, L. Y. et al. Fundamental aspects of hematite flotation using the bacterial strain Rhodococcus ruber as bioreagent. Minerals Engineering, Biohydrometallurgy. v. 75, p. 63-69, 1 maio 2015.

MA, M. Froth Flotation of Iron Ores. International Journal of Mining Engineering and Mineral Processing, v. 1, n. 2, p. 56-61, 31 ago. 2012.

MADIGAN, M. et al. Microbiologia De Brock. $12^{\mathrm{a}}$ edição, editora Artmed. Porto Alegre, 2010.

MARABINI, A. M. et al. Chelating reagents for flotation. Minerals Engineering, Selected papers from Reagents '06, Cape Town, South Africa, November 2006. v. 20, n. 10, p. 1014-1025, 1 ago. 2007. 
MARTÍNKOVÁ, L. et al. Biodegradation potential of the genus Rhodococcus. Environment International, v. 35, n. 1, p. 162-177, 1 jan. 2009.

MENDE, M. et al. Simultaneous adsorption of heavy metal ions and anions from aqueous solutions on chitosan-Investigated by spectrophotometry and SEM-EDX analysis. Colloids and Surfaces A: Physicochemical and Engineering Aspects, Selected papers from the 29th European Colloid and Interface Society conference (29th ECIS 2015). v. 510, p. 275-282, 5 dez. 2016.

MENEZES, C. T. B. et al. Replacing Synthetic with Microbial Surfactants as Collectors in the Treatment of Aqueous Effluent Produced by Acid Mine Drainage, Using the Dissolved Air Flotation Technique. Applied Biochemistry and Biotechnology, v. 163, n. 4, p. 540-546, fev. 2011.

MERMA, A. G. et al. On the fundamental aspects of apatite and quartz flotation using a Gram positive strain as a bioreagent. Minerals Engineering, Biohydrometallurgy. v. 48, p. 61-67, 1 jul. 2013.

MERMA, A. G.; TOREM, M. L. Bioflotation of apatite and quartz: Particle size effect on the rate constant. Rem: Revista Escola de Minas, v. 68, n. 3, p. 343-350, set. 2015.

MESQUITA, L. M. S.; LINS, F. F.; TOREM, M. L. Interaction of a hydrophobic bacterium strain in a hematite-quartz flotation system. International Journal of Mineral Processing, v. 71, n. 1, p. 31-44, 22 set. 2003.

MOHAMMADNEJAD, S.; PROVIS, J. L.; VAN DEVENTER, J. S. J. Effects of grinding on the preg-robbing potential of quartz in an acidic chloride medium. Minerals Engineering, Process Mineralogy. v. 52, p. 31-37, 1 out. 2013.

MONTE, M. B. DE M.; PERES, A. E. C. Química de Superfície na Flotação. In: Tratamento de Minérios. 5. ed. Rio de Janeiro: Centro de Tecnologia Mineral (CETEM)/Ministério da Ciência e Tecnologia (MCT), 2010. p. 965.

MOREAU, R. A.; POWELL, M. J.; SINGH, V. Pressurized liquid extraction of polar and nonpolar lipids in corn and oats with hexane, methylene chloride, isopropanol, and ethanol. Journal of the American Oil Chemists' Society, v. 80, n. 11, p. 1063-1067, 2003.

MOUSSA, Z.; CHEBL, M.; PATRA, D. Interaction of curcumin with 1,2dioctadecanoyl-sn-glycero-3-phosphocholine liposomes: Intercalation of rhamnolipids enhances membrane fluidity, permeability and stability of drug molecule. Colloids and Surfaces B: Biointerfaces, v. 149, p. 3037, 1 jan. 2017.

MUKHERJEE, A. K.; DAS, K. Microbial Surfactants and Their Potential Applications: An Overview. In: Biosurfactants. ADVANCES IN 
EXPERIMENTAL MEDICINE AND BIOLOGY. [s.I.] Springer Science \& Business Media, 2010.

MULLIGAN, C. N. Environmental applications for biosurfactants. Environmental Pollution, v. 133, n. 2, p. 183-198, 1 jan. 2005.

MULLIGAN, C. N. et al. Green Chemistry and Biosurfactant Research. In: Biosurfactants: Research Trends and Applications. [s.I.] CRC Press, 2014.

NAGARAJ, D. R. Reagent selection and optimization-the case for a holistic approach. Minerals Engineering, Reagents '04. v. 18, n. 2, p. 151-158, 1 fev. 2005.

NAJA, G.; VOLESKY, B. The Mechanism of Metal Cation and Anion Biosorption. In: KOTRBA, P.; MACKOVA, M.; MACEK, T. (Eds.). . Microbial Biosorption of Metals. [s.I.] Springer Netherlands, 2011. p. $19-58$.

NITSCHKE, M.; PASTORE, G. M. Biosurfactants: properties and applications. Química Nova, v. 25, n. 5, p. 772-776, set. 2002.

OLIVEIRA, A. C. DOS S. M. Recuperação e Purificação de Ramnolipídeos produzidos por Pseudomonas aeruginosa P029GVIIA utilizando Melaço de Cana como substrato. Tese apresentada ao programa de pós-graduação em engenharia química como parte dos requisitos para obtenção do grau de doutora—Natal: UFRN, 2010.

OLIVERA, C. A. C. Bioflotação da hematita usando a bactéria Rhodococcus erythropolis. Dissertação de Mestrado apresentada como requisito parcial para obtenção do título de Mestre pelo Programa de PósGraduação em Engenharia de Materiais e de Processos Químicos e Metalúrgicos-Rio de Janeiro: PUC-Rio, 2014.

OLIVERA, C. A. C. et al. On the fundamentals aspects of hematite bioflotation using a Gram positive strain. Minerals Engineering, Biohydrometallurgy. v. 106, p. 55-63, 15 maio 2017.

PACHECO, G. J. Produção de biossurfactantes por Rhodococcus erythropolis e sua aplicação na remoção de óleo de sedimentos arenosos. Dissertação apresentada ao curso de Pós-graduação em Tecnologia de Processos Químicos e Bioquímicos para a obtenção do Grau de Mestre em Ciências-Rio de Janeiro: UFRJ, 2008.

PACWA-PŁOCINICZAK, $M$. et al. Environmental Applications of Biosurfactants: Recent Advances. International Journal of Molecular Sciences, v. 12, n. 1, p. 633-654, 18 jan. 2011.

PADUKONE, S. U.; NATARAJAN, K. A. Microbially induced separation of quartz from calcite using Saccharomyces cerevisiae. Colloids and Surfaces B: Biointerfaces, v. 88, n. 1, p. 45-50, 1 nov. 2011. 
PATRA, P.; NATARAJAN, K. A. Role of mineral specific bacterial proteins in selective flocculation and flotation. International Journal of Mineral Processing, v. 88, n. 1, p. 53-58, 1 ago. 2008.

PAVLOVIC, S.; BRANDAO, P. R. G. Adsorption of starch, amylose, amylopectin and glucose monomer and their effect on the flotation of hematite and quartz. Minerals Engineering, Froth Flotation. v. 16, n. 11, p. 1117-1122, 1 nov. 2003.

PEÇANHA, E. R. Bioflotação Seletiva de Hematita em relação ao Quartzo: Cálculo da Energia de Superfície e da Adesão do Bacillus subtilis. Dissertação de Mestrado apresentada como requisito parcial para obtenção do título de Mestre pelo Programa de Pós-Graduação em Engenharia de Materiais e de Processos Químicos e Metalúrgicos-Rio de Janeiro: PUC-Rio, 2014.

POORTINGA, A. T. et al. Electric double layer interactions in bacterial adhesion to surfaces. Surface Science Reports, v. 47, n. 1, p. 1-32, 1 jun. 2002.

PORNSUNTHORNTAWEE, $O$. et al. Biosurfactant production by Pseudomonas aeruginosa SP4 using sequencing batch reactors: Effects of oil loading rate and cycle time. Bioresource Technology, v. 100, n. 2, p. 812-818, 1 jan. 2009.

QUAST, K. Effects of solution ageing on the zeta potential characteristics of a hematite ore. Advanced Powder Technology, v. 26, n. 4, p. 12191224, 1 jul. 2015.

RAICHUR, A. M. et al. Flocculation and flotation of coal by adhesion of hydrophobic Mycobacterium phlei. Colloids and Surfaces B: Biointerfaces, v. 8, n. 1, p. 13-24, 10 dez. 1996.

SABARI PRAKASAN, M. R.; NATARAJAN, K. A. Microbially induced separation of quartz from hematite using sulfate reducing bacteria. Colloids and Surfaces B: Biointerfaces, v. 78, n. 2, p. 163-170, 1 jul. 2010.

$\mathrm{SAHOO}, \mathrm{H}$. et al. Role of silica and alumina content in the flotation of iron ores. International Journal of Mineral Processing, v. 148, p. 83-91, 10 mar. 2016a.

$\mathrm{SAHOO}, \mathrm{H}$. et al. Flotation of quartz using ionic liquid collectors with different functional groups and varying chain lengths. Minerals Engineering, v. 95, p. 107-112, 1 set. 2016b.

SAIEN, J.; BAHRAMI, M. Understanding the effect of different size silica nanoparticles and SDS surfactant mixtures on interfacial tension of $n$ hexane-water. Journal of Molecular Liquids, v. 224, p. 158-164, 1 dez. 2016. 
SALAGER, J.-L. Surfactants types and uses. Firp Booklet, n. E300A, 2002.

SANTOS, M. A. A flotação por ar dissolvido como alternativa ao tratamento de efluente mineral visando ao reuso da água e à melhoria do processo de flotação de apatita. Tese de Doutorado apresentada como parte dos requisitos necessários à obtenção do título de Doutor em Engenharia Química-Minas Gerais: Universidade Federal de Uberlândia, 2014.

SANWANI, E. et al. Bioflotation: Bacteria-Mineral Interaction for Ecofriendly and Sustainable Mineral Processing. Procedia Chemistry, 5th International Conference on Recent Advances in Materials, Minerals and Environment (RAMM) \& 2nd International Postgraduate Conference on Materials, Mineral and Polymer (MAMIP). v. 19, p. 666-672, 1 jan. 2016.

SARVAMANGALA, $\mathrm{H}$. et al. Biobeneficiation of Iron Ores. International Journal of Mining Engineering and Mineral Processing, v. 1, n. 2, p. 21-30, 2012.

SARVAMANGALA, H.; NATARAJAN, K. A. Microbially induced flotation of alumina, silica/calcite from haematite. International Journal of Mineral Processing, v. 99, n. 1, p. 70-77, 8 maio 2011.

SHARMA, P. K. Surface studies relevant to microbial adhesion and bioflotation of sulphide minerals. 2001.

SHARMA, P. K. et al. Surface chemical characterisation of Paenibacillus polymyxa before and after adaptation to sulfide minerals. International Journal of Mineral Processing, Minerals Bioprocessing IV. v. 62, n. 1, p. 3-25, 1 maio 2001.

SHARMA, P. K.; HANUMANTHA RAO, K. Analysis of different approaches for evaluation of surface energy of microbial cells by contact angle goniometry. Advances in Colloid and Interface Science, v. 98, n. 3, p. 341-463, 5 ago. 2002.

SHARMA, P. K.; HANUMANTHA RAO, K. Adhesion of Paenibacillus polymyxa on chalcopyrite and pyrite: surface thermodynamics and extended DLVO theory. Colloids and Surfaces B: Biointerfaces, v. 29, n. 1 , p. 21-38, 15 maio 2003.

SHASHIKALA, A. R.; RAICHUR, A. M. Role of interfacial phenomena in determining adsorption of Bacillus polymyxa onto hematite and quartz. Colloids and Surfaces B: Biointerfaces, v. 24, n. 1, p. 11-20, 1 mar. 2002.

SILVA, J. P. P. Mecanismo de ação do silicato de sódio como depressor em flotação. Dissertação Apresentada ao Programa de PósGraduação em Engenharia Mineral para a Obtenção do Grau de MestreRecife: UFPE, 2011. 
SINGH, V. et al. Application of quartz inversion phenomenon in mineral processing - A case study of siliceous manganese ores. Minerals Engineering, v. 32, p. 8-11, 1 maio 2012.

STICKLAND, L. H. The determination of small quantities of bacteria by means of the biuret reaction. Microbiology, v. 5, n. 4, p. 698-703, 1951.

SUBRAMANIAN, S.; SANTHIYA, D.; NATARAJAN, K. A. Surface modification studies on sulphide minerals using bioreagents. International Journal of Mineral Processing, Special Issue To Honor Professor Douglas W. Fuerstenau. v. 72, n. 1, p. 175-188, 29 set. 2003.

TADROS, T. F. An introduction to surfactants. [s.I.] Walter de Gruyter, 2014.

TALARO, K. P.; CHESS, B. Foundations in Microbiology. 10th. ed. [s.I.] McGraw-Hill Education, 2017.

VAN DER WAL, A. et al. Determination of the total charge in the cell walls of Gram-positive bacteria. Colloids and Surfaces B: Biointerfaces, v. 9, n. 1, p. 81-100, 10 jun. 1997.

VECINO, X. et al. Evaluation of biosurfactant obtained from Lactobacillus pentosus as foaming agent in froth flotation. Journal of Environmental Management, v. 128, p. 655-660, 15 out. 2013.

VILINSKA, A.; RAO, K. H. Leptosririllum ferrooxidans-sulfide mineral interactions with reference to bioflotation nad bioflocculation. Transactions of Nonferrous Metals Society of China, v. 18, n. 6, p. 1403-1409, 1 dez. 2008.

WALTER, V.; CHRISTOPH, S.; RUDOLF, H. Screening Concepts for the Isolation of Biosurfactant Producing Microorganisms. In: Biosurfactants. ADVANCES IN EXPERIMENTAL MEDICINE AND BIOLOGY. [s.I.] Springer Science \& Business Media, 2010.

WENGANG, L. et al. Adsorption mechanism of N-laurel-1,3diaminopropane in a hematite-quartz flotation system. Mining Science and Technology (China), v. 21, n. 2, p. 213-215, 1 mar. 2011.

WHYTE, L. G. et al. Prevalence of alkane monooxygenase genes in Arctic and Antarctic hydrocarbon-contaminated and pristine soils1. FEMS Microbiology Ecology, v. 41, n. 2, p. 141-150, 1 ago. 2002.

WILLS, B. A.; FINCH, J. Wills' mineral processing technology: an introduction to the practical aspects of ore treatment and mineral recovery. [s.l.] Butterworth-Heinemann, 2015.

XIA, W.-J. et al. Comparative study of biosurfactant produced by microorganisms isolated from formation water of petroleum reservoir. Colloids and Surfaces A: Physicochemical and Engineering Aspects, v. 392, n. 1, p. 124-130, 5 dez. 2011. 
YALCIN, E.; KELEBEK, S. Flotation kinetics of a pyritic gold ore. International Journal of Mineral Processing, v. 98, n. 1, p. 48-54, 17 jan. 2011.

YANG, $\mathrm{H}$. et al. Flocculation and flotation response of Rhodococcus erythropolis to pure minerals in hematite ores. Minerals Engineering, $v$. 45 , p. $67-72,1$ maio $2013 a$.

YANG, $\mathrm{H}$. et al. Development of a bio-based collector by isolating a bacterial strain using flotation and culturing techniques. International Journal of Mineral Processing, v. 123, p. 145-151, 10 set. 2013b.

YANG, $\mathrm{H}$. et al. Possibility of using strain F9 (Serratia marcescens) as a bio-collector for hematite flotation. International Journal of Minerals, Metallurgy, and Materials, v. 21, n. 3, p. 210-215, 1 mar. 2014a.

YANG, H.; ZHANG, Q.; JIANG, Z. Adsorbability of Mycobacterium phlei on hematite surface. Journal of University of Science and Technology Beijing, Mineral, Metallurgy, Material, v. 14, n. 2, p. 103-106, 1 abr. 2007.

YANG, Z. et al. Effect of biological pretreatment on flotation recovery of pyrolusite. Transactions of Nonferrous Metals Society of China, v. 24, n. 5, p. 1571-1577, 1 maio 2014b.

YEMM, E. W.; WILLIS, A. J. The estimation of carbohydrates in plant extracts by anthrone. Biochemical Journal, v. 57, n. 3, p. 508-514, jul. 1954.

ZHOU, F. et al. Reactive oily bubble technology for flotation of apatite, dolomite and quartz. International Journal of Mineral Processing, v. 134, p. 74-81, 10 jan. 2015.

ZOUBOULIS, A. I. et al. The use of biosurfactants in flotation: application for the removal of metal ions. Minerals Engineering, Froth Flotation. v. 16, n. 11, p. 1231-1236, 1 nov. 2003. 


\section{8 Apêndices}

Apêndice 1. Metodologia experimental da extração do biossurfactante

\section{Metodologia experimental para a obtenção da biomassa e a extração do biossurfactante}

\section{Introdução:}

Os biossurfactantes são compostos ativos em superfícies produzidos por microrganismos. Com o desenvolvimento da biotecnologia nos últimos anos, tem-se verificado que os microrganismos e seus produtos metabólicos podem agir como biorreagentes que poderiam cumprir as mesmas funções dos reagentes convencionais de beneficiamento mineral. Dessa forma, o uso de biossurfactantes como reagentes representa uma alternativa promissora aos surfatantes sintéticos utilizados na indústria mineral, devido à sua baixa toxicidade e natureza biodegradável.

\section{Objetivo:}

- O presente documento tem como principal objetivo apresentar de forma clara e em detalhe o passo a passo para a produção do biossurfactante extraído da bactéria Rhodococcus Erythropolis e Rhodococcus opacus.

- Atender os regulamentos e requerimentos do grupo de pesquisa em tecnologia mineral e ambiental (GPTMA) do Departamento de Engenharia Química e de Materiais (DEQM) da PUC-Rio. 


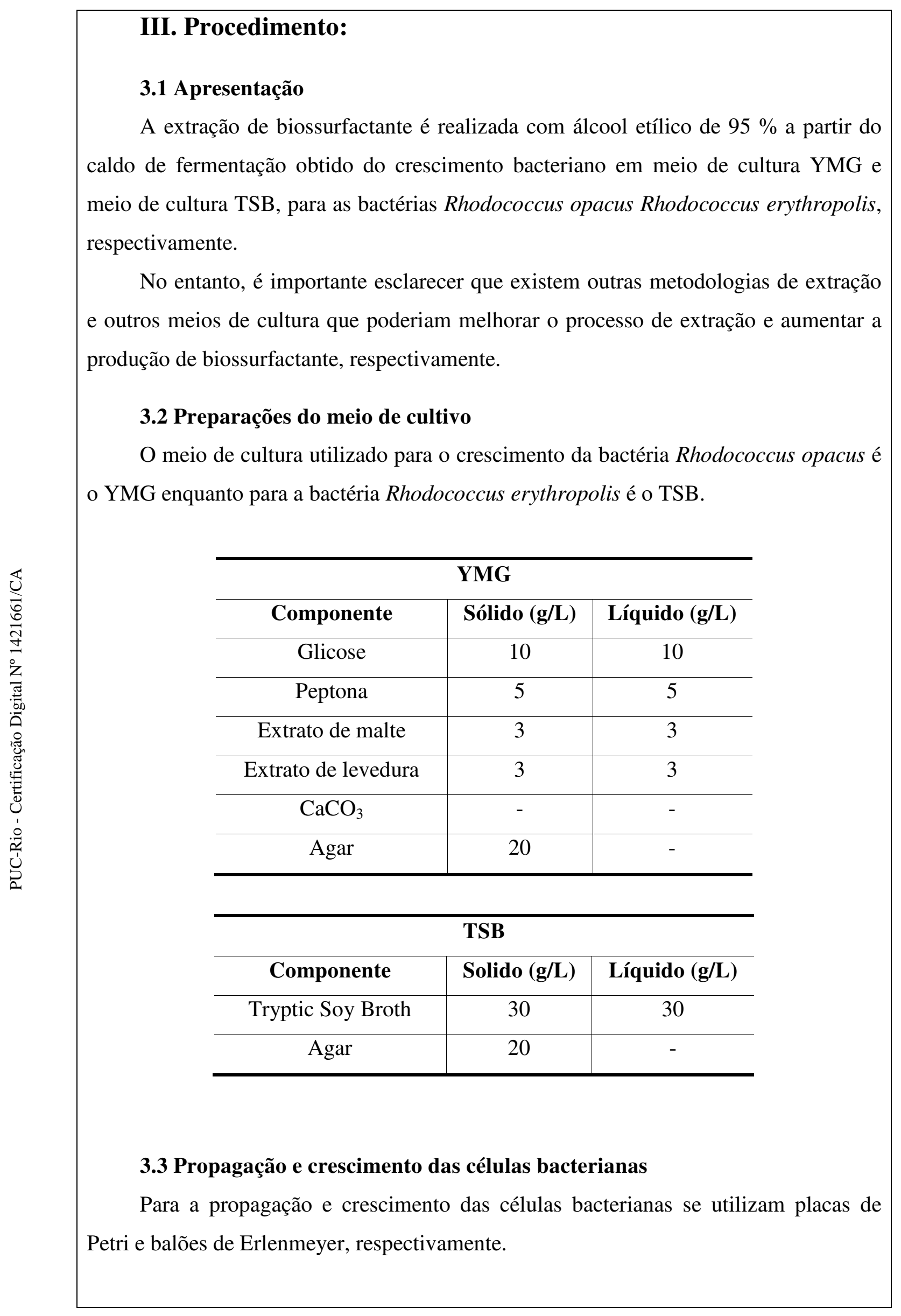




\subsubsection{Em meio sólido}

a. Utiliza-se balão de Erlenmeyer de $250 \mathrm{ml}$, e a quantidade de solução a preparar depende do numero de placas de Petri a usar, sabendo-se como referencia que em cada placa de Petri é esvaziado $20 \mathrm{ml}$ de solução.

b. Os balões de Erlenmeyer (com solução) devidamente fechados com tampões de algodão e bonés feitos de papel kraft, junto com as placas de Petri também forradas com papel kraft, são colocados dentro do autoclave (ver procedimento de manipulação da autoclave) para ser submetidos a um processo de esterilização mediante calor úmido (autoclavação), a 1,1 atm de pressão durante $20 \mathrm{~min}$.

c. Retirar o material da autoclave e esfriar por 5 minutos para depois ser levados para a capela (ver procedimento de manipulação da capela) devidamente esterilizada, onde a solução será esvaziada dentro das placas de Petri antes que ela comece a solidificar.

d. As placas de Petri com o meio de cultivo solidificado são levadas ao fogo lento para consumir o vapor úmido gerado durante a solidificação.

e. Posteriormente é realizado o processo de inoculação a partir dos slants (gelose inclinada) ou outras placas, utilizando uma alça de platina esterilizada ao fogo lento. Após disso, as placas de Petri são fechadas com parafilme e deixadas em um lugar isolado e seguro à temperatura ambiente para evidenciar seu crescimento.

f. O crescimento das células bacterianas nas placas de Petri será evidente a partir das 24 horas e, após de transcorrer dois dias, estas serão guardadas na geladeira a $4^{\circ} \mathrm{C}$ para inibir seu crescimento.

\subsubsection{Em meio líquido}

a. Utilizam-se balões de Erlenmeyer de $500 \mathrm{ml}$, e a quantidade de solução a preparar depende do numero de balões a usar, sabendo-se como referencia que em cada balão serão vertidos $125 \mathrm{ml}$ de solução (ou seja, o $20 \%$ do volume total). Para ter um crescimento bacteriano homogêneo para a extração de biossurfactante, recomenda-se cultivar em dois Erlenmeyer e após de transcorrer 48 horas será propagado para o numero de Erlenmeyer que quiser cultivar. 
b. Os dois balões de Erlenmeyer (com solução) devidamente fechados com tampões de algodão e bonés feitos de papel kraft são colocados dentro do autoclave (ver procedimento de manipulação da autoclave) para ser submetidos a um processo de esterilização mediante calor úmido (autoclavação), a 1,1 atm de pressão durante 20 min.

c. Retirar o material da autoclave e deixar esfriar para depois ser levados para a capela (ver procedimento de manipulação da capela) devidamente esterilizada.

d. Posteriormente é realizado o processo de inoculação a partir de uma placa de Petri, utilizando uma alça de platina esterilizada ao fogo lento. Após disso, os dois balões de Erlenmeyer são deixados no shaker rotatório durante 48 horas, a uma temperatura de $28^{\circ} \mathrm{C}$ e $150 \mathrm{rpm}$.

e. Transcorridas às 48 horas de crescimento bacteriano, os dois balões de Erlenmeyer são levados para a capela (ver procedimento de manipulação da capela) devidamente esterilizada. Esse caldo de fermentação servirá para inocular o numero de Erlenmeyer preparados (seguirão o item a, b e c do cultivo em meio líquido).

f. A inoculação é feita utilizando uma pipeta de Pasteur devidamente esterilizada e a quantidade de solução a inocular é variável (1,5 ml para cada Erlenmeyer).

g. Depois de realizar a inoculação, os balões de Erlenmeyer são deixados no shaker rotatório durante 6 dias, a uma temperatura de $28^{\circ} \mathrm{C}$ e $150 \mathrm{rpm}$.

\subsection{Obtenções da biomassa}

A biomassa é obtida a partir do quarto 4 dia do crescimento bacteriano (usado para bioflotação, bioadesão e biocaptação), mas para a extração do biossurfactante recomenda-se no sexto dia. Sua obtenção é realizada por centrifugação (ver procedimento de manipulação da centrifuga). Veja o procedimento a seguir:

a. Utilizam-se tubos Falcon de $50 \mathrm{ml}$, e o processo de separação é realizada entre 4000 - $5000 \mathrm{rpm}$ durante 8 minutos.

b. O precipitado da centrifugação constituído pelas células bacterianas é desprendido utilizando um agitador e é ressuspenso em água deionizada para ser centrifugado mais uma vez. Este processo é realizado dois ou três vezes até liberar o meio de cultura. 
c. A biomassa obtida é diluída em água deionizada (ou em solução de eletrólito indiferente $10^{-3} \mathrm{~mol} / \mathrm{L}$ de $\mathrm{NaCl}$ para melhorar sua conservação) e é vertida em frasco de vidro para logo ser colocado dentro do autoclave (ver procedimento de manipulação da autoclave) para ser submetido a um processo de esterilização mediante calor úmido (autoclavação), a 1,1 atm de pressão durante $20 \mathrm{~min}$.

d. Posteriormente, o frasco de vidro contendo a biomassa é esfriado para determinar sua concentração utilizando um filtro de membrana millipore ou cadinhos de porcelana.

e. Depois de determinar a concentração, o frasco de vidro contendo a biomassa é guardado na geladeira a $4^{\circ} \mathrm{C}$ para futuros ensaios experimentais.

\subsection{Extração do biossurfactante}

Segue-se o mesmo procedimento experimental detalhado anteriormente até o processo de centrifugação. Com diferencia do primeiro, o procedimento é como segue:

a. O processo de centrifugação é realizado a $5000 \mathrm{rpm}$ durante 8 minutos, utilizando-se tubos Falcon de $50 \mathrm{ml}$.

b. O precipitado da centrifugação constituído pelas células bacterianas é desprendido utilizando um agitador e é ressuspenso em água deionizada para ser centrifugado mais uma vez. Este processo é realizado até liberar o meio de cultura.

c. A biomassa obtida é ressuspenso em álcool etílico de 95\%. Esta ressuspensão é referenciada na quantidade de meio de cultura que foi preparado, ou seja, para a quantidade de biomassa obtida a partir de $1000 \mathrm{ml}$ de caldo fermentação vamos utilizar $100 \mathrm{ml}$ de álcool (proporção 10:1).

f. O frasco com biomassa ressuspenso em álcool etílico de $95 \%$ é colocado dentro do autoclave (ver procedimento de manipulação da autoclave) para ser submetido a um processo de esterilização mediante calor úmido (autoclavação), a 1,1 atm de pressão durante $20 \mathrm{~min}$.

d. Logo, a solução esfriada é centrifugada a $5000 \mathrm{rpm}$ durante 10 minutos. O precipitado é descartado e, a solução sobrenadante é vertida em copos de Becker para ser submetida ao processo de evaporação numa estufa a $50{ }^{\circ} \mathrm{C}$ por 30 horas. 
e. Posteriormente, o precipitado obtido é o biossurfatante bruto. Esse biossurfatante é pesado e diluído em água deionizada (usam-se copos de Becker para diluir o BS bruto) para separar a parte solúvel pelo processo de centrifugação a $5000 \mathrm{rpm}$ durante 10 minutos. A parte insolúvel (precipitado) é descartada e a parte solúvel (sobrenadante) é filtrada para assegurar a remoção dos compostos insolúveis e impurezas remanescentes na solução.

f. Finalmente, a concentração da solução obtida é calculada pela diferencia do peso imerso em água deionizada (usa-se balão volumétrico para avolumar a solução). Logo após os cálculos, o biorreagente (solução de BS contida em um balão volumétrico) é guardado na geladeira a $4{ }^{\circ} \mathrm{C}$ para futuros ensaios experimentais. 
Apêndice 2. Curvas padrão

Apêndice 2.1. Curva padrão de proteínas

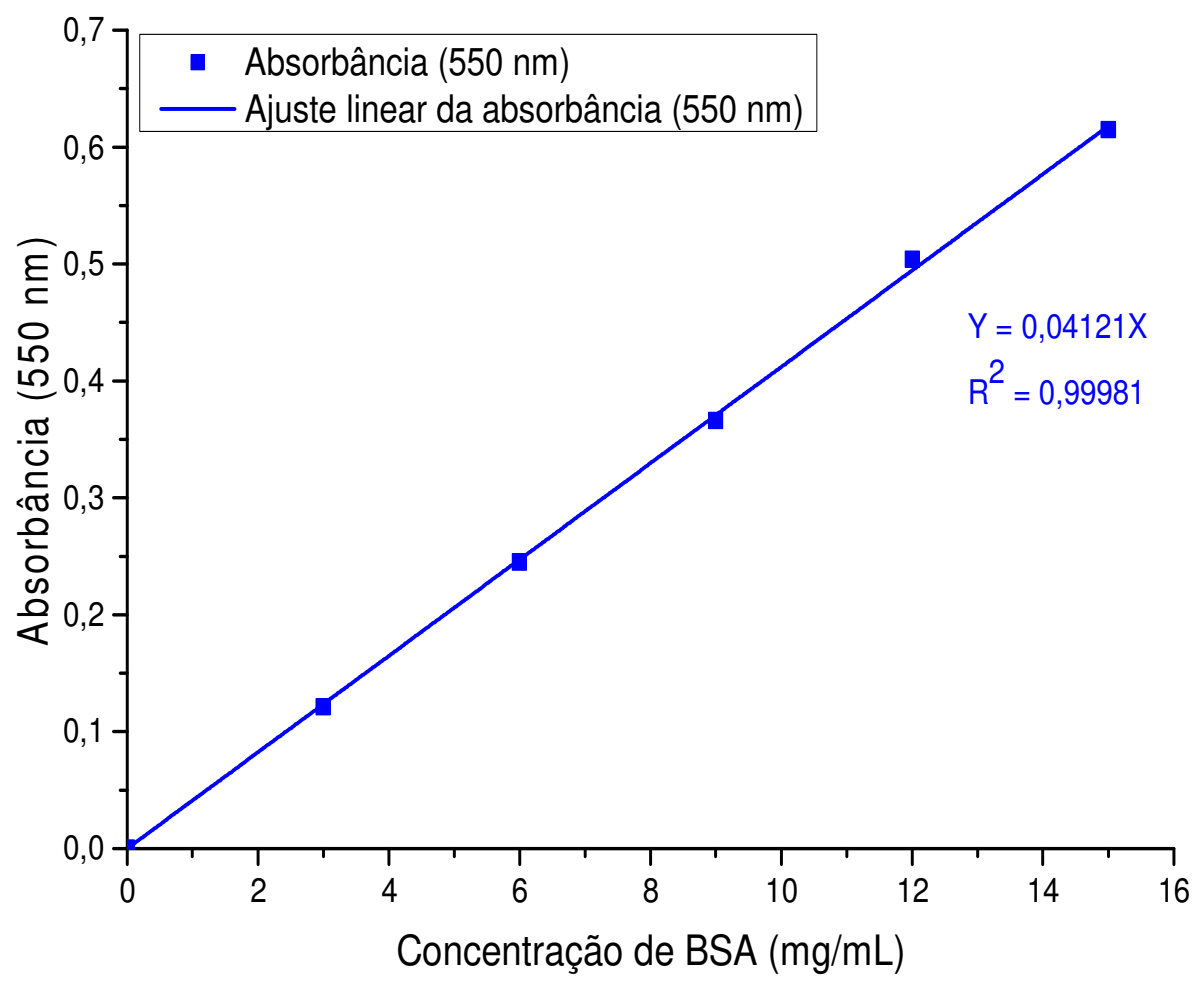

Figura 54. Curva padrão de proteínas 
Apêndice 2.2. Curva padrão de carboidratos

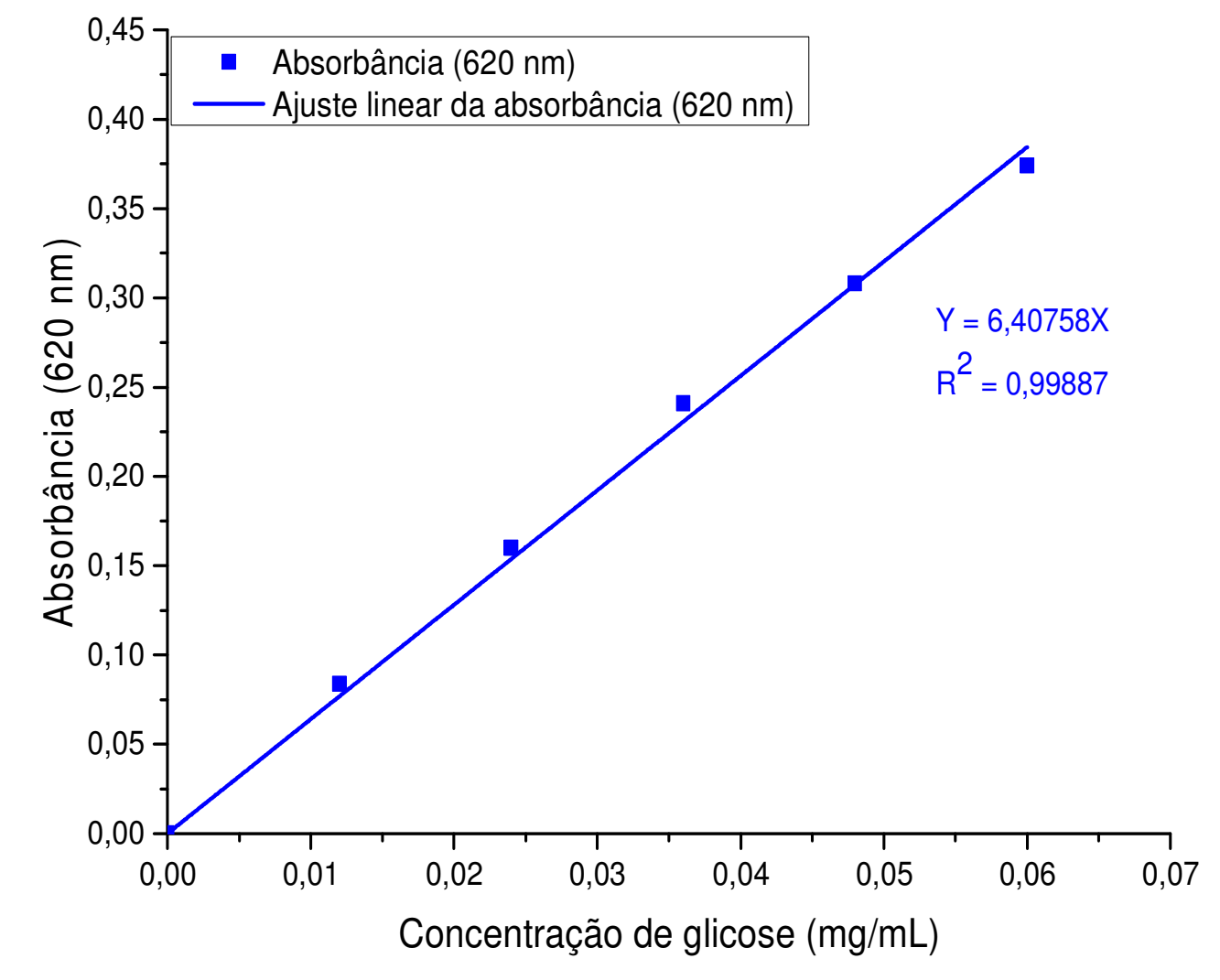

Figura 55. Curva padrão de carboidratos 
Apêndice 2.3. Curva padrão do biossurfactante

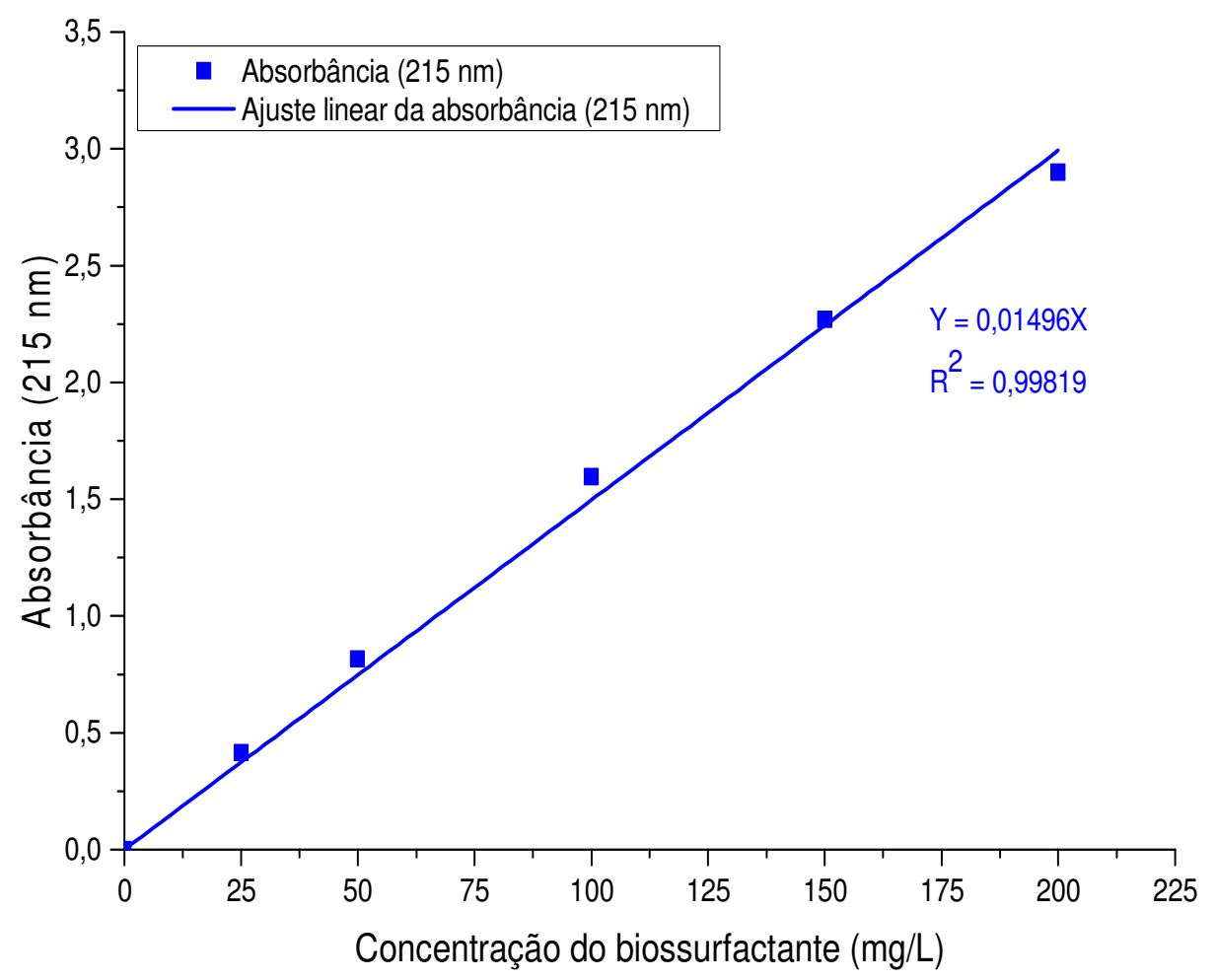

Figura 56. Curva padrão do biossurfactante 


\section{Metodologia experimental da análise química do ferro total por volumetria de oxirredução, utilizando o método de dicromatometria}

\section{Reagentes Necessários:}

a) Ácido Clorídrico P.A. ( $\mathrm{HCl})$.

b) Cloreto estanhoso a $10 \%$ - pesar $2,5 \mathrm{~g}$ e dissolver em $30 \mathrm{~mL}$ de ácido clorídrico. Após dissolução adicionar mais de $20 \mathrm{~mL}$ de água deionizada.

c) Cloreto de mercúrio a $5 \%\left(\mathrm{HgCl}_{2}\right)$ - pesar $5 \mathrm{~g}$ e dissolver em $100 \mathrm{~mL}$ de água deionizada.

d) Solução sulfo-fosfórica - $300 \mathrm{~mL}$ de água deionizada, $300 \mathrm{~mL}$ de $\mathrm{H}_{2} \mathrm{SO}_{4} \mathrm{e}$ $300 \mathrm{~mL}$ de $\mathrm{H}_{3} \mathrm{PO}_{4}$. Adicionar o $\mathrm{H}_{2} \mathrm{SO}_{4}$ lentamente na água, esperar a esfriar e adicionar o $\mathrm{H}_{3} \mathrm{PO}_{4}$.

e) Solução indicadora - pesar $0,1 \mathrm{~g}$ de difenilamino sulfonato de sódio em $100 \mathrm{~mL}$ de água.

f) Solução de $\mathrm{K}_{2} \mathrm{Cr}_{2} \mathrm{O}_{7}$ 0,1N - secar o dicromato de potássio a 140-150C por 1 hora. Pesar exatamente 4,904g e dissolver com água em balão volumétrico de 1 litro.

II. Procedimentos de análise:

a) Pesar 0,25g de amostra e transferir para Erlenmeyer de $500 \mathrm{~mL}$ contendo um pouco de água $(5-10 \mathrm{~mL})$.

b) Adicionar $20 \mathrm{~mL}$ de $\mathrm{HCl}$ e 3 gotas de solução de cloreto estanhoso $10 \%$.

c) Aquecer em chapa branda (80-90C) até a decomposição total da amostra.

d) Retirar da chapa e, adicionar em agitação constante, gota a gota de solução de cloreto estanhoso até o desaparecimento da coloração amarelada. Adicionar uma gota em excesso.

e) Lavar as paredes do Erlenmeyer com água fria até $\pm 50 \mathrm{~mL}$. 
f) Resfriar em água corrente até temperatura ambiente e então adicionar $10 \mathrm{~mL}$ de solução de cloreto mercúrico $5 \%$, agitar brandamente e deixar em repouso por 5 minutos.

g) Diluir com água fria até $\pm 200 \mathrm{~mL}$.

h) Adicionar $15 \mathrm{~mL}$ de solução sulfo-fosfórica.

i) Adicionar 3 gotas de solução indicadora.

j) Titular com solução de $\mathrm{K}_{2} \mathrm{Cr}_{2} \mathrm{O}_{7} 0,1 \mathrm{~N}$ até viragem da cor verde para violeta.

III. Cálculo do percentagem do ferro total:

$$
\% \mathrm{Fe}_{\text {Total }}=\left(\frac{\text { Volume } \mathrm{K}_{2} \mathrm{Cr}_{2} \mathrm{O}_{7} * 0.1 * 0.055845 * 100}{\text { Peso da amostra }}\right)
$$


Apêndice 4. Ajustes lineares da cinética de microflotação

Apêndice 4.1. Ajuste linear da cinética de microflotação de hematita usando o modelo de segunda ordem

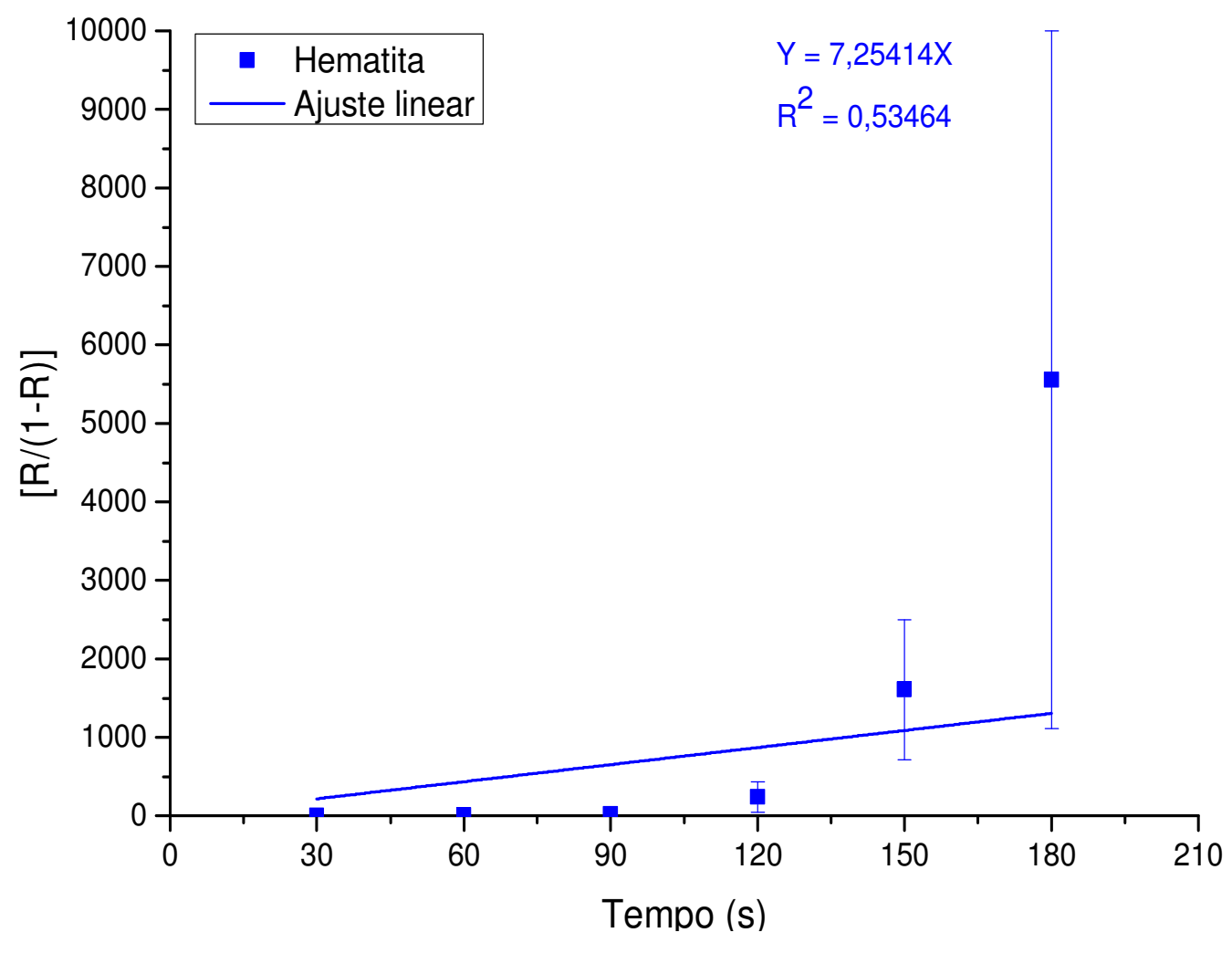

Figura 57. Ajuste linear da cinética de microflotação de hematita usando o modelo de segunda ordem 
Apêndice 4.2. Ajuste linear da cinética de microflotação de quartzo usando o modelo de primeira ordem

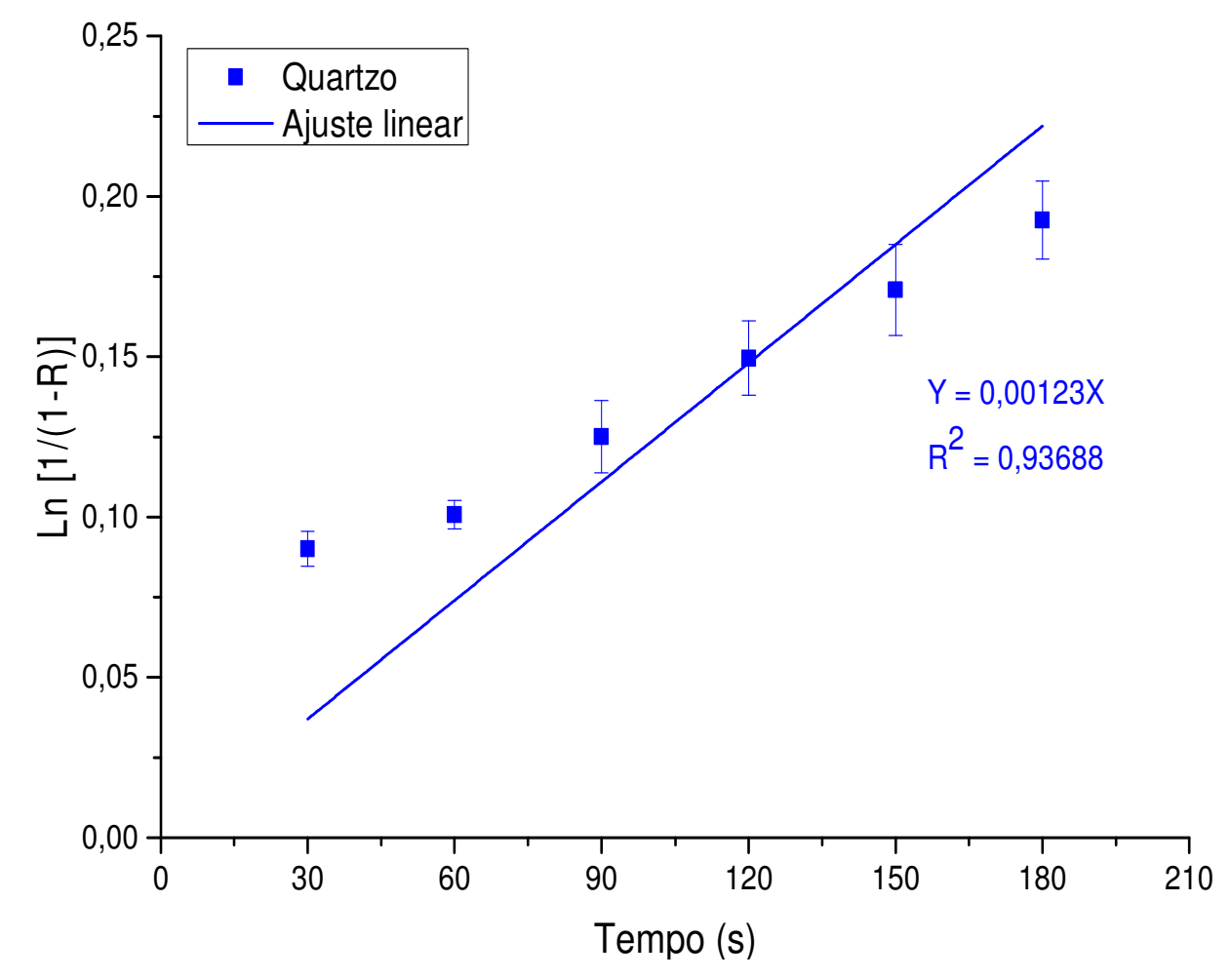

Figura 58. Ajuste linear da cinética de microflotação de quartzo usando o modelo de primeira ordem 
Apêndice 4.3. Ajuste linear da cinética de microflotação de quartzo usando o modelo de segunda ordem

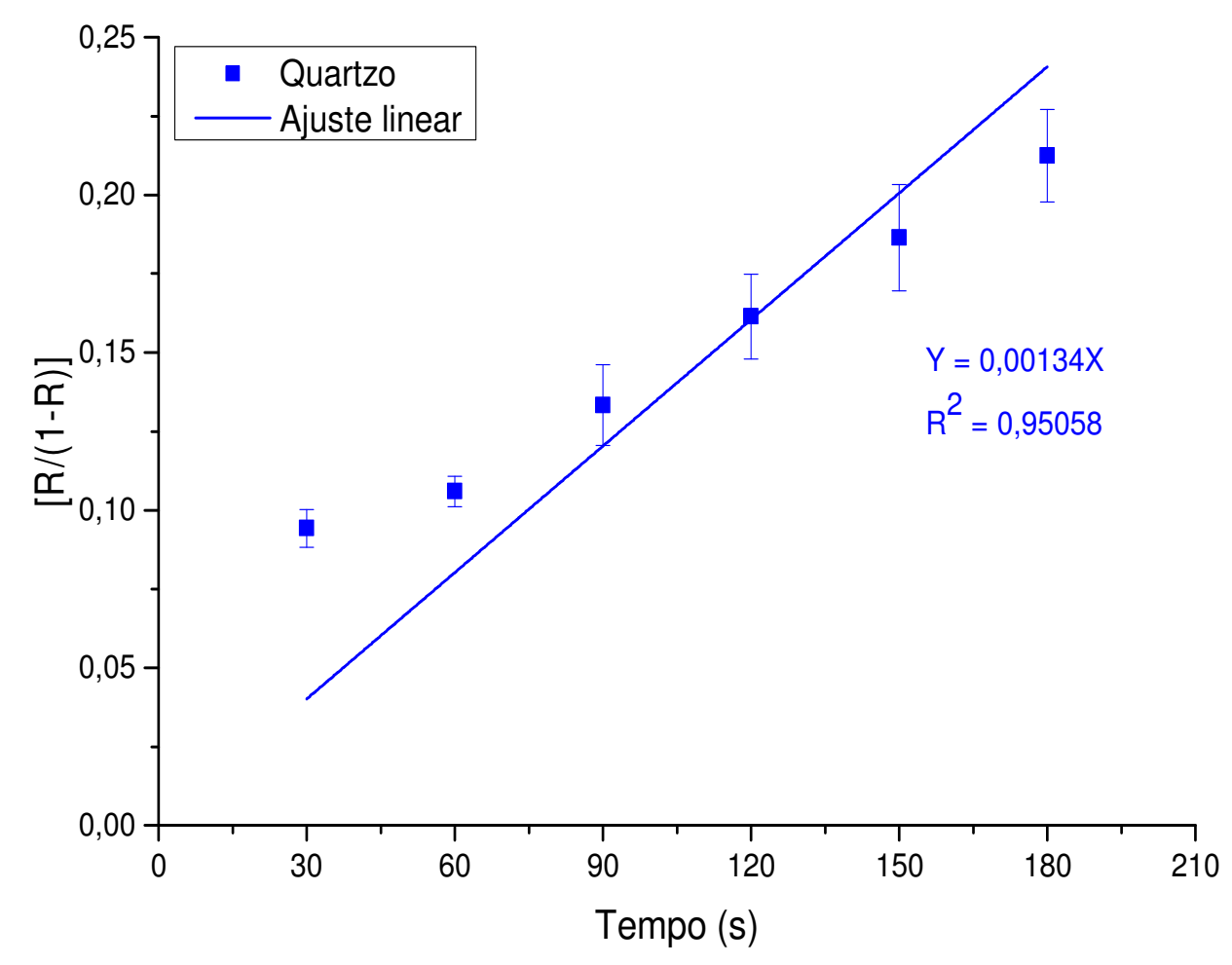

Figura 59. Ajuste linear da cinética de microflotação de quartzo usando o modelo de segunda ordem 